DIW BERLIN

Discussion

Papers
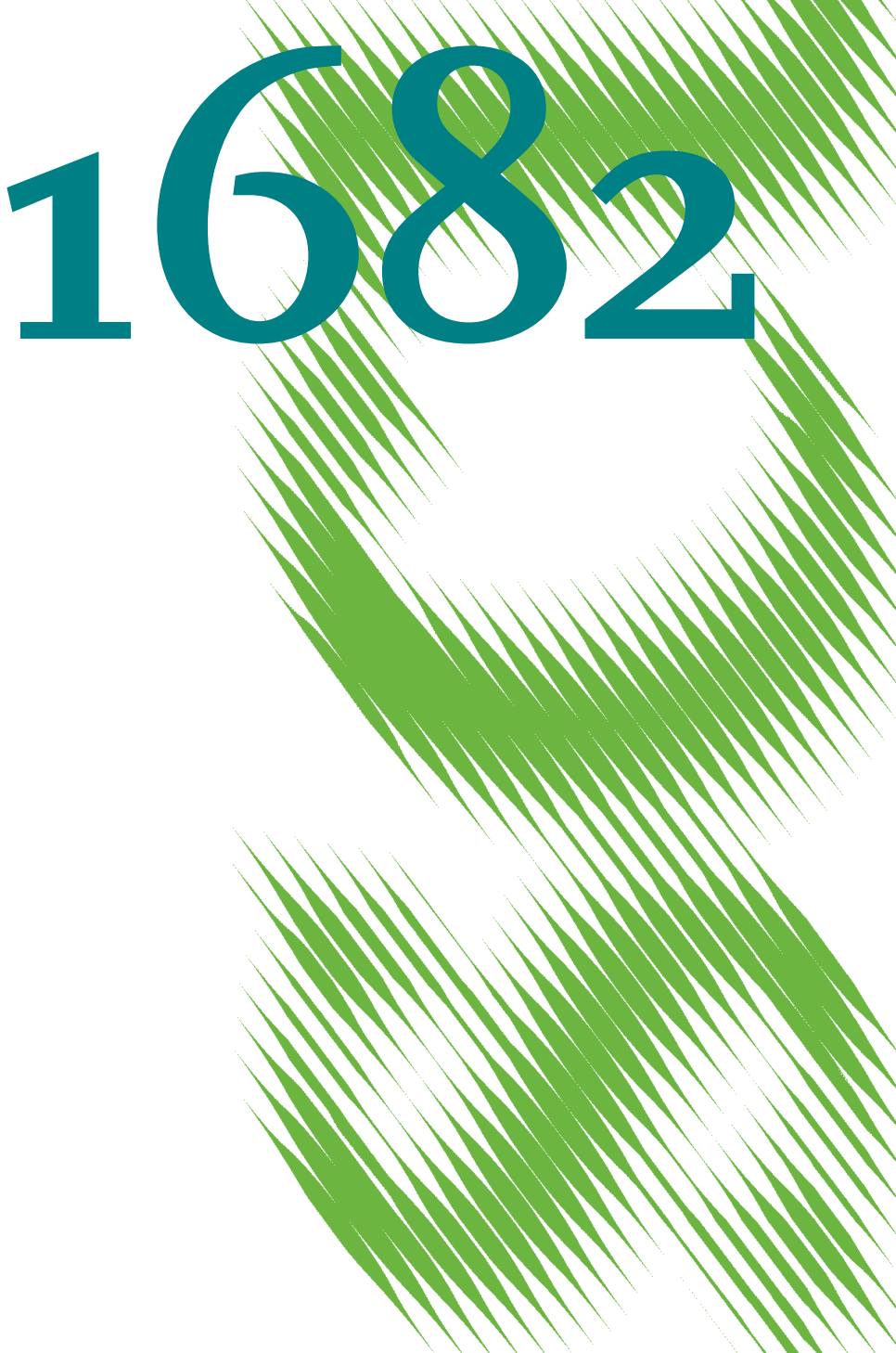

Does Financial Literacy Improve Financial Inclusion?

Cross Country Evidence 
Opinions expressed in this paper are those of the author(s) and do not necessarily reflect views of the institute.

IMPRESSUM

(C) DIW Berlin, 2017

DIW Berlin

German Institute for Economic Research

Mohrenstr. 58

10117 Berlin

Tel. +49 (30) $89789-0$

Fax +49 (30) $89789-200$

http://www.diw.de

ISSN electronic edition 1619-4535

Papers can be downloaded free of charge from the DIW Berlin website:

http://www.diw.de/discussionpapers

Discussion Papers of DIW Berlin are indexed in RePEc and SSRN:

http://ideas.repec.org/s/diw/diwwpp.html

http://www.ssrn.com/link/DIW-Berlin-German-Inst-Econ-Res.html 


\title{
Does Financial Literacy Improve Financial Inclusion? Cross Country Evidence
}

Antonia Grohmann, Theres Klühs and Lukas Menkhoff

\begin{abstract}
While financial inclusion is typically addressed by improving the financial infrastructure we show that financial literacy, representing the demand-side of financial markets, also has a beneficial effect. We study this effect at the cross-country level, which allows to consider institutional variation. Regarding "access to finance", financial infrastructure and financial literacy are mainly substitutes. However, regarding the "use of financial services", the effect of higher financial literacy strengthens the effect of more financial depth. The causal interpretation of these results is supported by IV-regressions. Moreover, the positive impact of financial literacy holds across income levels and several subgroups within countries.
\end{abstract}

JEL-Classification: $\quad$ O1 (economic development), G2 (financial institutions), D14 (personal finance)

Keywords: $\quad$ financial inclusion, financial literacy, financial institutions, financial development

July 28, 2017

We would like to thank for helpful comments of participants at several workshops and conferences, in particular, Christian Ambrosius, Thorsten Beck, Heidi Kaila, Stephan Klasen, Bruno Martorano, Matthias Rieger, Tobias Rossmann, Astrid Salzmann, Annekathrin Schoofs, Susan Steiner and Finn Tarp. Financial support by the German Research Foundation (DFG, grant RTG 1723 and grant CRC 190) is gratefully acknowledged.

Antonia Grohmann, German Institute for Economic Research (DIW Berlin), 10108 Berlin, Germany; agrohmann@diw.de.

Theres Klühs, Leibniz University Hannover, Department of Economics, Königsworther Platz 1, 30167 Hannover, Germany; kluehs@glad.uni-hannover.de.

Lukas Menkhoff, Humboldt-University Berlin; German Institute for Economic Research (DIW Berlin), 10108 Berlin, Germany; Leibniz University Hannover; lmenkhoff@diw.de. 


\section{Does Financial Literacy Improve Financial Inclusion? Cross Country Evidence}

\section{Introduction}

Financial inclusion, measured as access to and use of financial services, is an important goal of economic and, in particular, financial development. It is hence of high interest for policy makers to learn about drivers of financial inclusion and how these can be influenced by national policies. Research at the country level documents the state of access to financial services (Beck et al., 2007a). It shows, moreover, that better financial inclusion is related to country and institutional characteristics, such as more financial depth, physical proximity of financial institutions, low costs for financial accounts, or a strong legal system (Allen et al., 2016).

Thus, country studies on financial inclusion so far focus on the supply side of financial markets. However, shouldn't financial development consider more than the various aspects of financial infrastructure and legal background? Which role does the demand side play? It seems plausible that functioning financial markets do not only need good infrastructure but also informed customers, i.e. customers with a higher degree of financial literacy. Informed customers make better financial decisions for themselves and for their businesses, they support the effectiveness of the financial system by demanding more sophisticated financial services and they will demand financial inclusion. If, indeed, the degree of financial literacy makes a difference for financial inclusion, this seems to have a clear policy message.

Despite this almost natural line of argument, we provide the first empirical study at the country level examining the relation between financial literacy and financial inclusion. This has become possible due to a new dataset documenting the degree of financial literacy for 143 countries as described in Klapper et al. (2015). These novel data complement the World Bank's Findex data on the access to and use of financial services (Demirguc-Kunt and Klapper, 2012, 2013), and, of course, earlier data on financial and institutional country characteristics. These data allow us to contribute to the literature on financial inclusion in two major ways:

First, we establish the stylized fact that higher financial literacy is systematically related to better financial inclusion, also at a country level. We show this relationship for four measures of financial inclusion. These relations provide the first cross country evidence, extending a few studies with specific samples from single countries, thereby demonstrating a high external validity of this relationship. Of course, financial development is a comprehensive process so that the stylized fact of a relation between financial literacy and financial inclusion should be 
controlled for by potentially confounding country characteristics. Thus, we apply a large set of variables which have been introduced in the literature, including relevant general country characteristics, such as GDP per capita or education, or standard variables of financial infrastructure (see e.g. Allen et al., 2016). When adding these variables to the main relation of interest, we show that these variables reduce the coefficient on financial literacy but none of them eliminates the significant relation between financial literacy and financial inclusion. This supports the notion that financial infrastructure (supply) and financial literacy (demand) each have their own positive influence on financial inclusion (Beck and de la Torre, 2007b).

Beyond the fact of these two positive influences - of financial infrastructure and financial literacy - on financial inclusion, it seems interesting to examine their relation to each other: do supply and demand act rather as substitutes or complements? We find that the answer depends on the type of financial inclusion, which is our second major contribution. For access to financial services, in particular having a bank account, the marginal benefit of financial literacy decreases with higher financial depth, indicating that the two are mainly substitutes. If inclusion is about the use of financial services, however, and in this sense more advanced, financial literacy has a complementary effect on financial depth, so that the two even reinforce each other. Economically, it makes sense, for example, that active use of a bank account requires both, infrastructure and understanding about the infrastructure.

While a causal interpretation of these results with the effect going from financial literacy to financial inclusion seems to be logical, there is also more direct evidence for this. Such evidence with high internal validity is provided by micro-based studies, such as Cole et al. (2011), Doi et al. (2014), and Jamison et al. (2014). These studies hint at the positive role of financial literacy for financial inclusion. However, the samples and designs of these studies are specific so that it remains unclear to which extent results can be generalized. Thus we propose, in addition to our OLS results, an instrumental variable approach allowing for causal inference in our regressions.

We use the level of numeracy of primary school children as a conventional external instrument. As numeracy is a precondition for financial literacy, numeracy and financial literacy are indeed highly correlated. Moreover, we argue that numeracy only affects financial inclusion through financial literacy as this financial understanding is needed on top of mathematical ability for the decision to, for example, open an account. Reassuringly, it is indeed exactly the numeracy aspect of education that matters because reading ability, for example, does not pass the test for an instrument. Thus, using numeracy of children as an instrument for financial literacy of adults also supports the causal interpretation of financial 
literacy on financial inclusion. In addition to this conventional IV-approach we also apply the instrumental variable method developed by Lewbel (2012). This method does not rely on an external instrument, but instead uses heterogeneity in the error term of the first stage regression to generate instruments from within the existing model. Results also confirm those based on OLS regressions.

In robustness tests we show that main results hold for various sub-groups of income levels, i.e. samples of the poorest $40 \%$ and riches $60 \%$ of the population within a country, or regressions using financial literacy of men and women. Leading on from these results we argue that improving financial literacy would be beneficial for all countries at different stages of economic and financial development.

Literature. Our research is related to three strands of literature, i.e. on (i) financial inclusion at the country level, (ii) financial inclusion in micro studies and (iii) financial literacy. (i) Recent studies measure and explain financial access as a measure of outreach and inclusion. Beck et al. (2007a) present a dataset designed to measure financial outreach by looking at both elements of physical access to banking infrastructure and deposit and credit use per capita. They show that these measures of financial access are not determined by the same indicators as financial depth (see Levine et al., 2000). Neither religion nor (French) legal origin (LaPorta et al., 1998) are significantly correlated with these variables.

When researching the barriers to financial inclusion, a number of supply side factors have been studied. Factors such as high transaction costs, uncertainty, asymmetric information or a lack of physical access are often discussed as hindering efficient use of financial services (Armendariz de Aghion and Morduch, 2005; Karlan and Morduch, 2009). Hence these are supply-side reasons why formal banks and other financial institutions may not give credit or offer a savings account to clients. Klapper et al. (2016) elaborate on how lifting these barriers promotes financial inclusion. Thus, providing access and promoting the use of financial services, may directly reduce extreme poverty (Pande et al., 2012; Karlan et al., 2014; Jack and Suri, 2014).

(ii) The findings from cross-country studies are largely supported by a number of microstudies that assess the causes of financial inclusion by looking at the individual or household level via surveys or by running a randomized control trial. In a combined approach, Allen et al. (2016) show that women, the poor and those living in rural areas tend to be financially excluded. Christelis et a. (2013) show, using microdata, a strong link between portfolios held in different countries and the economic country environment. Further, a growing body of evidence suggests that providing access to bank accounts increases take-up rates of these 
accounts, household savings (Brune et al. 2016; Somville and Vandewalle, 2016), labor market activity (Bruhn and Love, 2014), income (Bruhn and Love, 2014), private and business expenditures (Ashraf et al., 2010; Dupas and Robinson, 2013) and decreases rural poverty (Burgess and Pande, 2005). Particularly, the effect of providing savings accounts seems to be robust as people shift away from storing money at home or holding it in the form of livestock or jewelry (Demirguc-Kunt et al., 2017). While Cole et al. (2011) also find that subsidized bank accounts have a positive effect on bank account take up, even very short financial literacy trainings can have a (smaller) desired effect, in particular for poor households. Beyond the provision of bank accounts, mobile money may support inclusion in other dimensions (e.g. Demirguc-Kunt et al., 2017). For example, Aker et al. (2016) find significant effects of digitized transfers on households' diet and food intake.

A few studies question strong results of having a bank account for downstream behaviors. Prina (2015) finds that providing zero cost bank accounts and prevalence of local banks increase take up of these bank accounts, but the author does not find an effect on asset accumulation. Dupas et al. (2016) present evidence from Chile, Malawi, and Uganda to show that providing only basic bank accounts does not result in significantly higher savings or other downstream outcomes.

(iii) Studies on financial literacy typically examine the relationship between financial literacy and good financial decision making, supporting financial inclusion, such as improving retirement savings (Lusardi and Mitchell, 2007; Skimmyhorn, 2016), savings accumulation (Jamison et al., 2014), stock holding (van Rooij et al., 2011), wealth (van Rooij et al., 2012), micro-entrepreneurs' financial practices (Drexler et al., 2014), investment decisions (Guiso and Viviano, 2015), and proper debt taking (Lusardi and Tufano, 2015). The advantage of these micro-based studies is their clear identification, ensuring that indeed an increase in financial literacy improves financial behavior (e.g., Miller et al., 2015; Kaiser and Menkhoff, 2017).

The only study we are aware of, which analyzes "economic literacy” in a cross-country setting is Jappelli (2010). While he shows several interesting relations, he does not study financial inclusion. Thus, summarizing the state of the literature, we add to it by looking at financial literacy and financial inclusion at a cross country basis.

Our study proceeds with five sections: Section 2 describes the empirical approach and data, Section 3 provides main results. Results for IV-regressions are shown in Section 4, while robustness checks are documented in Section 5 and conclusions in Section 6.

\section{Empirical approach and data}


This section provides information about the foundations of our empirical study. Section 2.1 introduces the methods used, Section 2.2 documents the data and their definitions and Section 2.3 presents descriptive statistics.

\subsection{Method}

This research aims to explain financial inclusion by a demand side variable, i.e. financial literacy, together with the supply of financial services. The most prominent measure of financial inclusion that is studied in the literature (as LHS-variable) is "having a bank account”. Among the RHS variables, the demand for financial services is provided by the degree of financial literacy, while supply of financial services is measured by variables such as the size of the financial sector, strength of legal rights and bank branches per square km. These supplyside variables have been previously analyzed in the literature on financial inclusion (Allen et al., 2016; Beck et al., 2007a).

We start our analysis with a simple OLS regression (with robust standard errors) in order to ease interpretation. We also use various IV-regressions and fractional response regressions and show the results later on. This OLS regression takes the following form:

$$
Y=\beta_{1} F L+\beta_{2} X+u
$$

Our main variable of interest is FL, the level of financial literacy in a country. $\boldsymbol{X}$ is a matrix of country and institutional specific control variables, details of which are discussed in the data section below.

\subsection{Data}

The data needed for our research result from the above sketched literature and contain six groups of variables: (i) financial literacy, financial inclusion measured as (ii) access to finance and (iii) use of financial services, and three groups of country control variables, i.e. (iv) general country characteristics, (v) financial infrastructure of a country and (vi) institutional country characteristics.

Financial literacy. The variable "financial literacy" is made up of four survey items. These survey items are collected by Gallup, together with the World Bank, and the Global Financial Literacy Center in a representative survey of more than 1,000 adults per country in 143 countries of the world in 2014. The items ask one question on three concepts and two questions on a fourth concept; these concepts are risk diversification, inflation, interest rate and interest compounding. The financial literacy score proposed in Klapper et al. (2015) and also used here is a dummy variable, giving a “ 1 ” if questions on at least three out of four financial 
literacy concepts are answered correctly by a person. The score per country is the proportion of 1,000 people asked that can answer questions on three out of four concepts correctly. These, and small variations of these questions have been commonly used in the literature to measure financial literacy (Xu and Zia, 2012; Lusardi and Mitchell, 2014).

Access to finance. We measure financial inclusion by studying four different outcome variables. First, we look at the proportion of the population that has a simple bank account at a formal financial institution, including mobile money accounts. Having a bank account is the basis for a large number of financial transactions and it makes holding as well as handling money easier and safer. This is a simple measure of access to financial services and has been used in a large number of studies (e.g., Karlan and Morduch, 2009; Brune et al., 2016). It measures the most basic form of financial inclusion. In addition, we consider one more measure of access to financial inclusion that is the proportion of adults in a country that has a debit card. Having a debit card is a more sophisticated form of financial inclusion than simply having a bank account. At the same time, having a debit card is clearly beneficial to those that hold it. It is both a more convenient and safer form of payment than cash. We expect these two measures of financial inclusion to be positively affected by financial literacy, as a good level of financial knowledge is needed to make sophisticated financial decisions.

Use of financial services. Furthermore, we also look at two variables that are designed to measure the use of financial services rather than just simple access to financial services. The first variable is the proportion of respondents that use a bank account to save. Saving at a formal institution is beneficial for bank customers for safety reasons. It can also play an important role in impulse control, as money is not being stored in an available form. Lastly, we also study the use of debit cards, as the benefits from debit cards can only really be reaped if they are used. Our fourth outcome variable is, therefore, the proportion of the population that used a debit card during the last year, conditional on having such a card.

General country characteristics. To get a meaningful result about the relationship between financial literacy and financial inclusion at the country level, we control for a set of variables that have been shown to be related to financial literacy in a large number of micro studies (Lusardi and Mitchell, 2014). Variable descriptions as well as respective summary statistics are shown in Table A1 in the Appendix. These variables can be grouped into three: country compositional characteristics that include the log of GDP per capita to control for income levels and the proportion of the population that is between 15 and 64, because people of working age have higher financial literacy than others (Klapper et al., 2015). Furthermore, 
we use a measure of educational attainment in the country in the form of the proportion of people that have completed secondary or tertiary education.

Financial infrastructure. The next group of variables describes financial characteristics of a country. Here we control for variables that measure the depth and breadth of the financial system. We include the private credit to GDP ratio as a measure of financial depth and so financial sector development. Moreover, we control for a variable that measures physical access to financial services: bank branch penetration per $1000 \mathrm{~km}^{2}$.

Institutional characteristics. In explaining financial inclusion further, we follow Allen et al. (2016) and use two variables that can be considered to measure country institutional characteristics that are robustly significant in their study. These are the strength of legal rights index, which measures the legal protection of borrowers and lenders in the country. We also include the ease of doing business index. This variable controls for how easy it is for a firm to operate in a country. In robustness checks, we also control for further variables which have been suggested in the literature. Correlations between the control variables are given in Table A2. In order to be consistent with the data about financial literacy, all other data used in this study also take the 2014 values. A list of countries included in this study is shown in Table A3 in the appendix.

\subsection{Descriptive statistics}

The descriptive statistics about the main explanatory variable, i.e. "financial literacy”, is provided in Panel A of Table 1. The variable is measured as a score over four items. The average score of the world is an unweighted average across all countries, which is 36.6. That means less than $37 \%$ of the survey participants provided three or four correct answers on four items capturing the dimensions of financial literacy. We also include an average that has been weighted by the population and that is even lower: $32 \%$ are considered financially literate.

$<$ Table 1 about here $>$

However, there is enormous heterogeneity. The score per country varies between $13 \%$ and $71 \%$. Of course, there are some patterns in this data to be expected from the literature (Lusardi and Mitchell, 2014). The financial literacy score is higher in richer countries as can be seen from the World Bank classification of countries according to four income groups. This applies to each of the questions (Figure 1). It is noticeable, that the average score is almost the same for lower middle and upper middle income countries on two of the questions. People in low income countries do better than in middle income countries in a few cases. Only the high income countries have a significantly higher average score for all questions. Moreover, income 
is related to financial literacy within countries. The richest $60 \%$ of adults have an 8 percentage points higher degree of financial literacy than the poorest $40 \%$ on average. Finally, on average, 6.5 percentage points more men than women are considered financially literate.

$<$ Figure 1 about here $>$

Regarding the indicators which measure financial inclusion, Panel B of Table 1 provides descriptive statistics. In our sample, $54.5 \%$ of all adults being captured by the survey have a simple bank account. This is slightly higher when looking at the average weighted by population size. Here $58.6 \%$ of the population has a bank account. The variation across countries is even larger than for financial literacy, as it ranges from $2 \%$ to $100 \%$, indicating that the broad population - in the extreme country cases - does either have hardly any account access or basically everyone has an account. As a second indicator for financial access we choose a more advanced product, i.e. owning a “debit card”. This applies to 39.5\% (or 37.8\% weighted by population) of the world population, with a range from $0 \%$ to $99 \%$.

Regarding the use of financial services, our first indicator is "saved at a financial institution last year" which applies to $22.6 \%$ of the covered population and $25.3 \%$ when weighted. The second indicator is "debit card used in the last year" which $28.4 \%$ of respondents that hold a debit card agree to (22.0\% weighted by population).

Overall, we see that just over half of the world population has access to a formal financial account and even fewer hold a more sophisticated debit card. The shares of people that actively use a financial product is obviously lower again than the share of product owners.

\section{Main results}

This section first presents results for the direct effects of financial literacy on financial inclusion and, second, the interaction effects with financial institutions. Regarding direct effects, these are shown for access to formal financial services (Section 3.1) and the use of this access (Section 3.2). Regarding interaction effects, these are shown for financial depth (Section 3.3) and bank branch penetration (Section 3.4).

\subsection{Access to financial services}

We start our analysis by examining the most basic measure of financial inclusion - the proportion of the population that has a bank account. To explain account penetration, we begin by using only financial literacy as a RHS variable and find a highly significant positive relationship (see column 1 in Table 2).

$<$ Table 2 about here $>$ 
However, financial inclusion is expected to also depend on other characteristics of development, in particular on the state of financial infrastructure. Hence, we control for the three sets of variables described above: in specification 2 we consider country characteristics, and in specification 3 we also consider financial and institutional characteristics. In column 2, the results show a positive and significant relationship between financial literacy and the proportion of the population that has a bank account. In addition, and as expected, log GDP per capita has a positive and significant effect on bank account ownership. The education variables do not turn significant because their potential impact is crowded out by the correlated GDP variable; if we take out the GDP variable (in unreported regressions), then the education variables become significant with a positive coefficient in some of the regressions.

Coming to the full specification in column 3, we see that there is indeed the expected significant positive relationship between financial depth (private credit to GDP) and financial inclusion. Moreover, the indicator for bank branch penetration and the ease of doing business variable have significant coefficients with the expected sign. Due to the ranking nature of the latter variable, the regulatory business environment has a negative sign, i.e. this should be interpreted as a supportive effect of the ease of doing business on access to financial services. It seems plausible that the consideration of further variables, which are related to the development process and its financial aspects, reduces the coefficient of financial literacy. However, the fact that this coefficient remains highly significant is crucial. Other things equal, a one percentage point increase in the proportion of financial literate people in a country, increases the rate of account ownership among the population by 0.511 percentage points. These results indicate that both - demand and supply in financial services - contribute to improving financial inclusion.

Next, we take the analysis one step further, by not simply looking at the "banked" population, but also at having a more sophisticated financial product. In columns 4 to 6 we run the same regressions as before, but this time explaining the proportion of the population that has a debit card as the outcome variable. We find the same pattern. There is a large and significant relation between financial literacy and the proportion of the population that has a debit card. This indicates that a one percentage point increase in the share of people knowledgeable about financial literacy increases the share of the population having a debit card by 0.518 percentage points (column 6). GDP per capita is another important correlate, and according to column 6 - financial depth, bank branch penetration and ease of doing business are further significant variables in the regressions. 
These results for both indicators of access to finance provide clear evidence that the demand side, in the form of financial literacy, plays an important role when it comes to understanding access to finance. This role seems to be additional to the contribution from general economic development and improvements in financial infrastructure.

\subsection{Use of financial services}

In this section we extend the analysis and do not just study the effect of financial literacy on having a certain financial product, but analyze the effect of financial literacy on using that product. We here consider two different types of use of financial products. First, we study the proportion of the general population that has saved at a formal financial institution. Second, we study the proportion of a population that has used their debit card during the last year. Results are developed in the same steps as in Section 3.1 (see Table 2) and are shown in Table 3.

$<$ Table 3 about here $>$

Column 1 studies the link between the proportion of the population that is financially literate and the proportion that has saved in a formal financial institution; the coefficient is positive as expected and statistically highly significant. When we also consider general country characteristics in column 2, GDP per capita is positively correlated with the proportion that has saved at a formal financial institution. Considering further financial country characteristics in column 3 we find that financial depth and - plausibly - bank branch penetration have positive relations with financial inclusion. The negative coefficient on the share of the adult population seems difficult to interpret economically.

Moreover, we study the relationship between the financial literacy level and debit card use in the last year. As before, column 4 shows a significant relation between financial literacy and debit card use within the last year. Further regressions in columns 5 and 6 present the same pattern as in columns 2 and 3 before with one exception: bank branch penetration becomes insignificant but higher education turns significant which makes sense for the relatively more complex financial product.

\subsection{Financial literacy and different levels of financial depth}

We here study how financial depth and financial literacy interact to affect access to and use of financial services. The purpose is to learn about how policy designed to impacts the supply and the demand side of financial development impact financial inclusion. Therefore, we extend the above introduced analyses by including an interaction term between financial literacy and private credit to GDP (as measure of financial depth) in the regressions (Table 4); 
we also show the average marginal effect graphically in Figure 3. Both interacted variables are centered around their means for ease of interpretation.

$<$ Table 4 about here $>$

$<$ Figure 3 about here $>$

The results show that the average marginal effect of financial literacy on the proportion of the population that has a bank account is higher for countries that have lower private credit to GDP ratios (column 1). However, there is no significant difference across different levels of financial depth in the marginal effect of financial literacy on the proportion of the population that has a debit card (column 2). In contrast to these results, the average marginal effect of financial literacy on savings at a formal financial institution (column 3) and using a debit card during the preceding year (column 4) are higher in countries that have higher private capital to GDP ratios.

These results suggest that increasing financial literacy in a population would increase account ownership, and the effect is largest in countries with low levels of financial depth. On the other hand, the average marginal effects of increasing financial literacy on the use of financial services in the form of savings at a formal financial institution and use of debit cards are highest in countries that have high levels of financial depth. Thus, results from the interaction term suggest the following pattern: regarding the access to finance, financial infrastructure and financial literacy are both largely independent from each other or rather substitute each other. In countries with a lower ratio of private credit to GDP, high levels of financial literacy can make up for the lack of financial infrastructure. By contrast, regarding the use of financial services, financial literacy seems to be a very useful complement to increase use of an existing financial infrastructure. Thus, financial literacy education improves financial inclusion under “all” circumstances: at lower levels of financial depth (early stages of financial development) literacy works rather as substitute to financial depth, at higher levels literacy becomes a kind of necessary complementary factor.

While we find a similar pattern for the interactions between financial literacy and GDP per capita, whose detailed results are shown in Section 5.1, the degree of bank branch penetration does not seem to be too crucial for the impact of financial literacy on financial inclusion as discussed in the following Section 3.4.

\subsection{Financial literacy and different levels of bank branch penetration}

In a next step we look at the interaction between financial literacy and physical access to financial services by introducing an interaction term, analogous to the procedure in Section 3.3 
above. The results are shown in Table 5. Graphical presentations of the average marginal effects of financial literacy at different levels of bank branch penetration (again centered around their means) are presented in Figure 4.

$<$ Table 5 about here>

$<$ Figure 4 about here $>$

The patterns that we see in these regressions are different from the patterns that we find above. The interaction term between financial literacy and bank branch penetration is insignificant and close to zero for all our measures of financial inclusion. This shows that the average marginal effect of financial literacy is constant for all levels of bank branch penetration. However, departing from the mean there is a positive yet decreasing marginal effect of financial literacy on bank account ownership for lower bank branch penetration. Also, the effect of financial literacy on the percentage of people that saved during the last year is positive and increasing (Figure 4). This makes sense since financial literacy should be more effective where actual banking facilities require people to apply good financial knowledge.

Overall, the regressions described in this Section 3 show for a large country sample what findings based on microdata have indicated: people with higher financial literacy are more financially included (Cole et al., 2011; Doi et al., 2014; Drexler et al., 2014; Jamison et al., 2014). An advantage of the cross-country study is - beyond its external validity - that we are able to control for a number of institutional variables and study interactions with these, which is typically impossible in work based on microeconomic data. Thus, we see that an improvement in financial literacy by the general population has heterogeneous effects, depending on the kind of financial inclusion: regarding access to finance, the effect of financial literacy is stronger at low levels of financial inclusion (at least when looking at bank account ownership), but regarding the use of financial services, more financial literacy seems to strengthen the effect of financial infrastructure. 
Instrumental variable regressions

In order to test whether the relationship between financial literacy and financial inclusion is causal we employ an instrumental variable approach. We follow two approaches which both confirm our OLS-regression results.

Numeracy as an instrument. In this paper we first look at teaching of numeracy in primary school as instrument for financial literacy. A good instrument needs to be highly correlated with financial literacy, but must not have any direct effects on financial inclusion. The kind of numerical skills that provide the foundations of good financial literacy are quite basic and are learned early on in life. It is highly likely that if the population of a country has good foundations in numeracy that it will also have higher levels of financial literacy. Indeed, good numeracy (Sekita, 2011) and education dedicated to economics (van Rooij et al., 2012) have previously been used in microdata studies on financial literacy to instrument for financial literacy.

At the same time, we argue that the quality of numeracy education in primary school has no direct effect on financial inclusion. First, as only adults are included in our financial inclusion variables, numeracy of children has no direct effect on this outcome. Children in primary school are not yet legally allowed to make financial decisions and indeed the indicators that we use in our regression measure financial inclusion by only looking at the population above the age of 15 . We are hence looking at two different sets of people. It is very unlikely that the numeracy skills of primary school children will have a direct effect on financial inclusion that does not work through financial literacy. Second, basic numeracy skills alone such as those taught in primary schools have no direct effect on financial inclusions. Being able to do basic calculations does not enable someone to be able to know the value of a bank account directly. Therefore, we believe that good basic numeracy skills such as those taught in primary schools, only effect financial inclusion though financial literacy.

We here use the quality of mathematics education in primary school as it is measured by the EDSTAT data (see Angrist et al., 2013, for details of data generation). This dataset makes educational achievement test scores comparable for a larger number of countries. Studies that are designed to test international achievements such as the PISA or the TIMSS survey usually do not include many developing countries. Fortunately, Angrist et al. (2013) also include countries that are only part of regional educational comparisons survey such as the LLECE, which covers countries in Latin America. Similarly, the SACMEQ only covers countries in Africa. The authors anchor these international and regional surveys to the US in order to make them comparable. 
There is, however, still the problem in this data that numeracy scores in primary school are not available for all countries. In this case we impute numeracy scores in primary school using numeracy scores in secondary school. If this information was also not available, we record the data point as missing. The imputation is described in Table A4 in the appendix. Hence our sample size, covering 93 countries, is smaller for the instrumental variable regression than for the OLS regression. For this reason, we rerun all OLS regression only using the 93 countries for which we have a numeracy score. The coefficient remains significant. These results, together with results for IV regressions are shown in Tables A6 and A7 in the Appendix.

First stage regression results are shown in Table A5 in the Appendix. Stock-Yogo Fstatistics are at 9.67 proving that the instrument is not weak. This can also be inferred by looking at the F-statistic for the first stage, which is 15.24 and so far above the commonly used cut off of 10. Together these tests indicate that numeracy in primary school is a valid instrument for financial literacy in our study. As we are only using one instrument, overidentification cannot be tested.

We repeat all OLS regressions shown in Table 2, using an IV-approach with the quality of numeracy education in primary school as an instrument. Results are depicted in Table 6. Column (1) shows the relationship without any control variables. The positive and significant relationship between the level of financial literacy and the proportion that has access to a bank remains and even gets larger. As before, we add control variables in two steps and confirm our previous results: financial literacy has a strong and significant effect on having a bank account. The high significance levels of the IV regressions indicate to us that this relationship is causal. We also find this pattern when looking at the proportion of people that have debit card as an outcome variable.

\section{$<$ Table 6 about here>}

As before, we also examine financial literacy and the use of financial services by IV regression analysis. Results are presented in Table 7 . The patterns are the same as for access to financial services. The effect of financial literacy on the use of financial services remains significant and the coefficient gets even larger. Hence, we find that financial literacy also has a significant and causal relationship on the use of financial services.

$<$ Table 7 about here $>$

Placebo IV regressions. Some may argue that numeracy levels of primary school children are not a suitable instrument for financial literacy. The exclusion restriction could potentially be violated. One could image that certain types of government, for example, are 
particularly interested in reducing poverty and so increase education and financial inclusion at the same time. If this were the case, it should also be possible to use other measures of educational quality, such as performance on literacy, as an instrument for financial literacy. The first stage regression is shown in Table A8, whereas the second stage regression is shown in Table A9. We can see from the first stage regression that literacy levels do not work as an instrument for financial literacy, as the F-statistics for weak instrument test is only 0.77 and hence far below the rule of thumb value of 10 . At the second stage financial literacy no longer explains financial inclusion when instrumented with literacy levels in primary school. Hence we show that numeracy, but not performance on general literacy, works as an instrument for financial literacy. This indicates to us that the exclusion restriction is not violated in the IV regressions that use numeracy as an instrument.

Within-model generated instruments. In addition to running conventional IVregressions, we also apply the recent approach developed by Lewbel (2012) to examine causality. We here explain its basic intuition. Instead of relying on external instruments and needing the exclusion restriction to hold, this method uses instruments that are generated from within the model. For this to be possible, two conditions need to hold: First, the error term of the first stage of the potentially endogenous variable (financial literacy in our case) on (a subset of) the potentially exogenous regressors $\mathrm{Z}$, has to be heteroscedastic, i.e. the error term of the first stage regression is $\operatorname{Cov}\left(Z, \varepsilon^{2}\right) \neq 0$. The second condition that needs to hold for the Lewbel (2012) model is that the products of the idiosyncratic errors of the first and second stage are uncorrelated with the subset of variables $\mathrm{Z}$ used in the first stage regression, hence $\operatorname{Cov}(Z, \varepsilon, u)=0$. To check that the first condition holds we run the Breusch-Pagan test for heteroscedasticity on the first stage regression and homoscedasticity is rejected at $1 \%$. The second condition holds by assumption.

If these two conditions hold instruments are then generated using (Z- $\bar{Z}) \hat{\varepsilon}$. Where $\bar{Z}$ is the mean of $Z$ and $\widehat{\varepsilon}$ is the estimated residuals in the first stage. Hence there is the same number of instruments as exogenous variables are included in the first stage. The generated instruments can be used by themselves or in combination with traditional instruments that are taken from outside the model.

We do not run the regression with the same full set of control variables as in the other regressions instead focus on a subset. We here only include those variables that can be argued to be determined outside the model i.e. the proportion of the population that has completed secondary school, the proportion of the population that has completed tertiary education, the number of banks per $1000 \mathrm{~km}^{2}$, strength of legal rights and ease of doing business. 
Results of the Lewbel model examining the potential impact of financial literacy on access to finance are shown in Table 8, whereas the results regarding the use of financial services are shown in Table 9. Both tables present regression results using numeracy in primary school as an instrument, using the generated instruments only and applying a combination of external and generated instruments.

$<$ Table 8 about here $>$

$<$ Table 9 about here $>$

The results confirm our earlier finding that financial literacy has a positive and significant impact on all our measures of financial inclusion that we use in this paper. Furthermore, the positive and significant coefficient, no matter whether we use just the generated instrument or a combination of generated and traditional instrument, confirm that the relationship between financial literacy and financial inclusion is causal.

Another advantage of the Lewbel model is that we can test for overidentification, which is not possible in IV regressions with only one instrument. The Hansen-J-statistic shows that overidentification is not a problem in our regression. The tables also provide the F-statistic of the first stage regression, which is consistently above 10 and so confirms that the instruments are not weak.

\section{$5 \quad$ Robustness}

The robustness section addresses three issues: It shows that our main findings also hold for various sub-groups within countries (Section 5.1), that they are robust to various changes in variable definitions or considerations (Section 5.2), and that different estimation techniques confirm results (Section 5.3).

\subsection{The effect of financial literacy for various sub-groups}

It is possible that financial literacy works differently for various groups across and within countries. Thus, we perform three kinds of analyses to test whether the overall results are robust and can be applied for policy purposes in various kinds of circumstances.

Interactions with different income levels across countries. We expect that the relationship between financial literacy and access to financial services will be stronger for lower income countries. There are several reasons that make us form this hypothesis. First, on an individual level as well as in our descriptive statistics we can see that high income is correlated with high financial literacy. The marginal effect of financial literacy in poor countries may hence be larger. Kaiser and Menkhoff (2017), indeed, also find that financial 
literacy trainings are less effective when baseline levels of financial literacy are high. At the same time, as we are here looking at simple financial services, access and use of financial services is already fairly high in higher income countries, there is therefore less "room for improvement”. For these reasons we expect the marginal effect of financial literacy to be higher in low GDP per capita countries.

In order to test if a larger proportion of the population being financially literate has heterogeneous effects depending on the income level of the population, we introduce an interaction term between financial literacy and GDP per capita in the regressions described above. Table 10 shows results of OLS regressions that include the interaction term. The outcome variables are the same as above. Columns (1) and (2) show results for access to finance, whereas columns (3) to (4) show the results for use of financial services. The dependent variables in the table were centered and hence the interaction term shows the effect of an increase in financial literacy at the mean GDP per capita. To increase clarity and give the effect of a change in financial literacy at all levels of GDP per capita we include figures that show the average marginal effect of financial literacy at each level of GDP. These can be seen in Figure 5 - there is one picture for each outcome variable.

$<$ Table 10 about here $>$

$<$ Figure 5 about here $>$

Table 10 and Figure 5 demonstrate that increasing the level of financial literacy of the population would have the strongest effect on account ownership in countries that have lower levels of GDP per capita, as hypothesized above. Increasing financial literacy would have the largest marginal effect on account ownership at levels of GDP per capita below the mean. The interaction term between financial literacy and log GDP per capita is negative but not significant, indicating that the effect of financial literacy on debit card ownership is similar at different levels of GDP.

Interestingly, the interaction between financial literacy and our measures of use of financial services is positive rather than negative. Further, Figure 5 clearly shows that the average marginal effect of financial literacy is higher at higher levels of GDP. This pattern can also be seen when looking at the proportion of people that has used a debit card during the last year.

In this section we learn that increasing the level of financial literacy in the population has heterogeneous effects for countries with different levels of GDP per capita. Interestingly, the effect of increasing financial literacy on access to finance would have the largest effect in 
countries with low levels of GDP per capita. The effect of increased financial literacy on use of financial services, however, is larger at higher levels of GDP per capita.

Different income groups within countries. In the last part of our analysis we test whether the link between financial literacy and financial inclusion is stronger for certain groups of the population than for other ones. To do this, we use data that show the proportion of the poorest $40 \%$ and richest $60 \%$ of the country that can answer questions on three out of four financial literacy concepts correctly. As the outcome variable we use respective measures of financial inclusion, i.e. also of the poorest $40 \%$ and richest $60 \%$ of the population. We rerun the regressions above, but this time broken down by within country income groups. Results are presented in Table 11. They show that the coefficient on the level of financial literacy of the richest $60 \%$ is larger than the coefficient on the level of financial literacy of the poorest $40 \%$ of the population. This cautiously indicates that the link between financial literacy and financial inclusion is tentatively stronger for the richer part of the population. However, when we test the difference between the coefficients, there is no significant difference between the two regression coefficients.

<Table 11 about here>

Different genders. We perform the same exercise for the proportion of men and women who are financially literate and for the proportion of men and women who own and use different financial products. Results are shown in Table 12. Here we can see that the coefficient of the proportion of women who are financially literate is consistently and considerably larger than the coefficient on the proportion of men who are financially literate. Moreover, difference in coefficients between men and women is significant for owning a debit card and for saving at a formal financial institution at a $10 \%$ level, only.

$<$ Table 12 about here $>$

\subsection{Changes in variable definitions and further considerations}

We here test whether the main results change when (i) looking at the effect of financial literacy on inclusion with respect to borrowing or (ii) high frequency of account use, (iii) adding political risk, ATM penetration and cost of bank account as further control variables, (iv) omitting the share of people aged 15-64 and secondary education from the estimation, (v) using disaggregated financial literacy items as variables of interest, and (vi) modifying the definition of income.

Financial literacy and borrowing. In this study we deliberately focus on the relationship of financial literacy and financial inclusion on the asset side of the balance sheet. 
As it is harder to determine the desired level of financial inclusion on the borrowing side, we do not study this form of inclusion in the main text (Schicks, 2014). However, we look at the relationship between inclusion w.r.t to borrowing and financial literacy here, by running our regressions with the proportion of the population that borrowed from a formal financial institution, the proportion that borrowed from an informal financial institution and the proportion that has used a credit card within the last year. Results for OLS and IV regressions are presented in Table A10. The results confirm the link between financial literacy and financial inclusion, also on the borrowing side: There is no significant relationship between financial literacy and borrowing at a formal financial institution. We find, however, a negative and significant relationship between financial literacy and the proportion of people that borrowed from an informal financial institution, indicating that there is a link between financial literacy and financial inclusion on the borrowing side. Lastly, the link between financial literacy and the proportion that used a credit card in the last year is positive and significant. All the OLS results are confirmed by the IV regressions.

Financial literacy and high frequency of account use. Our measures of financial access and use do not take into account the intensity to which certain financial services are actually utilized. The variable "high frequency of account use" alleviates this constraint by indicating the share of people that took money out of a formal bank account three or more times in a typical month. OLS and IV regression results are presented in Table A11. Estimation results are positively related and significant at the one percent level. The effect of a one percentage point higher share of adults being financial literate translates into an about 0.59 percentage point higher share of people using their account intensively. Interestingly, the coefficient for tertiary education turns significant indicating that above and beyond financial literacy, adults with higher education use their accounts more frequently.

Considering other control variables. Although we already control for a number of variables in our main regression, we here expand the number of control variables and see if our results still hold. The results of the exercise are shown in Table A12 for account ownership as the outcome variable. First, we introduce a political risk index into the regressions. This considerably reduces the sample size. The relationship between financial literacy and account ownership remains significant. Next, we introduce ATMs per km2, as an additional measure of physical access to finance into the regressions; again the coefficient on the relationship between financial literacy and account ownership remains positive and significant.

Fees levied on holding and using financial products constitute barriers to accessing finance. In fact, data from the Micro Findex data base (Demirguc-Kunt and Klapper, 2012) 
show that $29 \%$ of respondents without a bank account state the high costs hindering them to acquire one. Thus, we consider the annual cost of checking accounts as additional control variable in our OLS regressions. As we did not get access to more recent World Bank data, as a second-best approach we use data presented in Beck et al. (2008) that are available for 68 countries and were collected in 2004. In order to enlarge the sample size, we impute the cost data for 43 other countries by estimating the annual fees of a checking account with the following explanatory variables: the share of population above 15 years and financial institutional variables such as private credit to GDP, bank return on assets, and bank return on equity.

Using this information as proxy for the cost of financial services and products, we re-run the OLS regressions. The results are shown in Table A12 column (3). Notably, there is no great difference in the point estimate or significance level of financial literacy compared to the regressions run without the cost data.

Column (4) shows results from regressions only with countries for which the original bank account cost data by Beck et al. (2008) are available. The sample size shrinks in these estimations and so the significant effect of financial literacy on the financial access variables is reduced to the $10 \%$ level. It is worth noting that fees paid for the checking account do not have a significant effect on financial inclusion in either specification. Further, running the regressions without the cost variable but with the decreased sample size still yields nonsignificant effects of financial literacy. Hence, we conclude that the missing effects of financial literacy are due to the specific small sample and are not related to the inclusion of a bank account cost covariate. We here only show the results for the regressions explaining account ownership, but performed this exercise with all outcome variables and found similar results. Financial literacy remains significant, also when controlling for additional variables.

These checks make us confident to say that the cost of financial products should not be neglected in such estimations, however, financial literacy, nevertheless, remains to have a distinct effect on financial inclusion. Controlling additionally for dummies that classify our sample according to the World Bank definition into low, lower middle, upper middle and high income countries sheds light on whether financial literacy still has a distinct effect on financial access and use despite varying income levels. OLS regression results are depicted in Table A13. The statistically significant coefficient estimates of financial literacy range between 0.35 and 0.52 and are thus of comparable yet smaller size as the coefficients of our preferred OLS estimation (Tables 2 and 3). Except for the savings specification, the coefficients of the country 
group dummies show negative signs implying that access and use of financial services is more pronounced in high income countries.

Disaggregating financial literacy. As already mentioned, the variable of interest, financial literacy, depicts the share of a country's population that is able to answer 3 out of 4 financial literacy topics correctly. Disaggregating this measure and inserting the actual shares of correctly answered risk diversification, inflation, interest and interest compounding questions as explanatory variables, and running the OLS regression lets us disentangle which field of knowledge is most important in supporting financial access and financial use. At the same time, these measures set a lower standard of financial literacy than the rather harsh cut off of being able to answer questions on at least three out of four concepts. Considering that multicollinearity could endanger the results, we calculated the variance inflation factor for each of the explanatory variables and find that it never exceeds 10 . Based on this rule of thumb, we rule out multicollinearity in our case.

We find that there is no clear pattern about knowledge on a single financial literacy concept affecting financial access or use more than others. Rather, knowledge about interest rates influences the share of people that have an account or a debit card positively, whereas knowledge on inflation or interest compounding does not change the share of people with financial access. The financial use variables are also affected differently by the disaggregated financial literacy measures: Knowledge on interest compounding has a highly significant effect on saving at a formal financial institution which hints to the conclusion that more sophisticated financial products may require more sophisticated financial knowledge. On the contrary, using a debit card is affected significantly and positively by financial literacy on risk. Regression results are available upon request.

Omitting control variables. Even though the variance inflation factors of all control variables lie far below the threshold of 10, we re-run our OLS estimations omitting two variables to rule out biases possibly caused by high correlation between the control variables: The share of population aged 15-64 and secondary education (Tables A14 and A15). The results remain similar to the full specification in terms of significance and size. Multicollinearity seems to be no problem for the analysis.

Adding proxies for culture. Culture may influence the degree to which people access and use financial services. For this reason, we add three different types of variables that proxy cultural institutions as control variables in our OLS regressions. We control for religion (i) religion. We use data from the World Religion Dataset (Maoz and Henderson, 2013) from the year 2010. The variables display percentage shares of the population that adhere to the 
respective faiths. Results from this analysis are found in Table A16. Overall, the coefficient of financial literacy on all financial inclusion measures remains positive and significant.

Second, we employ (ii) Hofstede’s cultural dimensions (Hofstede et al., 2010) as proxy for culture which includes power distance, the degree of individualism, masculinity, uncertainty avoidance, long-term orientation, and indulgence (cf. Table A17). These dimensions of culture are measured on a scale from 0-100 with 100 displaying the specific dimension exactly and zero portraying its counterpart. Due to a big drop in observations, standard errors go up while coefficients remain largely stable compared to earlier Table A16 so that there is no significant relationship between financial literacy and financial inclusion in these regressions. With regards to the cultural dimensions, a more masculine, i.e. more competitive, society tends to be negatively correlated with financial inclusion whereas a high degree of long-term orientation and individualism positively affects access and use of financial services.

Lastly, Table A18 shows results from regressions including dummy variables for (iii) Scandinavian, French, and German legal origins (LaPorta et al., 2008) as additional control variables. British legal origin serves as reference category. The level of financial literacy in a country continues to have a distinct significant and positive effect on all measures of financial inclusion. Furthermore, countries with Scandinavian and German legal origins have a higher positive effect on financial access and use as compared to countries with British legal origin. However, as is often found in the literature, countries with French legal origin do not perform as well compared to British legal origin countries.

Applying different income definitions. In our standard regression specification, we use log GDP per capita in PPP constant 2011 international US-dollars as the measure of income. As expected, repeating this exercise with other income definitions such as log GNI per capita (as it is used by the World Bank for the derivations of its country classifications) does not change the results significantly. Rather, the size of the effect of financial literacy on the respective access and use measures is higher in these OLS regressions. Results are available upon request.

\subsection{Different estimation techniques}

Fractional response regressions. All our dependent variables reflect proportions of aggregated binary outcome questions. Papke and Wooldridge (1996) propose functional forms for regressions with such fractional variables that take into account their specific discrete characteristics. Thus, in order to check for the validity of the OLS results, we run probit 
regressions considering the fractional response nature of the data. Table A19 presents the marginal effects regarding the financial access and use variables and shows that they are similar in magnitude to the OLS results discussed earlier. Countries with a higher level of financial literacy have higher access to and higher use of financial products. Furthermore, higher financial depth affects access to accounts, owning a debit card and saving at formal financial institutions positively and significantly.

Quantile regressions. We also employ quantile regression analysis since this estimation strategy is more robust to outliers and provides a richer characterization of data so that the effect of a control variable along the distribution of the dependent variable may be measured and not just its conditional mean. We run quantile regressions at the $25^{\text {th }}, 50^{\text {th }}$, and $75^{\text {th }}$ quantile for our four outcome variables. Results are presented in Table A20. The impact of financial literacy on account ownership is highest for those countries at the median level of account ownership, however, an equality of coefficients test cannot rule out that these differences are significantly different from zero. Interestingly, the specifications with dependent variables describing the use of finance, show that the effect of financial literacy is significant at all estimated quantiles of the distribution albeit higher for the $75^{\text {th }}$ percentile - again an equality of quantile estimates test cannot rule out that they are statistically different from each other. Thus, we conclude that the effect of financial literacy on our four outcome variables is positive and significant at all levels of financial inclusion.

Interaction analysis with instrumental variable. As a last robustness check, we reestimate all OLS regressions with interactions in an instrumental variable setting. As above, numeracy among primary school children is used as instrument for financial literacy. Results for our three interaction terms are presented in Tables A21 to A23 and Figures A1- A3. These interaction terms show a similar pattern to the OLS results above, with sign on the interaction term in the regression being mostly the same. However the results tend to be insignificant, most probably because of the larger confidence interval caused by the lower number of observations. 


\section{Conclusion}

There is a considerable literature showing that good financial literacy leads to good financial decision making. To the best of our knowledge this is the first study that examines the link between financial literacy and financial inclusion at the country level. This comes with the advantage that contrary to individual level studies we can control for a large number of country, institutional, and financial characteristics. Further, we are able to study the heterogeneous effects of financial literacy in relation to these financial institutions. Knowing whether financial literacy effects financial inclusion and how this effect differs for country specific variables is crucial for policy makers that aim for increasing financial inclusion. At the same time, studying financial literacy and financial inclusion on a cross country level gives more external validity to a study than is possible in papers using country specific data.

We start our analysis by looking at the relationship between the proportions of people in a country that can be considered financially literate and four measures of financial inclusion.

Specifically, we study two measures of access to finance, i.e. having a bank account and having a debit card and two measures of use of financial services, i.e. savings at formal financial institutions and having used a debit card within the last year. We find a positive and significant relationship between financial literacy and all our measures of financial inclusion. This result holds when controlling for a large number of country, financial and institutional characteristics. Moreover, we confirm the causal interpretation of all our results using both a conventional IV strategy and the more recent approach developed by Lewbel (2012). Hence, results support the notion that both, the demand for financial services in the form of financial literacy and the supply of financial services are important for financial inclusion.

We further study the heterogeneous effects of financial literacy for different institutional backgrounds. We find that the marginal effect of financial literacy on access to finance is larger at low levels of financial depth, but the marginal effect of financial literacy on the use of financial services is larger at high levels of financial depth. Thus, from a policy perspective, improving financial literacy is always useful for improving financial inclusion. The country data suggest that at early stages of financial development literacy may be seen to some extent as alternative to increasing financial depth (representing infrastructure); at later stages of financial development, however, financial literacy seems to be a necessary ingredient in order to make full use of available infrastructure. Obviously, more research investigating these newly uncovered relations would be beneficial. 


\section{References}

Aker, Jenny, Rachid Boumnijel, Amanda McClelland and Niall Tierney (2016), Payment Mechanisms and Antipoverty Programs: Evidence from a Mobile Money Cash Transfer Experiment in Niger, Economic Development and Cultural Change, 65(1), 1-37.

Allen, Franklin, Asli Demirguc-Kunt, Leora Klapper and Maria Soledad Martinez Peria (2016), The Foundations of Financial Inclusion: Understanding Ownership and Use of Formal Accounts, Journal of Financial Intermediation, 27, 1-30.

Angrist, Noam, Harry Anthony Patrinos and Martin Schlotter (2013), An Expansion of a Global Data Set on Educational Quality, World Bank Policy Research Paper No. 6536.

Armendariz de Aghion, Beatriz and Jonathan Morduch (2005), The Economics of Microfinance, Cambridge, MA: MIT Press.

Ashraf, Nava, Dean Karlan, and Wesley Yin (2010), Female Empowerment: Further Evidence from a Commitment Savings Product in the Philippines, World Development, 38(3), 333344.

Beck, Thorsten, Asli Demirguc-Kunt and Maria Soledad Martinez Peria (2007a), Reaching out: Access to and Use of Banking Services across Countries, Journal of Financial Economics, 85(1), 234-266.

Beck, Thorsten and Augusto de la Torre (2007b), The Basic Analytics of Access to Financial Services, Financial Markets, Institutions and Instruments, 16(2), 79-117.

Beck, Thorsten, Asli Demirguc-Kunt and Maria Soledad Martinez Peria (2008), Banking Services for Everyone? Barriers to Bank Access and Use around the World, World Bank Economic Review, 22(3), 397-430.

Bruhn, Miriam and Inessa Love (2014), The Real Impact of Improved Access to Finance: Evidence from Mexico, Journal of Finance, 69(3), 1347-1369.

Brune, Lasse, Xavier Giné, Jessica Goldberg, and Dean Yang (2016), Facilitating Savings for Agriculture: Field Experimental Evidence from Malawi, Economic Development and Cultural Change, 64(2), 187-220.

Burgess, Robin, and Rohini Pande (2005), Do Rural Banks Matter? Evidence from the Indian Social Banking Experiment, American Economic Review, 95(3), 780-95.

Christelis, Dimitris, Dimitris Georgarakos and Michael Haliassos (2013), Differences in Portfolios across Countries: Economic Environment versus Household Characteristics, The Review of Economics and Statistics, 95(1), 220-236.

Cole, Shawn, Thomas Sampson and Bilal Zia (2011), Price or Knowledge? What Drives Demand for Financial Services in Emerging Markets? Journal of Finance, 66(6), 19331967.

Demirguc-Kunt and Leora Klapper (2012), Measuring Financial Inclusion: The Global Findex Database, World Bank Policy Research Paper, No. 6025.

Demirguc-Kunt, Asli and Leora Klapper (2013), Measuring Financial Inclusion: Explaining Variation in Use of Financial Services across and within Countries, Brookings Papers on Economic Activity, Spring 2013, 279-340.

Demirguc-Kunt, Asli, Leora Klapper, and Dorothe Singer (2017), Financial Inclusion and Inclusive Growth - A Review of Recent Empirical Evidence, World Bank Policy Research Paper, No. 8040.

Doi, Yoko, David McKenzie, and Bilal Zia (2014), Who You Train Matters: Identifying Combined Effects of Financial Education on Migrant Households, Journal of Development Economics, 109, 39-55.

Drexler, Alejandro, Greg Fisher, and Antoinette Schoar (2014), Keeping It Simple: Financial Literacy and Rules of Thumb, American Economic Journal: Applied Economics, 6(2), 131. 
Dupas, Pascaline, and Jonathan Robinson (2013), Savings Constraints and Microenterprise Development: Evidence from a Field Experiment in Kenya, American Economic Journal: Applied Economics, 5(1), 163-192.

Dupas, Pascaline, Dean Karlan, Jonathan Robinson, and Diego Ubfal (2016), Banking the Unbanked? Evidence from Three Countries, NBER Working Paper 22463.

Guiso, Luigi, and Eliana Viviano (2015), How Much Can Financial Literacy Help? Review of Finance, 19, 1347-1382.

Hofstede, Geert, Gert Jan Hofstede, Michael Minkov (2010), Cultures and Organizations: Software of the Mind. Revised and Expanded $3^{\text {rd }}$ Edition, New York: McGraw-Hill USA.

Jack, William and Tavneet Suri (2014), Risk Sharing and Transactions Costs: Evidence from Kenya’s Mobile Money Revolution, American Economic Review, 104(1), 183-223.

Jamison, Julian C., Dean Karlan, and Jonathan Zinman (2014), Financial Education and Access to Savings Accounts: Complements or Substitutes? Evidence from Ugandan Youth Clubs, NBER Working Paper, No. 20135.

Jappelli, Tullio (2010), Economic Literacy: An International Comparison, Economic Journal, 120(548), F429-F451.

Kaiser, Tim and Lukas Menkhoff (2017), Does Financial Education Impact Financial Literacy and Financial Behavior and If so, When? World Bank Economic Review, forthcoming.

Karlan, Dean and Jonathan Morduch (2009), Access to Finance, in: Handbook of Development Economics, Eds. Dani Rodrik and Mark Rosenzweig, Elsevier, Amsterdam, 4703-4784.

Karlan, Dean, Aishwarya Lakshmi Ratan and Jonathan Zinman (2014), Savings by and for the Poor: A Research Review and Agenda. Review of Income and Wealth, 60(1), 36-78.

Klapper, Leora, Annamaria Lusardi and Peter van Oudheusden (2015), Financial Literacy around the World: Insights from the Standards and Poor's Ratings Service Global Financial Literacy Survey, https://www.finlit.mhfi.com.

Klapper, Leora, Mayada El-Zoghbi, and Jake Hess (2016), Achieving the Sustainable Development Goals - The Role of Financial Inclusion, CGAP Working Paper.

LaPorta, Rafael, Florencio Lopez-de-Silanes, Andrei Shleifer and Robert W. Vishny (1998), Law and Finance, Journal of Political Economy, 106 (6), 1113-1155.

LaPorta, Rafael, Florencio Lopez-de-Silanes, and Andrei Shleifer (2008), The Economic Consequences of Legal Origins, Journal of Economic Literature 46(2), 285-332.

Lewbel, Arthur (2012), Using Heteroscedasticity to Identify and Estimate Mismeasured and Endogenous Regressor Models, Journal of Business and Economic Statistics, 30, 67-80.

Levine, Ross, Norman Loayza and Thorsten Beck (2000), Financial Intermediation and Growth: Causality and Causes, Journal Monetary Economics, 46(1), 31-77.

Lusardi, Annamaria and Olivia S. Mitchell (2007), Baby Boomer Retirement Security: The Roles of Planning, Financial Literacy, and Housing Wealth, Journal of Monetary Economics, 54(1), 205-224.

Lusardi, Annamaria and Olivia S. Mitchell (2014), The Economic Importance of Financial Literacy: Theory and Evidence, Journal of Economic Literature, 52(1), 5-44.

Lusardi, Annamaria and Peter Tufano (2015), Debt Literacy, Financial Experiences, and Overindebtedness, Journal of Pension Economics and Finance, 14(04), 332-368.

Maoz, Zeev, and Errol A. Henderson (2013), The World Religion Dataset, 1945-2010: Logic, Estimates, and Trends, International Interactions, 39(3).

Miller, Margaret, Julia Reichelstein, Christian Salas and Bilal Zia (2015), Can You Help Someone Become Financially Capable? A Meta-Analysis of the Literature, World Bank Research Observer, 30(2), 220-246.

Pande, Rohini, Shawn Cole, Anitha Sivasankaran, Gautam G. Bastian and Katherine Durlacher (2012), Does Poor People's Access to Formal Banking Services Raise Their Income?, EPPI-Centre, Social Science Research Unit, Institute of Education, University of London. 
Papke, Leslie E. and Jeffrey M. Wooldridge (1996), Econometric Methods for Fractional Response Variables with an Application to 401(k) Plan Participation Rates, Journal of Applied Econometrics, 11(6), 619-632.

Prina, Silvia (2015), Banking the Poor via Savings Accounts: Evidence from a Field Experiment, Journal of Development Economics, 115, 16-31.

Schicks, Jessica (2014), Over-Indebtedness in Microfinance - An Empirical Analysis of Related Factors on the Borrower Level, World Development, 54, 301-324.

Sekita, Shuizka (2011), Financial Literacy and Retirement Planning in Japan, Journal of Pension Economics and Finance, 10(04), 637-656.

Skimmyhorn, William (2016), Assessing Financial Education: Evidence from Bootcamp, American Economic Journal: Economic Policy, 8(2), 322-343.

Somville, Vincent and Lore Vandewalle (2016), Saving by Default: Evidence from a Field Experiment in Rural India, Graduate Institute of International and Development Studies Geneva Working Paper Series, No. HEIDWP02-2016.

Van Rooij, Maarten, Annamaria Lusardi and Rob Alessie (2011), Financial Literacy and Stock Market Participation, Journal of Financial Economics, 101(2), 449-472.

Van Rooij, Maarten C.J., Annamaria Lusardi and Rob J.M. Alessie (2012), Financial Literacy, Retirement Planning and Household Wealth, Economic Journal, 122(560), 449-478.

$\mathrm{Xu}$, Lisa and Bilal Zia (2012), Financial Literacy around the World, World Bank Policy Research Paper, No. 6107. 
Table 1

Panel A: Financial literacy summary statistics

\begin{tabular}{lcccccc}
\hline & & & & & Weighted & Weighted \\
& Mean & SD & Min & Max & mean & SD \\
\hline Financial literacy & 36.61 & 13.79 & 13 & 71 & 32.00 & 11.45 \\
Financial literacy, poorest 40\% & 31.72 & 13.15 & 7 & 67 & 27.00 & 10.51 \\
Financial literacy, richest 60\% & 39.96 & 14.66 & 14 & 76 & 35.40 & 12.36 \\
Financial literacy, men & 39.86 & 14.39 & 15 & 77 & 35.06 & 12.07 \\
Financial literacy, women & 33.54 & 13.61 & 8 & 70 & 29.00 & 11.36 \\
Risk diversification & 41.64 & 16.13 & 11 & 78 & 34.90 & 16.80 \\
Inflation & 52.46 & 12.59 & 17 & 78 & 49.95 & 10.71 \\
Interest & 49.74 & 11.77 & 16 & 79 & 48.10 & 8.46 \\
Interest compounding & 46.38 & 11.88 & 22 & 74 & 45.18 & 8.26 \\
\hline Observations & 143 & & & & &
\end{tabular}

Notes: Financial literacy is the proportion of the adult population that can answer at least three out of four questions correctly. Financial literacy, bottom $40 \%$ and $60 \%$, report the same for the bottom $40 \%$ and top $60 \%$ of the income distribution. Financial literacy of men and women is the proportion of men and women in a country that can answer at least 3 out 4 questions correctly. Risk diversification, inflation, interest and interest compounding depict the proportion of the population that answered each respective question correctly. Weighted means were weighted by the population.

\section{Panel B: Access and use of financial services summary statistics}

\begin{tabular}{lcccccc}
\hline & & & & & Weighted & Weighted \\
& Mean & SD & Min & Max & mean & SD \\
\hline Account ownership & 54.53 & 30.78 & 2 & 100 & 58.63 & 25.74 \\
Debit card ownership & 39.45 & 30.86 & 0 & 99 & 37.82 & 24.96 \\
Saved at formal fin. institution & 22.59 & 18.86 & 1 & 78 & 25.33 & 17.17 \\
Used debit card in the last year & 28.36 & 28.78 & 0 & 96 & 22.03 & 22.28 \\
\hline Observations & 143 & & & & &
\end{tabular}

Notes: Account ownership at formal financial institution denotes the proportion of the population that has an account at a formal financial institution, including mobile money accounts; debit card ownership depicts the proportion of the population that has a debit card; Saved at a formal financial institution is the proportion of the population that saved at a formal financial institution in the past 12 months; used debit card is the proportion of the population that used a debit card during the last year. Weighted means were weighted by the population. 
Table 2: Financial literacy and access to finance - OLS results

\begin{tabular}{|c|c|c|c|c|c|c|}
\hline & $\begin{array}{c}(1) \\
\text { Account } \\
\text { ownership } \\
\text { OLS }\end{array}$ & $\begin{array}{c}(2) \\
\text { Account } \\
\text { ownership } \\
\text { OLS }\end{array}$ & $\begin{array}{c}\text { (3) } \\
\text { Account } \\
\text { ownership } \\
\text { OLS }\end{array}$ & $\begin{array}{c}(4) \\
\text { Debit card } \\
\text { ownership } \\
\text { OLS }\end{array}$ & $\begin{array}{c}\text { (5) } \\
\text { Debit card } \\
\text { ownership } \\
\text { OLS }\end{array}$ & $\begin{array}{c}\text { (6) } \\
\text { Debit card } \\
\text { ownership } \\
\text { OLS }\end{array}$ \\
\hline Financial literacy & $\begin{array}{c}1.444 * * * \\
(0.101)\end{array}$ & $\begin{array}{c}0.712 * * * \\
(0.143)\end{array}$ & $\begin{array}{c}0.511^{* * * *} \\
(0.140)\end{array}$ & $\begin{array}{c}1.522^{* * *} \\
(0.125)\end{array}$ & $\begin{array}{c}0.687 * * * \\
(0.141)\end{array}$ & $\begin{array}{c}0.518 * * * \\
(0.154)\end{array}$ \\
\hline Log GDP p.c. (PPP) & & $\begin{array}{c}15.418 * * * \\
(2.414)\end{array}$ & $\begin{array}{l}13.223 * * * \\
(2.798)\end{array}$ & & $\begin{array}{c}15.876 * * * \\
(2.071)\end{array}$ & $\begin{array}{c}13.943 * * * \\
(2.550)\end{array}$ \\
\hline $\begin{array}{l}\text { Population share } \\
\text { between } 15 \text { and } 64\end{array}$ & & $\begin{array}{c}0.277 \\
(0.389)\end{array}$ & $\begin{array}{l}-0.239 \\
(0.342)\end{array}$ & & $\begin{array}{l}-0.037 \\
(0.334)\end{array}$ & $\begin{array}{l}-0.482 \\
(0.305)\end{array}$ \\
\hline $\begin{array}{l}\text { Secondary } \\
\text { education }\end{array}$ & & $\begin{array}{l}-0.007 \\
(0.108)\end{array}$ & $\begin{array}{c}0.018 \\
(0.106)\end{array}$ & & $\begin{array}{c}0.010 \\
(0.098)\end{array}$ & $\begin{array}{c}0.028 \\
(0.102)\end{array}$ \\
\hline $\begin{array}{l}\text { Tertiary } \\
\text { education }\end{array}$ & & $\begin{array}{c}0.050 \\
(0.145)\end{array}$ & $\begin{array}{l}-0.151 \\
(0.137)\end{array}$ & & $\begin{array}{l}0.230 * \\
(0.137)\end{array}$ & $\begin{array}{c}0.031 \\
(0.150)\end{array}$ \\
\hline $\begin{array}{l}\text { Private credit to } \\
\text { GDP }\end{array}$ & & & $\begin{array}{c}0.130 * * * \\
(0.031)\end{array}$ & & & $\begin{array}{c}0.093 * * \\
(0.044)\end{array}$ \\
\hline $\begin{array}{l}\text { Bank branches per } \\
1000 \mathrm{~km}^{2}\end{array}$ & & & $\begin{array}{c}0.058 * * * \\
(0.017)\end{array}$ & & & $\begin{array}{c}0.034 * * \\
(0.017)\end{array}$ \\
\hline $\begin{array}{l}\text { Strength of legal } \\
\text { rights index }\end{array}$ & & & $\begin{array}{c}0.309 \\
(0.542)\end{array}$ & & & $\begin{array}{l}-0.002 \\
(0.509)\end{array}$ \\
\hline $\begin{array}{l}\text { Ease of doing } \\
\text { business index }\end{array}$ & & & $\begin{array}{c}-0.102 * * \\
(0.049)\end{array}$ & & & $\begin{array}{l}-0.105^{*} \\
(0.053)\end{array}$ \\
\hline Constant & $\begin{array}{c}1.38 \\
(4.318)\end{array}$ & $\begin{array}{c}-132.72 * * * \\
(16.349)\end{array}$ & $\begin{array}{c}-71.89 * * * \\
(25.653)\end{array}$ & $\begin{array}{c}-16.77 * * * \\
(4.572)\end{array}$ & $\begin{array}{c}-134.95 * * * \\
(13.957)\end{array}$ & $\begin{array}{c}-77.52 * * * \\
(24.802)\end{array}$ \\
\hline $\mathrm{R}^{2}$ & 0.424 & 0.741 & 0.803 & 0.469 & 0.795 & 0.816 \\
\hline Observations & 140 & 136 & 119 & 140 & 136 & 119 \\
\hline
\end{tabular}


Table 3: Financial literacy and use of financial services - OLS results

\begin{tabular}{|c|c|c|c|c|c|c|}
\hline & $\begin{array}{l}(1) \\
\text { Saved at } \\
\text { formal fin. } \\
\text { institution } \\
\text { OLS }\end{array}$ & $\begin{array}{c}\text { (2) } \\
\text { Saved at } \\
\text { formal fin. } \\
\text { institution } \\
\text { OLS }\end{array}$ & $\begin{array}{c}\text { (3) } \\
\text { Saved at } \\
\text { formal fin. } \\
\text { institution } \\
\text { OLS }\end{array}$ & $\begin{array}{l}\text { (4) } \\
\text { Used debit } \\
\text { card in the } \\
\text { last year } \\
\text { OLS }\end{array}$ & $\begin{array}{c}\text { (5) } \\
\text { Used debit } \\
\text { card in the } \\
\text { last year } \\
\text { OLS }\end{array}$ & $\begin{array}{c}\text { (6) } \\
\text { Used debit } \\
\text { card in the } \\
\text { last year } \\
\text { OLS }\end{array}$ \\
\hline Financial literacy & $\begin{array}{l}1.022 * * * \\
(0.072)\end{array}$ & $\begin{array}{c}0.664 * * * \\
(0.089)\end{array}$ & $\begin{array}{c}0.529 * * * \\
(0.086)\end{array}$ & $\begin{array}{c}1.526^{* * *} \\
(0.127)\end{array}$ & $\begin{array}{c}0.809 * * * \\
(0.140)\end{array}$ & $\begin{array}{c}0.687 * * * \\
(0.155)\end{array}$ \\
\hline Log GDP p.c. (PPP) & & $\begin{array}{c}7.896 * * * \\
(1.547)\end{array}$ & $\begin{array}{c}6.238 * * * \\
(1.518)\end{array}$ & & $\begin{array}{c}12.052^{* * *} \\
(1.991)\end{array}$ & $\begin{array}{c}12.207 * * * \\
(2.391)\end{array}$ \\
\hline $\begin{array}{l}\text { Population share } \\
\text { between } 15 \text { and } 64\end{array}$ & & $\begin{array}{l}-0.380 \\
(0.240)\end{array}$ & $\begin{array}{c}-0.616 * * * \\
(0.217)\end{array}$ & & $\begin{array}{l}-0.341 \\
(0.277)\end{array}$ & $\begin{array}{c}-0.719 * * \\
(0.301)\end{array}$ \\
\hline $\begin{array}{r}\text { Secondary } \\
\text { education }\end{array}$ & & $\begin{array}{l}-0.108 \\
(0.072)\end{array}$ & $\begin{array}{l}-0.053 \\
(0.068)\end{array}$ & & $\begin{array}{l}-0.004 \\
(0.087)\end{array}$ & $\begin{array}{l}-0.031 \\
(0.094)\end{array}$ \\
\hline $\begin{array}{l}\text { Tertiary } \\
\text { education }\end{array}$ & & $\begin{array}{c}0.124 \\
(0.108)\end{array}$ & $\begin{array}{c}0.026 \\
(0.107)\end{array}$ & & $\begin{array}{c}0.420^{* * *} \\
(0.128)\end{array}$ & $\begin{array}{l}0.241^{*} \\
(0.142)\end{array}$ \\
\hline $\begin{array}{l}\text { Private credit to } \\
\text { GDP }\end{array}$ & & & $\begin{array}{l}0.114^{* *} \\
(0.045)\end{array}$ & & & $\begin{array}{c}0.046 \\
(0.041)\end{array}$ \\
\hline $\begin{array}{l}\text { Bank branches per } \\
1000 \mathrm{~km}^{2}\end{array}$ & & & $\begin{array}{l}0.033^{*} \\
(0.018)\end{array}$ & & & $\begin{array}{c}0.029 \\
(0.018)\end{array}$ \\
\hline $\begin{array}{l}\text { Strength of legal } \\
\text { rights index }\end{array}$ & & & $\begin{array}{c}0.146 \\
(0.410)\end{array}$ & & & $\begin{array}{c}0.332 \\
(0.498)\end{array}$ \\
\hline $\begin{array}{l}\text { Ease of doing } \\
\text { business index }\end{array}$ & & & $\begin{array}{l}-0.030 \\
(0.040)\end{array}$ & & & $\begin{array}{l}-0.074 \\
(0.059)\end{array}$ \\
\hline Constant & $\begin{array}{c}-15.105^{* * * *} \\
(2.480)\end{array}$ & $\begin{array}{c}-47.236 * * * \\
(11.256)\end{array}$ & $\begin{array}{l}-18.961 \\
(19.067)\end{array}$ & $\begin{array}{c}-27.818^{* * *} \\
(4.326)\end{array}$ & $\begin{array}{c}-98.05 * * * \\
(11.986)\end{array}$ & $\begin{array}{c}-65.957 * * \\
(29.774)\end{array}$ \\
\hline $\mathrm{R}^{2}$ & 0.565 & 0.683 & 0.737 & 0.539 & 0.779 & 0.779 \\
\hline Observations & 140 & 136 & 119 & 140 & 136 & 119 \\
\hline
\end{tabular}




\begin{tabular}{|c|c|c|c|c|}
\hline & $\begin{array}{c}\text { (1) } \\
\text { Account } \\
\text { ownership }\end{array}$ & $\begin{array}{c}\text { (2) } \\
\text { Debit card } \\
\text { ownership }\end{array}$ & $\begin{array}{c}\text { (3) } \\
\text { Saved at } \\
\text { formal fin. } \\
\text { institution }\end{array}$ & $\begin{array}{l}\text { (4) } \\
\text { Used debit } \\
\text { card in the } \\
\text { last year }\end{array}$ \\
\hline Financial literacy & $\begin{array}{c}0.550 * * * \\
(0.143)\end{array}$ & $\begin{array}{c}0.497 * * * \\
(0.157)\end{array}$ & $\begin{array}{c}0.492 * * * \\
(0.079)\end{array}$ & $\begin{array}{c}0.628 * * * \\
(0.152)\end{array}$ \\
\hline Private credit to GDP & $\begin{array}{c}0.146^{* * * *} \\
(0.033)\end{array}$ & $\begin{array}{l}0.085^{* *} \\
(0.042)\end{array}$ & $\begin{array}{l}0.098 * * \\
(0.042)\end{array}$ & $\begin{array}{c}0.022 \\
(0.036)\end{array}$ \\
\hline $\begin{array}{l}\text { Interaction financial literacy } \\
\text { and private credit to GDP }\end{array}$ & $\begin{array}{c}-0.004^{* *} \\
(0.002)\end{array}$ & $\begin{array}{c}0.002 \\
(0.002)\end{array}$ & $\begin{array}{l}0.004 * * \\
(0.002)\end{array}$ & $\begin{array}{c}0.006^{* * *} \\
(0.002)\end{array}$ \\
\hline Log GDP p.c. (PPP) & $\begin{array}{l}13.846^{* * * *} \\
(2.781)\end{array}$ & $\begin{array}{l}13.610 * * * \\
(2.599)\end{array}$ & $\begin{array}{c}5.643 * * * \\
(1.472)\end{array}$ & $\begin{array}{l}11.259 * * * \\
(2.333)\end{array}$ \\
\hline Population share between 15-64 & $\begin{array}{l}-0.414 \\
(0.360)\end{array}$ & $\begin{array}{l}-0.388 \\
(0.336)\end{array}$ & $\begin{array}{c}-0.448 * * \\
(0.214)\end{array}$ & $\begin{array}{l}-0.451 \\
(0.339)\end{array}$ \\
\hline Secondary education & $\begin{array}{c}0.026 \\
(0.103)\end{array}$ & $\begin{array}{c}0.024 \\
(0.104)\end{array}$ & $\begin{array}{l}-0.061 \\
(0.068)\end{array}$ & $\begin{array}{l}-0.042 \\
(0.093)\end{array}$ \\
\hline Tertiary education & $\begin{array}{l}-0.101 \\
(0.132)\end{array}$ & $\begin{array}{c}0.004 \\
(0.162)\end{array}$ & $\begin{array}{l}-0.021 \\
(0.114)\end{array}$ & $\begin{array}{c}0.166 \\
(0.153)\end{array}$ \\
\hline Bank branches per $1000 \mathrm{~km}^{2}$ & $\begin{array}{c}0.055^{* * *} \\
(0.017)\end{array}$ & $\begin{array}{l}0.036 * * \\
(0.016)\end{array}$ & $\begin{array}{l}0.036^{*} \\
(0.019)\end{array}$ & $\begin{array}{l}0.034^{* *} \\
(0.017)\end{array}$ \\
\hline Strength of legal rights index & $\begin{array}{c}0.473 \\
(0.561)\end{array}$ & $\begin{array}{l}-0.090 \\
(0.525)\end{array}$ & $\begin{array}{l}-0.011 \\
(0.397)\end{array}$ & $\begin{array}{c}0.082 \\
(0.471)\end{array}$ \\
\hline Ease of doing business index & $\begin{array}{c}-0.093 * \\
(0.051)\end{array}$ & $\begin{array}{c}-0.110 * * \\
(0.053)\end{array}$ & $\begin{array}{c}-0.039 \\
(0.037)\end{array}$ & $\begin{array}{l}-0.089 \\
(0.056)\end{array}$ \\
\hline Constant & $\begin{array}{c}-42.061 \\
(26.212)\end{array}$ & $\begin{array}{c}-55.322^{* *} \\
(24.754) \\
\end{array}$ & $\begin{array}{c}3.247 \\
(17.150) \\
\end{array}$ & $\begin{array}{c}-43.977 \\
(28.815)\end{array}$ \\
\hline $\mathrm{R}^{2}$ & 0.809 & 0.817 & 0.750 & 0.793 \\
\hline Observations & 119 & 119 & 119 & 119 \\
\hline
\end{tabular}

Notes: The table shows the effect of financial literacy, private credit to GDP and their interaction on different measures of financial inclusion, including access to and use of financial services. Robust standard errors in parentheses. The interacted variables were centered at their means which correspond to $57.31 \%$ of GDP for financial depth and $36.4 \%$ for financial literacy. ${ }^{* *}$, ** and * denote significance at the $1 \%, 5 \%$ and $10 \%$ levels, respectively. 
Table 5: Financial literacy, bank branch penetration and their interaction

\begin{tabular}{|c|c|c|c|c|}
\hline & $\begin{array}{c}\text { (1) } \\
\text { Account } \\
\text { ownership }\end{array}$ & $\begin{array}{c}(2) \\
\text { Debit card } \\
\text { ownership }\end{array}$ & $\begin{array}{c}\text { (3) } \\
\text { Saved at } \\
\text { formal fin. } \\
\text { institution }\end{array}$ & $\begin{array}{c}\text { (4) } \\
\text { Used debit } \\
\text { card in the } \\
\text { last year }\end{array}$ \\
\hline Financial literacy & $\begin{array}{c}0.506^{* * * *} \\
(0.141)\end{array}$ & $\begin{array}{c}0.518 * * * \\
(0.157)\end{array}$ & $\begin{array}{c}0.534^{* * *} \\
(0.086)\end{array}$ & $\begin{array}{c}0.686 * * * \\
(0.158)\end{array}$ \\
\hline Bank branches per 1000 km² & $\begin{array}{c}0.079 * * \\
(0.033)\end{array}$ & $\begin{array}{c}0.033 \\
(0.029)\end{array}$ & $\begin{array}{c}0.011 \\
(0.027)\end{array}$ & $\begin{array}{c}0.033 \\
(0.034)\end{array}$ \\
\hline $\begin{array}{l}\text { Interaction financial literacy } \\
\text { and bank branches per } 1000 \mathrm{~km}^{2}\end{array}$ & $\begin{array}{l}-0.003 \\
(0.003)\end{array}$ & $\begin{array}{c}0.000 \\
(0.004)\end{array}$ & $\begin{array}{c}0.003 \\
(0.003)\end{array}$ & $\begin{array}{l}-0.000 \\
(0.005)\end{array}$ \\
\hline Log GDP p.c. (PPP) & $\begin{array}{c}13.392 * * * \\
(2.834)\end{array}$ & $\begin{array}{l}13.936 * * * \\
(2.570)\end{array}$ & $\begin{array}{c}6.061^{* * *} \\
(1.479)\end{array}$ & $\begin{array}{l}12.236 * * * \\
(2.428)\end{array}$ \\
\hline Population share between 15-64 & $\begin{array}{l}-0.274 \\
(0.342)\end{array}$ & $\begin{array}{l}-0.480 \\
(0.303)\end{array}$ & $\begin{array}{c}-0.578 * * \\
(0.222)\end{array}$ & $\begin{array}{c}-0.725 * * \\
(0.302)\end{array}$ \\
\hline Secondary education & $\begin{array}{c}0.017 \\
(0.106)\end{array}$ & $\begin{array}{c}0.028 \\
(0.103)\end{array}$ & $\begin{array}{l}-0.052 \\
(0.067)\end{array}$ & $\begin{array}{l}-0.031 \\
(0.095)\end{array}$ \\
\hline Tertiary education & $\begin{array}{l}-0.129 \\
(0.140)\end{array}$ & $\begin{array}{c}0.030 \\
(0.147)\end{array}$ & $\begin{array}{c}0.004 \\
(0.114)\end{array}$ & $\begin{array}{l}0.245^{*} \\
(0.139)\end{array}$ \\
\hline Private credit to GDP & $\begin{array}{c}0.127 * * * \\
(0.032)\end{array}$ & $\begin{array}{c}0.094 * * \\
(0.043)\end{array}$ & $\begin{array}{c}0.117^{* * *} \\
(0.044)\end{array}$ & $\begin{array}{c}0.046 \\
(0.041)\end{array}$ \\
\hline Strength of legal rights index & $\begin{array}{c}0.279 \\
(0.548)\end{array}$ & $\begin{array}{l}-0.000 \\
(0.512)\end{array}$ & $\begin{array}{c}0.177 \\
(0.408)\end{array}$ & $\begin{array}{c}0.327 \\
(0.502)\end{array}$ \\
\hline Ease of doing business index & $\begin{array}{c}-0.098 * \\
(0.050)\end{array}$ & $\begin{array}{l}-0.105^{*} \\
(0.053)\end{array}$ & $\begin{array}{l}-0.034 \\
(0.040)\end{array}$ & $\begin{array}{l}-0.074 \\
(0.058)\end{array}$ \\
\hline Constant & $\begin{array}{c}-51.204^{* *} \\
(25.194) \\
\end{array}$ & $\begin{array}{c}-57.948 * * \\
(25.265) \\
\end{array}$ & $\begin{array}{c}0.236 \\
(18.639) \\
\end{array}$ & $\begin{array}{c}-40.174 \\
(29.623)\end{array}$ \\
\hline $\begin{array}{l}\mathrm{R}^{2} \\
\text { Observations }\end{array}$ & $\begin{array}{c}0.804 \\
119\end{array}$ & $\begin{array}{c}0.816 \\
119\end{array}$ & $\begin{array}{c}0.739 \\
119\end{array}$ & $\begin{array}{c}0.779 \\
119\end{array}$ \\
\hline
\end{tabular}

Notes: The table shows the effect of financial literacy, bank branch penetration and their interaction on different measures of financial inclusion, including access to and use of financial services. Robust standard errors in parentheses. The interacted variables were centered at their means which correspond to 22.44 for bank branches per $1000 \mathrm{~km}^{2}$ and $36.4 \%$ for financial literacy. ${ }^{* * *}, * *$ and $*$ denote significance at the $1 \%, 5 \%$ and $10 \%$ levels, respectively. 
Table 6: Financial literacy and access to financial services - IV results

\begin{tabular}{|c|c|c|c|c|c|c|}
\hline & $\begin{array}{c}\text { (1) } \\
\text { Account } \\
\text { ownership } \\
\text { IV }\end{array}$ & $\begin{array}{c}\text { (2) } \\
\text { Account } \\
\text { ownership } \\
\text { IV }\end{array}$ & $\begin{array}{c}\text { (3) } \\
\text { Account } \\
\text { ownership } \\
\text { IV }\end{array}$ & $\begin{array}{c}\text { (4) } \\
\text { Debit card } \\
\text { ownership } \\
\text { IV }\end{array}$ & $\begin{array}{c}\text { (5) } \\
\text { Debit card } \\
\text { ownership } \\
\text { IV }\end{array}$ & $\begin{array}{c}(6) \\
\text { Debit card } \\
\text { ownership } \\
\text { IV }\end{array}$ \\
\hline Financial literacy & $\begin{array}{l}2.520 * * * \\
(0.309)\end{array}$ & $\begin{array}{l}2.376 * * * \\
(0.679)\end{array}$ & $\begin{array}{l}1.885 * * * \\
(0.688)\end{array}$ & $\begin{array}{c}2.481 * * * \\
(0.281)\end{array}$ & $\begin{array}{c}1.910^{* * *} \\
(0.480)\end{array}$ & $\begin{array}{c}1.636 * * * \\
(0.522)\end{array}$ \\
\hline Log GDP p.c. (PPP) & & $\begin{array}{c}3.171 \\
(8.302)\end{array}$ & $\begin{array}{c}2.686 \\
(8.298)\end{array}$ & & $\begin{array}{l}7.818 \\
(5.628)\end{array}$ & $\begin{array}{c}6.230 \\
(5.903)\end{array}$ \\
\hline $\begin{array}{l}\text { Population share } \\
\text { between } 15 \text { and } 64\end{array}$ & & $\begin{array}{l}1.904^{*} \\
(0.995)\end{array}$ & $\begin{array}{c}1.063 \\
(0.926)\end{array}$ & & $\begin{array}{l}1.161 \\
(0.709)\end{array}$ & $\begin{array}{c}0.621 \\
(0.719)\end{array}$ \\
\hline $\begin{array}{r}\text { Secondary } \\
\text { education }\end{array}$ & & $\begin{array}{l}-0.204 \\
(0.198)\end{array}$ & $\begin{array}{r}-0.089 \\
(0.179)\end{array}$ & & $\begin{array}{l}-0.098 \\
(0.171)\end{array}$ & $\begin{array}{l}-0.011 \\
(0.171)\end{array}$ \\
\hline $\begin{array}{l}\text { Tertiary } \\
\text { education }\end{array}$ & & $\begin{array}{c}-0.552 * * \\
(0.267)\end{array}$ & $\begin{array}{l}-0.364^{*} \\
(0.188)\end{array}$ & & $\begin{array}{l}-0.295 \\
(0.213)\end{array}$ & $\begin{array}{l}-0.233 \\
(0.185)\end{array}$ \\
\hline $\begin{array}{l}\text { Private credit to } \\
\text { GDP }\end{array}$ & & & $\begin{array}{l}0.119 * * \\
(0.049)\end{array}$ & & & $\begin{array}{l}0.076^{*} \\
(0.044)\end{array}$ \\
\hline $\begin{array}{l}\text { Bank branches per } \\
1000 \mathrm{~km}^{2}\end{array}$ & & & $\begin{array}{c}0.064 \\
(0.061)\end{array}$ & & & $\begin{array}{c}0.030 \\
(0.057)\end{array}$ \\
\hline $\begin{array}{l}\text { Strength of legal } \\
\text { rights index }\end{array}$ & & & $\begin{array}{l}-1.078 \\
(1.028)\end{array}$ & & & $\begin{array}{l}-1.162 \\
(0.818)\end{array}$ \\
\hline $\begin{array}{l}\text { Ease of doing } \\
\text { business index }\end{array}$ & & & $\begin{array}{l}-0.048 \\
(0.096)\end{array}$ & & & $\begin{array}{l}-0.064 \\
(0.089)\end{array}$ \\
\hline Constant & $\begin{array}{c}-37.54 * * * \\
(12.010)\end{array}$ & $\begin{array}{c}-164.84^{* * *} \\
(27.857)\end{array}$ & $\begin{array}{l}-96.14 * * \\
(42.738)\end{array}$ & $\begin{array}{c}-50.55 * * * \\
(11.281)\end{array}$ & $\begin{array}{c}-167.78^{* * *} \\
(21.879)\end{array}$ & $\begin{array}{c}-107.91^{* * * *} \\
(39.002)\end{array}$ \\
\hline$\overline{\mathrm{R}^{2}}$ & 0.186 & 0.453 & 0.640 & 0.301 & 0.648 & 0.702 \\
\hline Observations & 99 & 98 & 93 & 99 & 98 & 93 \\
\hline
\end{tabular}


Table 7: Financial literacy and use of financial services - IV results

\begin{tabular}{|c|c|c|c|c|c|c|}
\hline & $\begin{array}{l}\text { (1) } \\
\text { Saved at } \\
\text { formal fin. } \\
\text { institution } \\
\text { IV }\end{array}$ & $\begin{array}{c}\text { (2) } \\
\text { Saved at } \\
\text { formal fin. } \\
\text { institution } \\
\text { IV }\end{array}$ & $\begin{array}{c}\text { (3) } \\
\text { Saved at } \\
\text { formal fin. } \\
\text { institution } \\
\text { IV }\end{array}$ & $\begin{array}{c}\text { (4) } \\
\text { Used debit } \\
\text { card in the } \\
\text { last year } \\
\text { IV }\end{array}$ & $\begin{array}{c}\text { (5) } \\
\text { Used debit } \\
\text { card in the } \\
\text { last year } \\
\text { IV }\end{array}$ & $\begin{array}{c}\text { (6) } \\
\text { Used debit } \\
\text { card in the } \\
\text { last year } \\
\text { IV }\end{array}$ \\
\hline Financial literacy & $\begin{array}{c}1.510 * * * \\
(0.186)\end{array}$ & $\begin{array}{c}1.439 * * * \\
(0.444)\end{array}$ & $\begin{array}{c}1.117^{* * * *} \\
(0.410)\end{array}$ & $\begin{array}{c}2.367 * * * \\
(0.246)\end{array}$ & $\begin{array}{c}1.759 * * * \\
(0.389)\end{array}$ & $\begin{array}{c}1.630 * * * \\
(0.505)\end{array}$ \\
\hline Log GDP p.c. (PPP) & & $\begin{array}{c}2.656 \\
(4.885)\end{array}$ & $\begin{array}{c}1.388 \\
(4.773)\end{array}$ & & $\begin{array}{c}6.305 \\
(4.651)\end{array}$ & $\begin{array}{l}5.520 \\
(5.096)\end{array}$ \\
\hline $\begin{array}{l}\text { Population share } \\
\text { between } 15 \text { and } 64\end{array}$ & & $\begin{array}{c}0.374 \\
(0.675)\end{array}$ & $\begin{array}{l}-0.114 \\
(0.601)\end{array}$ & & $\begin{array}{c}0.600 \\
(0.606)\end{array}$ & $\begin{array}{c}0.326 \\
(0.739)\end{array}$ \\
\hline $\begin{array}{r}\text { Secondary } \\
\text { education }\end{array}$ & & $\begin{array}{l}-0.168 \\
(0.140)\end{array}$ & $\begin{array}{c}-0.042 \\
(0.127)\end{array}$ & & $\begin{array}{l}-0.060 \\
(0.144)\end{array}$ & $\begin{array}{l}-0.019 \\
(0.151)\end{array}$ \\
\hline $\begin{array}{l}\text { Tertiary } \\
\text { education }\end{array}$ & & $\begin{array}{l}-0.137 \\
(0.194)\end{array}$ & $\begin{array}{c}-0.059 \\
(0.147)\end{array}$ & & $\begin{array}{c}0.013 \\
(0.191)\end{array}$ & $\begin{array}{c}0.030 \\
(0.182)\end{array}$ \\
\hline $\begin{array}{l}\text { Private credit to } \\
\text { GDP }\end{array}$ & & & $\begin{array}{l}0.101^{* *} \\
(0.041)\end{array}$ & & & $\begin{array}{c}0.030 \\
(0.042)\end{array}$ \\
\hline $\begin{array}{l}\text { Bank branches per } \\
1000 \mathrm{~km}^{2}\end{array}$ & & & $\begin{array}{l}0.075^{*} \\
(0.040)\end{array}$ & & & $\begin{array}{c}0.016 \\
(0.058)\end{array}$ \\
\hline $\begin{array}{l}\text { Strength of legal } \\
\text { rights index }\end{array}$ & & & $\begin{array}{c}-0.486 \\
(0.735)\end{array}$ & & & $\begin{array}{l}-0.611 \\
(0.799)\end{array}$ \\
\hline $\begin{array}{l}\text { Ease of doing } \\
\text { business index }\end{array}$ & & & $\begin{array}{c}-0.011 \\
(0.059)\end{array}$ & & & $\begin{array}{l}-0.038 \\
(0.091)\end{array}$ \\
\hline Constant & $\begin{array}{c}-33.12 * * * \\
(7.122)\end{array}$ & $\begin{array}{c}-68.54 * * * \\
(20.657)\end{array}$ & $\begin{array}{c}-25.66 \\
(27.199)\end{array}$ & $\begin{array}{c}-58.33 * * * \\
(9.854)\end{array}$ & $\begin{array}{c}-130.99 * * * \\
(19.254)\end{array}$ & $\begin{array}{l}-99.82 * * \\
(43.958)\end{array}$ \\
\hline$\overline{\mathrm{R}^{2}}$ & 0.506 & 0.570 & 0.675 & 0.456 & 0.706 & 0.698 \\
\hline Observations & 99 & 98 & 93 & 99 & 98 & 93 \\
\hline
\end{tabular}

Notes: The table reports IV regression results with robust standard errors in parentheses. Columns (1) to (3) show results with the proportion of the population that saved at a formal financial institution in the last year as the outcome variable. Column (4) - (6) show results with the proportion that used their debit card in the last year as an outcome variable. Numeracy in primary schools acts as an instrument in these regressions. ***, ** and * denote significance at the $1 \%, 5 \%$ and $10 \%$ levels, respectively. 
Table 8: Financial literacy and access to finance: IV results using Lewbel (2012)

\begin{tabular}{|c|c|c|c|c|c|c|}
\hline & (1) & (2) & (3) & (4) & (5) & (6) \\
\hline & \multirow{2}{*}{\multicolumn{3}{|c|}{$\begin{array}{l}\text { Account ownership } \\
\text { Lewbel }\end{array}$}} & \multirow{2}{*}{\multicolumn{3}{|c|}{$\begin{array}{l}\text { Debit card ownership } \\
\text { Lewbel }\end{array}$}} \\
\hline & & & & & & \\
\hline & $\begin{array}{l}\text { Standard } \\
\text { IV }\end{array}$ & $\begin{array}{c}\text { generated } \\
\text { instruments }\end{array}$ & $\begin{array}{c}\text { Combined } \\
\text { model }\end{array}$ & $\begin{array}{l}\text { Standard } \\
\text { IV }\end{array}$ & $\begin{array}{c}\text { generated } \\
\text { instruments }\end{array}$ & $\begin{array}{l}\text { Combined } \\
\text { model }\end{array}$ \\
\hline \multirow{2}{*}{ Financial literacy } & $2.201 * * *$ & $1.249 * * *$ & $1.428 * * *$ & $1.831 * * *$ & $1.750 * * *$ & $1.71 * * *$ \\
\hline & $(0.823)$ & $(0.307)$ & $(0.270)$ & $(0.622)$ & $(0.302)$ & $(0.247)$ \\
\hline \multirow{2}{*}{$\begin{array}{r}\text { Secondary } \\
\text { education }\end{array}$} & 0.011 & 0.0731 & 0.0615 & 0.115 & 0.120 & 0.1223 \\
\hline & $(0.225)$ & $(0.161)$ & $(0.169)$ & $(0.191)$ & $(0.182)$ & $(0.179)$ \\
\hline \multirow{2}{*}{$\begin{array}{l}\text { Tertiary } \\
\text { education }\end{array}$} & -0.433 & -0.007 & -0.077 & -0.096 & -0.064 & -0.0512 \\
\hline & $(-0.379)$ & $(0.196)$ & $(0.2017)$ & $(0.302)$ & $(0.222)$ & $(0.199)$ \\
\hline \multirow{2}{*}{$\begin{array}{l}\text { Bank branches per } \\
1000 \mathrm{~km}^{2}\end{array}$} & $0.1407 * *$ & $0.138 * * *$ & $0.138 * * *$ & 0.0862 & $0.0859 *$ & $0.0858 *$ \\
\hline & $(0.064)$ & $(0.044)$ & $(0.047)$ & $(0.053)$ & $(0.0513)$ & 0.0508 \\
\hline \multirow{2}{*}{$\begin{array}{l}\text { Strength of legal } \\
\text { rights index }\end{array}$} & $-2.146 * *$ & $-1.647 * *$ & $-1.741^{* *}$ & $-2.244 * * *$ & $-2.20 * * *$ & $-2.18 * * *$ \\
\hline & $(0.915)$ & $(0.670)$ & $(0.677)$ & $(0.758)$ & $(0.6984)$ & $(0.677)$ \\
\hline \multirow{2}{*}{$\begin{array}{l}\text { Ease of doing } \\
\text { business index }\end{array}$} & -0.176 & $-0.238 * * *$ & $-0.226 * * *$ & $-0.189 * * *$ & $-0.194 * * *$ & $-0.197 * * *$ \\
\hline & $(0.11)$ & $(0.0740)$ & $(0.077)$ & $(0.094)$ & $(0.080)$ & $(0.081)$ \\
\hline \multirow[t]{2}{*}{ Constant } & 1.263 & 30.531 & 25.01 & -6.92 & -4.449 & -3.425 \\
\hline & (32.98) & $(20.712)$ & $(20.806)$ & $(28.7)$ & $(22.489)$ & $(22.26)$ \\
\hline Observations & 95 & 95 & 95 & 95 & 95 & 95 \\
\hline Hansen J-statistic & 0 & 8.8 & 8.18 & 0 & 4.29 & 4.53 \\
\hline \multicolumn{7}{|l|}{ Hansen J-statistic } \\
\hline p-value & 0 & 0.066 & 0.147 & 0 & 0.368 & 0.476 \\
\hline \multicolumn{7}{|l|}{ F-statistics of first } \\
\hline stage & 10.58 & 10.65 & 12.92 & 10.58 & 10.65 & 12.92 \\
\hline
\end{tabular}

Notes: The table reports the results of Lewbel model regression, of financial literacy on access to finance. Columns (1) and (4) show results for standard IV regressions. Columns (2) and (5) show results of regressions using generated instruments only, columns (3) and (6) show results regressions using a combination of generated and external instruments. 
Table 9: Financial literacy and use of financial services: IV results using Lewbel (2012)
(1)
(2)
(3)
(4)
(5)
(6)

Saved at formal fin. institution Used debit card in last year

\begin{tabular}{|c|c|c|c|c|c|c|}
\hline & $\begin{array}{l}\text { Standard } \\
\text { IV }\end{array}$ & $\begin{array}{c}\text { Lewbel } \\
\text { generated } \\
\text { instruments }\end{array}$ & $\begin{array}{c}\text { Combined } \\
\text { model }\end{array}$ & $\begin{array}{c}\text { Standard } \\
\text { IV }\end{array}$ & $\begin{array}{c}\text { Lewbel } \\
\text { generated } \\
\text { instruments }\end{array}$ & $\begin{array}{c}\text { Combined } \\
\text { model }\end{array}$ \\
\hline Financial literacy & $\begin{array}{l}1.329 * * * \\
(0.473)\end{array}$ & $\begin{array}{l}1.518 * * * \\
(0.255)\end{array}$ & $\begin{array}{c}1.488 * * * \\
(0.202)\end{array}$ & $\begin{array}{c}1.714^{* * *} \\
(0.528)\end{array}$ & $\begin{array}{c}2.095 * * * \\
(0.365)\end{array}$ & $\begin{array}{c}1.944 * * * \\
(.2785)\end{array}$ \\
\hline $\begin{array}{l}\text { Secondary } \\
\text { education }\end{array}$ & $\begin{array}{l}-0.0964 \\
(0.142)\end{array}$ & $\begin{array}{r}-0.109 \\
(0.140)\end{array}$ & $\begin{array}{l}-0.1067 \\
(0.1406)\end{array}$ & $\begin{array}{c}0.089 \\
(0.150)\end{array}$ & $\begin{array}{l}0.0648 \\
(0.173)\end{array}$ & $\begin{array}{c}0.075 \\
(0.162)\end{array}$ \\
\hline $\begin{array}{l}\text { Tertiary } \\
\text { education }\end{array}$ & $\begin{array}{r}-0.0215 \\
(0.222)\end{array}$ & $\begin{array}{l}-0.095 \\
(0.167)\end{array}$ & $\begin{array}{l}-0.0836 \\
(0.1547)\end{array}$ & $\begin{array}{c}0.160 \\
(0.231)\end{array}$ & $\begin{array}{r}0.0117 \\
(0.228)\end{array}$ & $\begin{array}{l}0.0707 \\
(0.184)\end{array}$ \\
\hline $\begin{array}{l}\text { Bank branches per } \\
1000 \mathrm{~km}^{2}\end{array}$ & $\begin{array}{c}0.098 * * \\
(0.040)\end{array}$ & $\begin{array}{l}0.098 * * \\
(0.042)\end{array}$ & $\begin{array}{l}0.098 * * \\
(0.041)\end{array}$ & $\begin{array}{c}0.051 \\
(0.053)\end{array}$ & $\begin{array}{c}0.052 \\
(0.058)\end{array}$ & $\begin{array}{c}0.052 \\
(0.056)\end{array}$ \\
\hline $\begin{array}{l}\text { Strength of legal } \\
\text { rights index }\end{array}$ & $\begin{array}{l}-0.863 \\
(0.663)\end{array}$ & $\begin{array}{l}-0.962 \\
(0.527)\end{array}$ & $\begin{array}{l}-0.946 \\
(0.589)\end{array}$ & $\begin{array}{c}-1.390 * * \\
(0.692)\end{array}$ & $\begin{array}{c}-1.590 * * \\
(0.725)\end{array}$ & $\begin{array}{c}-1.511 * * \\
(0.674)\end{array}$ \\
\hline $\begin{array}{l}\text { Ease of doing } \\
\text { business index }\end{array}$ & $\begin{array}{l}-0.059 \\
(0.0621)\end{array}$ & $\begin{array}{l}-0.0465 \\
(0.063)\end{array}$ & $\begin{array}{l}-0.048 \\
(0.061)\end{array}$ & $\begin{array}{l}-0.124 \\
(0.085)\end{array}$ & $\begin{array}{l}-0.099 \\
(.0836)\end{array}$ & $\begin{array}{l}-0.109 \\
(0.082)\end{array}$ \\
\hline Constant & $\begin{array}{l}-14.012 \\
(18.632) \\
\end{array}$ & $\begin{array}{l}-19.799 \\
(18.543) \\
\end{array}$ & $\begin{array}{l}-18.899 \\
(16.820) \\
\end{array}$ & $\begin{array}{c}-26.26 \\
(25.927)\end{array}$ & $\begin{array}{l}-37.97 \\
(22.90)\end{array}$ & $\begin{array}{l}-33.33 \\
(22.11) \\
\end{array}$ \\
\hline Observations & 95 & 95 & 95 & 95 & 95 & 95 \\
\hline $\begin{array}{l}\text { Hansen J-statistic } \\
\text { Hansen J-statistic }\end{array}$ & 0 & 7.58 & 8.53 & 0 & 1.55 & 2.68 \\
\hline $\begin{array}{l}\text { p-value } \\
\text { F-statistics of first } \\
\text { stage }\end{array}$ & 10.58 & 0.108 & 0.046 & 10.58 & 0.817 & 0.883 \\
\hline
\end{tabular}

Notes: The table reports the results of Lewbel model regression, of financial literacy on use of financial services. Columns (1) and (4) show results for standard IV regressions. Columns (2) and (5) show results of regressions using generated instruments only, columns (3) and (6) show results regressions using a combination of generated and external instruments. 


\begin{tabular}{|c|c|c|c|c|}
\hline & $\begin{array}{c}(1) \\
\text { Account } \\
\text { ownership }\end{array}$ & $\begin{array}{c}\text { (2) } \\
\text { Debit card } \\
\text { ownership }\end{array}$ & $\begin{array}{c}\text { (3) } \\
\text { Saved at } \\
\text { formal fin. } \\
\text { institution }\end{array}$ & $\begin{array}{l}\text { (4) } \\
\text { Used debit } \\
\text { card in the } \\
\text { last year }\end{array}$ \\
\hline Financial literacy & $\begin{array}{c}0.520 * * * \\
(0.165)\end{array}$ & $\begin{array}{l}0.428 * * \\
(0.171)\end{array}$ & $\begin{array}{c}0.449 * * * \\
(0.084)\end{array}$ & $\begin{array}{c}0.546 * * * \\
(0.161)\end{array}$ \\
\hline Log GDP p.c. (PPP) & $\begin{array}{c}0.684 * * * \\
(0.165)\end{array}$ & $\begin{array}{c}0.777 * * * \\
(0.178)\end{array}$ & $\begin{array}{l}0.190^{*} \\
(0.100)\end{array}$ & $\begin{array}{c}0.634 * * * \\
(0.169)\end{array}$ \\
\hline $\begin{array}{l}\text { Interaction financial literacy } \\
\text { and log GDP p.c. (PPP) }\end{array}$ & $\begin{array}{c}-0.015 * * \\
(0.006)\end{array}$ & $\begin{array}{l}-0.003 \\
(0.007)\end{array}$ & $\begin{array}{c}0.019 * * * \\
(0.005)\end{array}$ & $\begin{array}{l}0.013^{*} \\
(0.006)\end{array}$ \\
\hline Population share between 15-64 & $\begin{array}{c}0.010 \\
(0.357)\end{array}$ & $\begin{array}{l}-0.134 \\
(0.277)\end{array}$ & $\begin{array}{l}-0.251 \\
(0.209)\end{array}$ & $\begin{array}{l}-0.281 \\
(0.292)\end{array}$ \\
\hline Secondary education & $\begin{array}{c}0.145 \\
(0.107)\end{array}$ & $\begin{array}{l}0.170^{*} \\
(0.097)\end{array}$ & $\begin{array}{c}0.031 \\
(0.072)\end{array}$ & $\begin{array}{c}0.107 \\
(0.083)\end{array}$ \\
\hline Tertiary education & $\begin{array}{l}-0.189 \\
(0.144)\end{array}$ & $\begin{array}{l}-0.134 \\
(0.181)\end{array}$ & $\begin{array}{l}-0.106 \\
(0.110)\end{array}$ & $\begin{array}{c}0.014 \\
(0.169)\end{array}$ \\
\hline Private credit to GDP & $\begin{array}{c}0.149 * * * \\
(0.032)\end{array}$ & $\begin{array}{l}0.100 * * \\
(0.042)\end{array}$ & $\begin{array}{c}0.107 * * * \\
(0.038)\end{array}$ & $\begin{array}{c}0.042 \\
(0.037)\end{array}$ \\
\hline Bank branches per 1000 km² & $\begin{array}{c}0.057 * * * \\
(0.018)\end{array}$ & $\begin{array}{c}0.029 \\
(0.023)\end{array}$ & $\begin{array}{l}0.030 * * \\
(0.013)\end{array}$ & $\begin{array}{c}0.023 \\
(0.025)\end{array}$ \\
\hline Strength of legal rights index & $\begin{array}{c}0.003 \\
(0.546)\end{array}$ & $\begin{array}{c}-0.368 \\
(0.480)\end{array}$ & $\begin{array}{l}-0.283 \\
(0.380)\end{array}$ & $\begin{array}{l}-0.129 \\
(0.421)\end{array}$ \\
\hline Ease of doing business index & $\begin{array}{c}-0.158^{* * *} \\
(0.050)\end{array}$ & $\begin{array}{c}-0.168^{* * *} \\
(0.051)\end{array}$ & $\begin{array}{c}-0.066 * \\
(0.035)\end{array}$ & $\begin{array}{c}-0.135^{* *} \\
(0.054)\end{array}$ \\
\hline Constant & $\begin{array}{c}55.114 * * \\
(24.191) \\
\end{array}$ & $\begin{array}{c}51.277^{* *} \\
(20.057) \\
\end{array}$ & $\begin{array}{c}35.807 * * \\
(15.263) \\
\end{array}$ & $\begin{array}{c}47.168 * * \\
(23.407) \\
\end{array}$ \\
\hline $\mathrm{R}^{2}$ & 0.790 & 0.815 & 0.773 & 0.799 \\
\hline Observations & 119 & 119 & 119 & 119 \\
\hline
\end{tabular}

Notes: The table shows the effect of financial literacy, log GDP per capita and their interaction on different measures of financial inclusion, including access to and use of financial services. Robust standard errors in parentheses. The interacted variables were centered at their means which correspond to about 6041,35 PPP USD for GDP per capita (re-converted to real values) and $36.4 \%$ for financial literacy. ${ }^{* * *}$, ${ }^{* *}$ and $*$ denote significance at the $1 \%, 5 \%$ and $10 \%$ levels, respectively. 
Table 11: Financial literacy and financial inclusion for different income groups

\begin{tabular}{|c|c|c|c|c|c|c|c|c|}
\hline & $\begin{array}{c}\text { (1) } \\
\text { Account } \\
\text { ownership } \\
\text { Bottom 40\% }\end{array}$ & $\begin{array}{c}\text { (2) } \\
\text { Account } \\
\text { ownership } \\
\text { Top 60\% }\end{array}$ & $\begin{array}{c}\text { (3) } \\
\text { Debit card } \\
\text { ownership } \\
\text { Bottom 40\% }\end{array}$ & $\begin{array}{c}\text { (4) } \\
\text { Debit card } \\
\text { ownership } \\
\text { Top 60\% }\end{array}$ & $\begin{array}{c}\text { (5) } \\
\text { Saved at } \\
\text { formal fin. } \\
\text { institution } \\
\text { Bottom 40\% }\end{array}$ & $\begin{array}{c}\text { (6) } \\
\text { Saved at } \\
\text { formal fin. } \\
\text { institution } \\
\text { Top 60\% }\end{array}$ & $\begin{array}{c}\text { (7) } \\
\text { Used debit } \\
\text { card in the } \\
\text { last year } \\
\text { Bottom 40\% }\end{array}$ & $\begin{array}{c}(8) \\
\text { Used debit } \\
\text { card in the } \\
\text { last year } \\
\text { Top 60\% }\end{array}$ \\
\hline FL bottom $40 \%$ & $\begin{array}{c}0.426^{* * *} \\
(0.148)\end{array}$ & & $\begin{array}{c}0.500 * * * \\
(0.139)\end{array}$ & & $\begin{array}{l}0.360 * * \\
(0.145)\end{array}$ & & $\begin{array}{c}0.649 * * * \\
(0.136)\end{array}$ & \\
\hline FL top $60 \%$ & & $\begin{array}{c}0.530 * * * \\
(0.134)\end{array}$ & & $\begin{array}{c}0.508^{* * *} \\
(0.129)\end{array}$ & & $\begin{array}{c}0.442 * * * \\
(0.145)\end{array}$ & & $\begin{array}{c}0.689 * * * \\
(0.136)\end{array}$ \\
\hline Log GDP p.c. (PPP) & $\begin{array}{c}14.073^{* * *} \\
(2.965)\end{array}$ & $\begin{array}{c}12.864 * * * \\
(2.670)\end{array}$ & $\begin{array}{c}13.587 * * * \\
(2.784)\end{array}$ & $\begin{array}{c}14.340^{* * * *} \\
(2.581)\end{array}$ & $\begin{array}{c}2.203 \\
(2.917)\end{array}$ & $\begin{array}{c}3.291 \\
(2.894)\end{array}$ & $\begin{array}{c}10.725 * * * \\
(2.732)\end{array}$ & $\begin{array}{c}13.360 * * * \\
(2.709)\end{array}$ \\
\hline Population share between15-64 & $\begin{array}{l}-0.537 \\
(0.347)\end{array}$ & $\begin{array}{l}-0.066 \\
(0.316)\end{array}$ & $\begin{array}{c}-0.760 * * \\
(0.326)\end{array}$ & $\begin{array}{l}-0.314 \\
(0.306)\end{array}$ & $\begin{array}{c}-0.849 * * \\
(0.342)\end{array}$ & $\begin{array}{c}-0.769 * * \\
(0.343)\end{array}$ & $\begin{array}{c}-0.885 * * * \\
(0.320)\end{array}$ & $\begin{array}{l}-0.628^{*} \\
(0.321)\end{array}$ \\
\hline Secondary education & $\begin{array}{c}0.019 \\
(0.117)\end{array}$ & $\begin{array}{c}0.018 \\
(0.103)\end{array}$ & $\begin{array}{c}0.036 \\
(0.110)\end{array}$ & $\begin{array}{c}0.024 \\
(0.100)\end{array}$ & $\begin{array}{c}0.002 \\
(0.116)\end{array}$ & $\begin{array}{l}-0.045 \\
(0.112)\end{array}$ & $\begin{array}{c}0.005 \\
(0.108)\end{array}$ & $\begin{array}{l}-0.053 \\
(0.105)\end{array}$ \\
\hline Tertiary education & $\begin{array}{l}-0.035 \\
(0.164)\end{array}$ & $\begin{array}{l}-0.223 \\
(0.143)\end{array}$ & $\begin{array}{c}0.161 \\
(0.154)\end{array}$ & $\begin{array}{l}-0.055 \\
(0.139)\end{array}$ & $\begin{array}{c}0.156 \\
(0.162)\end{array}$ & $\begin{array}{l}-0.005 \\
(0.155)\end{array}$ & $\begin{array}{l}0.359 * * \\
(0.151)\end{array}$ & $\begin{array}{c}0.165 \\
(0.146)\end{array}$ \\
\hline Private credit to GDP & $\begin{array}{c}0.158 * * * \\
(0.043)\end{array}$ & $\begin{array}{c}0.111 * * * \\
(0.038)\end{array}$ & $\begin{array}{c}0.096^{* *} \\
(0.040)\end{array}$ & $\begin{array}{c}0.091 * * \\
(0.037)\end{array}$ & $\begin{array}{c}0.127 * * * \\
(0.042)\end{array}$ & $\begin{array}{c}0.108^{* *} \\
(0.041)\end{array}$ & $\begin{array}{c}0.046 \\
(0.040)\end{array}$ & $\begin{array}{c}0.046 \\
(0.039)\end{array}$ \\
\hline Bank branches per 1000 km² & $\begin{array}{l}0.059 * \\
(0.033)\end{array}$ & $\begin{array}{c}0.058^{* *} \\
(0.029)\end{array}$ & $\begin{array}{c}0.030 \\
(0.031)\end{array}$ & $\begin{array}{c}0.037 \\
(0.028)\end{array}$ & $\begin{array}{c}0.014 \\
(0.032)\end{array}$ & $\begin{array}{c}0.025 \\
(0.031)\end{array}$ & $\begin{array}{c}0.018 \\
(0.030)\end{array}$ & $\begin{array}{c}0.037 \\
(0.029)\end{array}$ \\
\hline Strength of legal rights index & $\begin{array}{c}0.247 \\
(0.605)\end{array}$ & $\begin{array}{c}0.375 \\
(0.534)\end{array}$ & $\begin{array}{l}-0.035 \\
(0.568)\end{array}$ & $\begin{array}{c}0.038 \\
(0.516)\end{array}$ & $\begin{array}{c}0.737 \\
(0.596)\end{array}$ & $\begin{array}{c}0.643 \\
(0.578)\end{array}$ & $\begin{array}{c}0.394 \\
(0.558)\end{array}$ & $\begin{array}{c}0.298 \\
(0.542)\end{array}$ \\
\hline Ease of doing business index & $\begin{array}{c}-0.137 * * \\
(0.057)\end{array}$ & $\begin{array}{l}-0.079 \\
(0.051)\end{array}$ & $\begin{array}{c}-0.122 * * \\
(0.054)\end{array}$ & $\begin{array}{l}-0.094 * \\
(0.049)\end{array}$ & $\begin{array}{c}0.033 \\
(0.056)\end{array}$ & $\begin{array}{c}0.033 \\
(0.055)\end{array}$ & $\begin{array}{l}-0.081 \\
(0.053)\end{array}$ & $\begin{array}{l}-0.071 \\
(0.052)\end{array}$ \\
\hline Constant & $\begin{array}{c}-63.114^{* *} \\
(31.726)\end{array}$ & $\begin{array}{c}-77.057 * * * \\
(28.073)\end{array}$ & $\begin{array}{c}-61.545^{* *} \\
(29.782)\end{array}$ & $\begin{array}{c}-87.831 * * * \\
(27.147)\end{array}$ & $\begin{array}{c}49.882 \\
(31.207)\end{array}$ & $\begin{array}{c}47.887 \\
(30.428)\end{array}$ & $\begin{array}{l}-46.158 \\
(29.226)\end{array}$ & $\begin{array}{c}-78.765^{* * *} \\
(28.488)\end{array}$ \\
\hline Test $40 \%=$ top $60 \%$ (p-values) & \multicolumn{2}{|c|}{0.3085} & \multicolumn{2}{|c|}{0.9258} & \multicolumn{2}{|c|}{0.3871} & \multicolumn{2}{|c|}{0.6039} \\
\hline $\begin{array}{l}\mathrm{R}^{2} \\
\text { Observations }\end{array}$ & $\begin{array}{c}0.789 \\
119\end{array}$ & $\begin{array}{c}0.797 \\
119\end{array}$ & $\begin{array}{c}0.782 \\
119\end{array}$ & $\begin{array}{c}0.821 \\
119\end{array}$ & $\begin{array}{c}0.312 \\
119\end{array}$ & $\begin{array}{c}0.352 \\
119\end{array}$ & $\begin{array}{c}0.734 \\
119\end{array}$ & $\begin{array}{c}0.793 \\
119\end{array}$ \\
\hline
\end{tabular}

Notes: The table shows OLS results with standard errors in parentheses. $* * *, * *$ and $*$ denote significance at the $1 \%, 5 \%$ and $10 \%$ levels, respectively. 
Table 12 : Financial literacy and financial inclusion for women and men

\begin{tabular}{|c|c|c|c|c|c|c|c|c|}
\hline & $\begin{array}{c}\text { (1) } \\
\text { Account } \\
\text { ownership } \\
\text { Women }\end{array}$ & $\begin{array}{c}\text { (2) } \\
\text { Account } \\
\text { ownership } \\
\text { Men } \\
\end{array}$ & $\begin{array}{c}\text { (3) } \\
\text { Debit card } \\
\text { ownership } \\
\text { Women }\end{array}$ & $\begin{array}{c}\text { (4) } \\
\text { Debit card } \\
\text { ownership } \\
\text { Men } \\
\end{array}$ & $\begin{array}{c}\text { (5) } \\
\text { Saved at } \\
\text { formal fin. } \\
\text { institution } \\
\text { Women }\end{array}$ & $\begin{array}{c}\text { (6) } \\
\text { Saved at } \\
\text { formal fin. } \\
\text { institution } \\
\text { Men } \\
\end{array}$ & $\begin{array}{c}(7) \\
\text { Used debit } \\
\text { card in the } \\
\text { last year } \\
\text { Women }\end{array}$ & $\begin{array}{c}\text { (8) } \\
\text { Used debit } \\
\text { card in the } \\
\text { last year } \\
\text { Men }\end{array}$ \\
\hline FL - women & $\begin{array}{c}0.556 * * * \\
(0.146)\end{array}$ & & $\begin{array}{c}0.578 * * * \\
(0.138)\end{array}$ & & $\begin{array}{c}0.475^{* * *} \\
(0.147)\end{array}$ & & $\begin{array}{c}0.685^{* * *} \\
(0.140)\end{array}$ & \\
\hline FL - men & & $\begin{array}{c}0.434 * * * \\
(0.132)\end{array}$ & & $\begin{array}{c}0.417 * * * \\
(0.126)\end{array}$ & & $\begin{array}{c}0.346 * * \\
(0.143)\end{array}$ & & $\begin{array}{c}0.619 * * * \\
(0.130)\end{array}$ \\
\hline Log GDP p.c. (PPP) & $\begin{array}{c}12.489 * * * \\
(2.823)\end{array}$ & $\begin{array}{c}14.200 * * * \\
(2.708)\end{array}$ & $\begin{array}{c}12.793 * * * \\
(2.673)\end{array}$ & $\begin{array}{c}15.482 * * * \\
(2.592)\end{array}$ & $\begin{array}{c}1.823 \\
(2.843)\end{array}$ & $\begin{array}{c}3.912 \\
(2.934)\end{array}$ & $\begin{array}{c}11.888 * * * \\
(2.715)\end{array}$ & $\begin{array}{c}13.049 * * * \\
(2.675)\end{array}$ \\
\hline Population share between15-64 & $\begin{array}{l}-0.325 \\
(0.336)\end{array}$ & $\begin{array}{l}-0.251 \\
(0.316)\end{array}$ & $\begin{array}{l}-0.614 * \\
(0.318)\end{array}$ & $\begin{array}{l}-0.466 \\
(0.302)\end{array}$ & $\begin{array}{c}-0.791 * * \\
(0.339)\end{array}$ & $\begin{array}{c}-0.855^{* *} \\
(0.342)\end{array}$ & $\begin{array}{c}-0.871 * * * \\
(0.323)\end{array}$ & $\begin{array}{c}-0.698 * * \\
(0.312)\end{array}$ \\
\hline Secondary education & $\begin{array}{c}0.062 \\
(0.111)\end{array}$ & $\begin{array}{l}-0.014 \\
(0.105)\end{array}$ & $\begin{array}{c}0.054 \\
(0.105)\end{array}$ & $\begin{array}{c}0.016 \\
(0.101)\end{array}$ & $\begin{array}{c}0.010 \\
(0.112)\end{array}$ & $\begin{array}{c}-0.056 \\
(0.114)\end{array}$ & $\begin{array}{l}-0.015 \\
(0.107)\end{array}$ & $\begin{array}{l}-0.033 \\
(0.104)\end{array}$ \\
\hline Tertiary education & $\begin{array}{l}-0.151 \\
(0.155)\end{array}$ & $\begin{array}{l}-0.186 \\
(0.147)\end{array}$ & $\begin{array}{c}0.039 \\
(0.146)\end{array}$ & $\begin{array}{l}-0.018 \\
(0.140)\end{array}$ & $\begin{array}{c}0.068 \\
(0.156)\end{array}$ & $\begin{array}{c}0.033 \\
(0.159)\end{array}$ & $\begin{array}{l}0.272^{*} \\
(0.149)\end{array}$ & $\begin{array}{c}0.183 \\
(0.145)\end{array}$ \\
\hline Private credit to GDP & $\begin{array}{c}0.140 * * * \\
(0.041)\end{array}$ & $\begin{array}{c}0.126 * * * \\
(0.039)\end{array}$ & $\begin{array}{c}0.104 * * * \\
(0.039)\end{array}$ & $\begin{array}{c}0.089 * * \\
(0.037)\end{array}$ & $\begin{array}{c}0.125^{* * *} \\
(0.041)\end{array}$ & $\begin{array}{c}0.110^{* * *} \\
(0.042)\end{array}$ & $\begin{array}{c}0.059 \\
(0.039)\end{array}$ & $\begin{array}{c}0.040 \\
(0.038)\end{array}$ \\
\hline Bank branches per 1000 km² & $\begin{array}{c}0.063 * * \\
(0.031)\end{array}$ & $\begin{array}{l}0.057^{*} \\
(0.029)\end{array}$ & $\begin{array}{c}0.034 \\
(0.029)\end{array}$ & $\begin{array}{c}0.038 \\
(0.028)\end{array}$ & $\begin{array}{c}0.017 \\
(0.031)\end{array}$ & $\begin{array}{c}0.025 \\
(0.032)\end{array}$ & $\begin{array}{c}0.030 \\
(0.030)\end{array}$ & $\begin{array}{c}0.032 \\
(0.029)\end{array}$ \\
\hline Strength of legal rights index & $\begin{array}{c}0.381 \\
(0.572)\end{array}$ & $\begin{array}{c}0.292 \\
(0.545)\end{array}$ & $\begin{array}{c}0.137 \\
(0.542)\end{array}$ & $\begin{array}{l}-0.076 \\
(0.521)\end{array}$ & $\begin{array}{c}0.640 \\
(0.576)\end{array}$ & $\begin{array}{c}0.746 \\
(0.590)\end{array}$ & $\begin{array}{c}0.521 \\
(0.550)\end{array}$ & $\begin{array}{c}0.205 \\
(0.538)\end{array}$ \\
\hline Ease of doing business index & $\begin{array}{c}-0.123^{* *} \\
(0.055)\end{array}$ & $\begin{array}{c}-0.088^{*} \\
(0.051)\end{array}$ & $\begin{array}{c}-0.120^{* *} \\
(0.052)\end{array}$ & $\begin{array}{c}-0.095^{*} \\
(0.049)\end{array}$ & $\begin{array}{c}0.034 \\
(0.055)\end{array}$ & $\begin{array}{c}0.029 \\
(0.056)\end{array}$ & $\begin{array}{l}-0.076 \\
(0.053)\end{array}$ & $\begin{array}{l}-0.081 \\
(0.051)\end{array}$ \\
\hline Constant & $\begin{array}{c}-63.833^{* *} \\
(30.229)\end{array}$ & $\begin{array}{c}-74.712 * * * \\
(28.461) \\
\end{array}$ & $\begin{array}{c}-62.945^{* *} \\
(28.622)\end{array}$ & $\begin{array}{c}-86.730 * * * \\
(27.242)\end{array}$ & $\begin{array}{l}52.539 * \\
(30.444) \\
\end{array}$ & $\begin{array}{c}47.549 \\
(30.837)\end{array}$ & $\begin{array}{l}-55.676^{*} \\
(29.070)\end{array}$ & $\begin{array}{c}-70.451^{* *} \\
(28.115)\end{array}$ \\
\hline Test women = men (p-values) & \multicolumn{2}{|c|}{0.1916} & \multicolumn{2}{|c|}{ 0.0791* } & \multicolumn{2}{|c|}{$0.0879 *$} & \multicolumn{2}{|c|}{0.3929} \\
\hline $\begin{array}{l}\mathrm{R}^{2} \\
\text { Observations }\end{array}$ & $\begin{array}{c}0.800 \\
119\end{array}$ & $\begin{array}{c}0.791 \\
119\end{array}$ & $\begin{array}{c}0.805 \\
119\end{array}$ & $\begin{array}{c}0.811 \\
119\end{array}$ & $\begin{array}{c}0.358 \\
119\end{array}$ & $\begin{array}{c}0.318 \\
119\end{array}$ & $\begin{array}{c}0.769 \\
119\end{array}$ & $\begin{array}{c}0.774 \\
119\end{array}$ \\
\hline
\end{tabular}




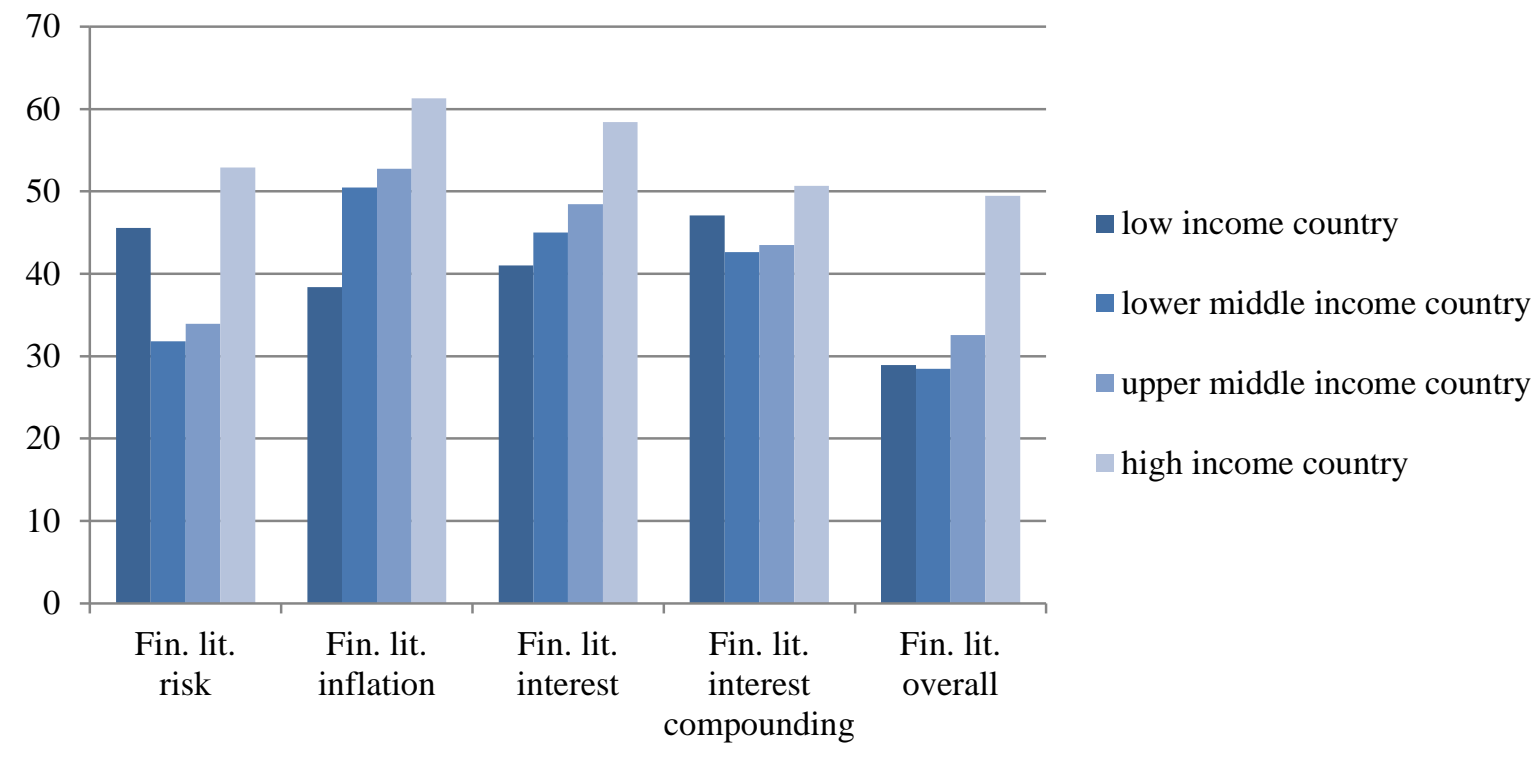

Figure 1: Financial literacy concepts at income groupings

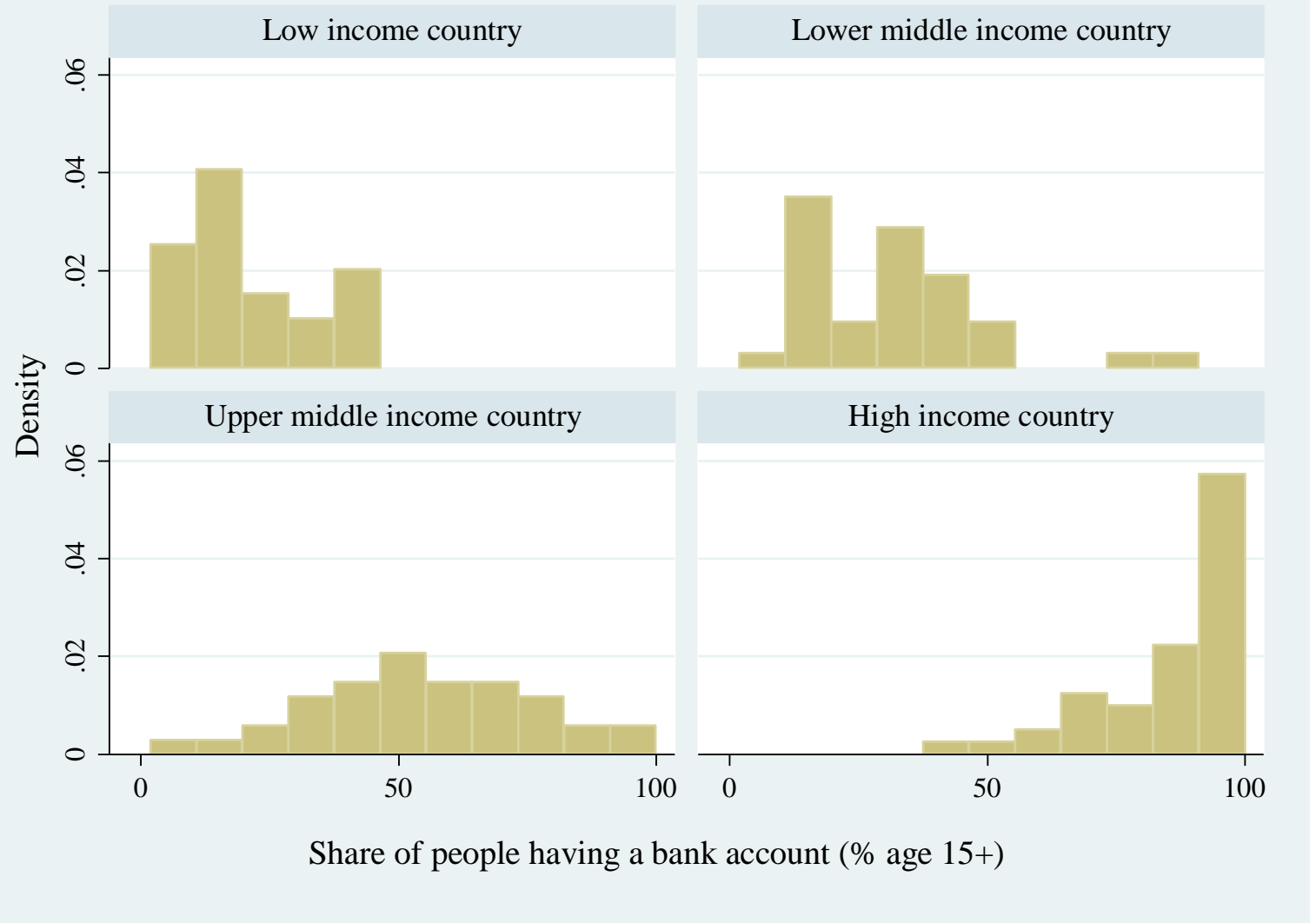

Figure 2: Having an account by World Bank income classification 
Average marginal effects of centered fin. lit. with $95 \%$ CIs
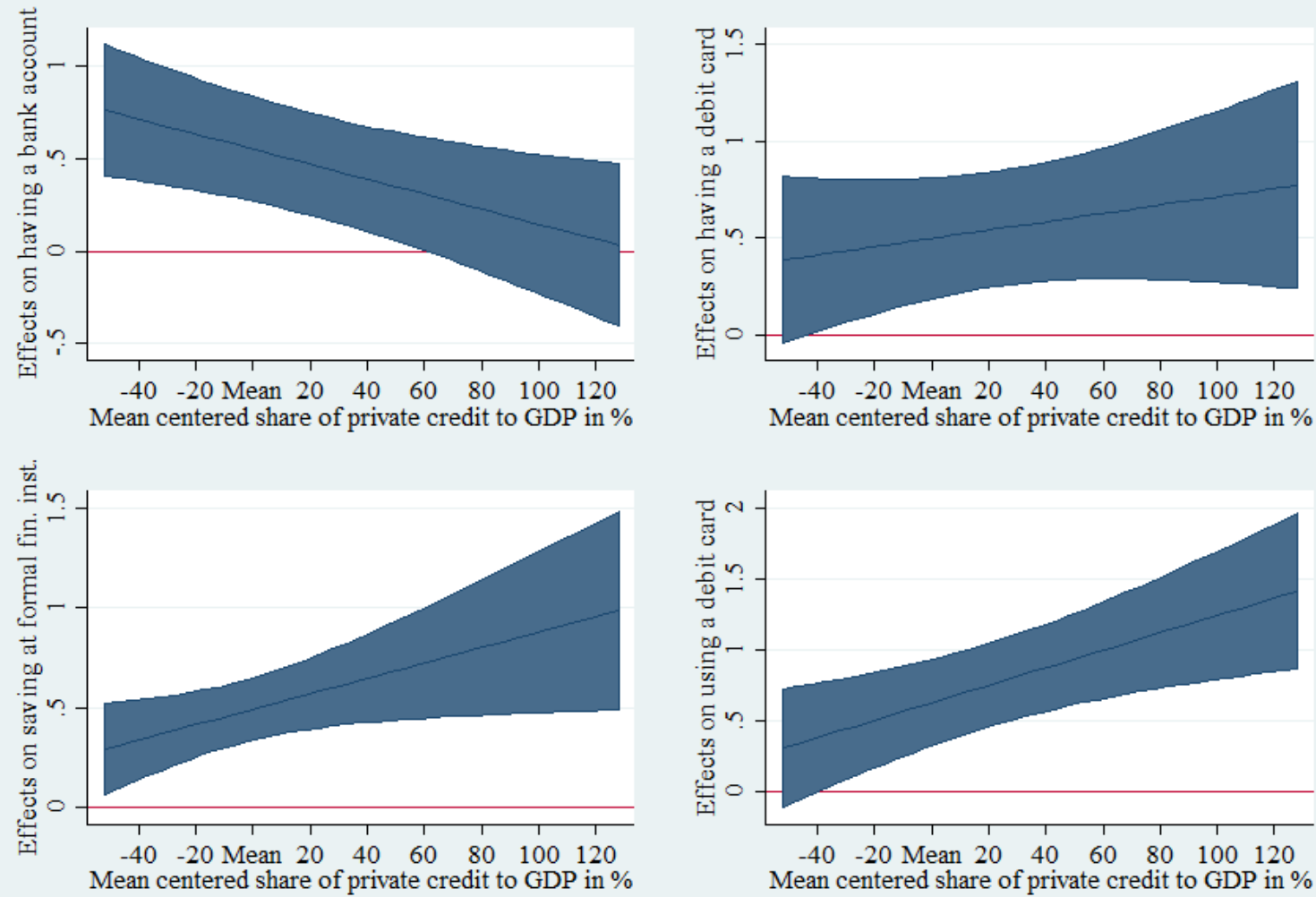

Figure 3: Average marginal effects of financial literacy on four measures of financial inclusion at different levels of private credit to GDP 
Average marginal effects of centered fin. lit. with $95 \%$ CIs
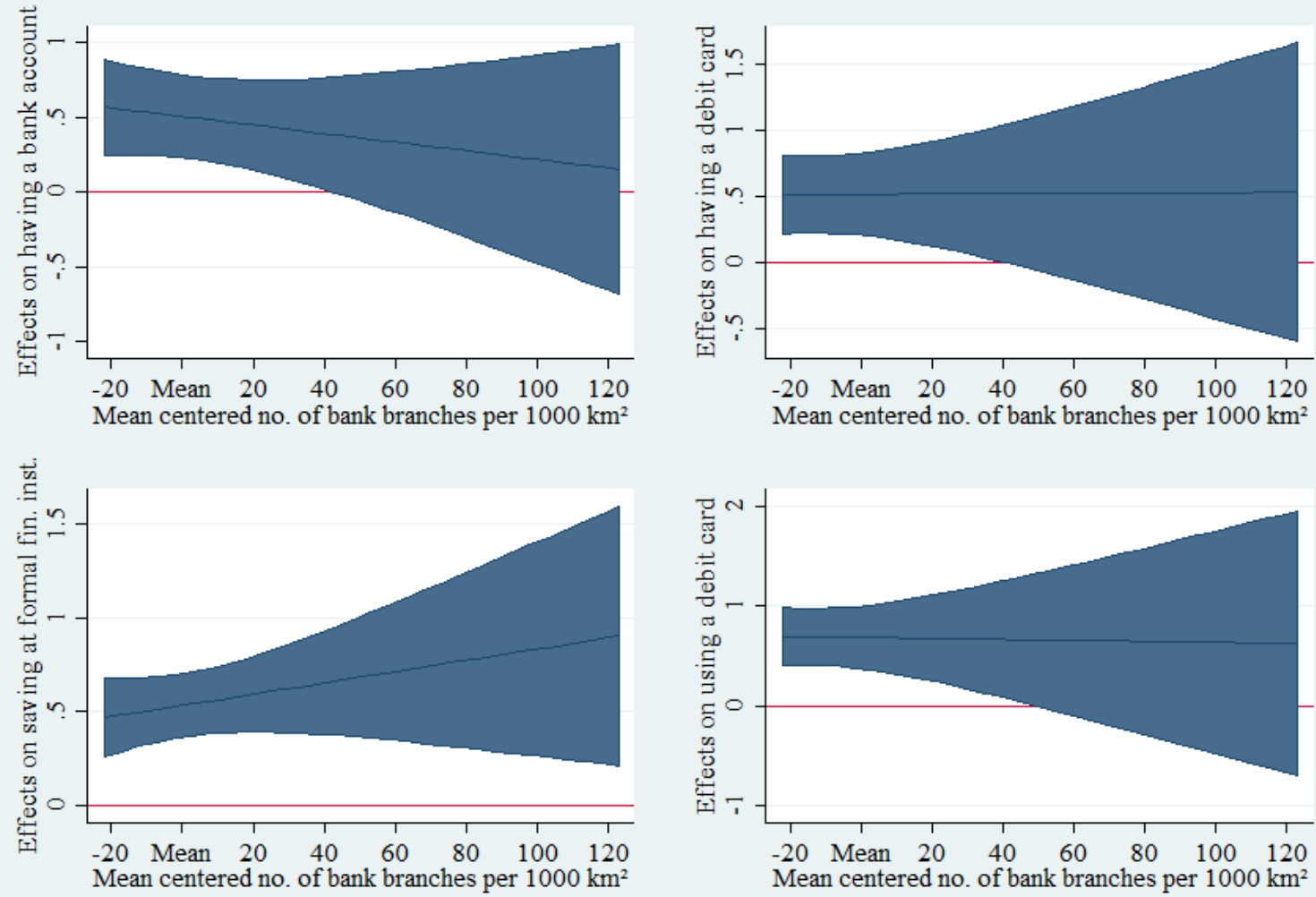

Figure 4: Average marginal effects of financial literacy on four measures of financial inclusion at different levels of bank branches per 1000 km2 
Average marginal effects of centered fin. lit. with $95 \%$ CIs
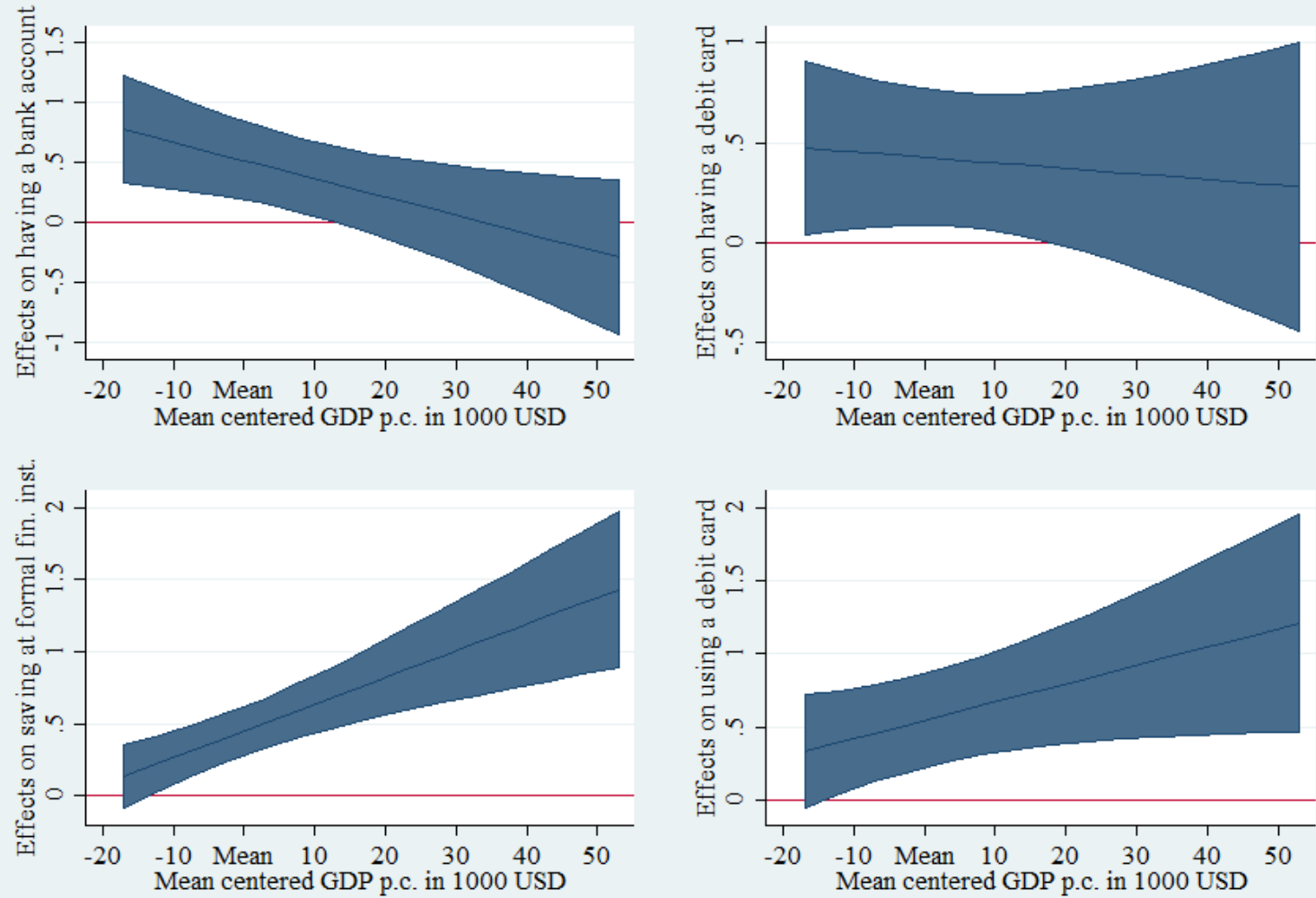

Figure 5: Average marginal effect of financial literacy on four measures of financial inclusion at different levels of GDP per capita 


\section{APPENDIX}

to complement

“Does Financial Literacy Improve Financial Inclusion?

Cross Country Evidence” 
Table A1: Control variables summary statistics and sources

\begin{tabular}{|c|c|c|c|c|c|c|c|}
\hline & Mean & SD & Min & $\operatorname{Max}$ & Count & Description & Source \\
\hline GDP per capita & 18230.11 & 17862.26 & 711 & 91368 & 136 & $\begin{array}{l}\text { GDP per capita purchasing } \\
\text { power parity, constant } \\
2011 \text { USD }\end{array}$ & $\begin{array}{l}\text { World Bank, } \\
\text { World Development } \\
\text { Indicators } 2014\end{array}$ \\
\hline Secondary education & 0.51 & 0.16 & 0 & 1 & 142 & $\begin{array}{l}\text { Proportion of population } \\
\text { that has completed } \\
\text { secondary school }\end{array}$ & $\begin{array}{l}\text { World Bank, Global } \\
\text { Findex } 2014\end{array}$ \\
\hline Tertiary education & 0.16 & 0.14 & 0 & 1 & 142 & $\begin{array}{l}\text { Proportion of population } \\
\text { that has completed tertiary } \\
\text { education }\end{array}$ & $\begin{array}{l}\text { World Bank, Global } \\
\text { Findex } 2014\end{array}$ \\
\hline Private credit to GDP & 60.50 & 48.06 & 4 & 260 & 126 & $\begin{array}{l}\text { Private credit by deposit } \\
\text { money banks and other } \\
\text { financial institutions to } \\
\text { GDP, designed to measure } \\
\text { financial depth }\end{array}$ & $\begin{array}{c}\text { World Bank, } \\
\text { Global Financial } \\
\text { Development } 2014\end{array}$ \\
\hline Ease of doing business index & 85.39 & 55.41 & 1 & 187 & 140 & $\begin{array}{l}\text { Ease of doing business } \\
\text { ranks economies from } 1 \text { to } \\
\text { 190, with first place being } \\
\text { the best. A high ranking (a } \\
\text { low numerical rank) means } \\
\text { that the regulatory } \\
\text { environment is conducive } \\
\text { to business operation. }\end{array}$ & $\begin{array}{l}\text { World Bank, } \\
\text { World Development } \\
\text { Indicators } 2014\end{array}$ \\
\hline
\end{tabular}


Political Risk Rating ICRG 2012

Branches of commercial banks per $1,000 \mathrm{~km}^{2}$

Automated Teller Machines (ATMs)

per $1,000 \mathrm{~km}^{2}$
64.57

12.77

23

90

37.55

137.83

89.91

362.60

0

1382

3870
129

121 Measures the political stability of a country along

12 dimensions, e.g.

corruption, government

stability, and bureaucracy quality.

Number of branches per

$$
1000 \mathrm{~km} 2
$$

ATMs per $1000 \mathrm{~km} 2$
ICRG 2012

IMF, Financial Access Survey 2014

IMF, Financial Access Survey 2014 
Table A2: Correlations between control variables

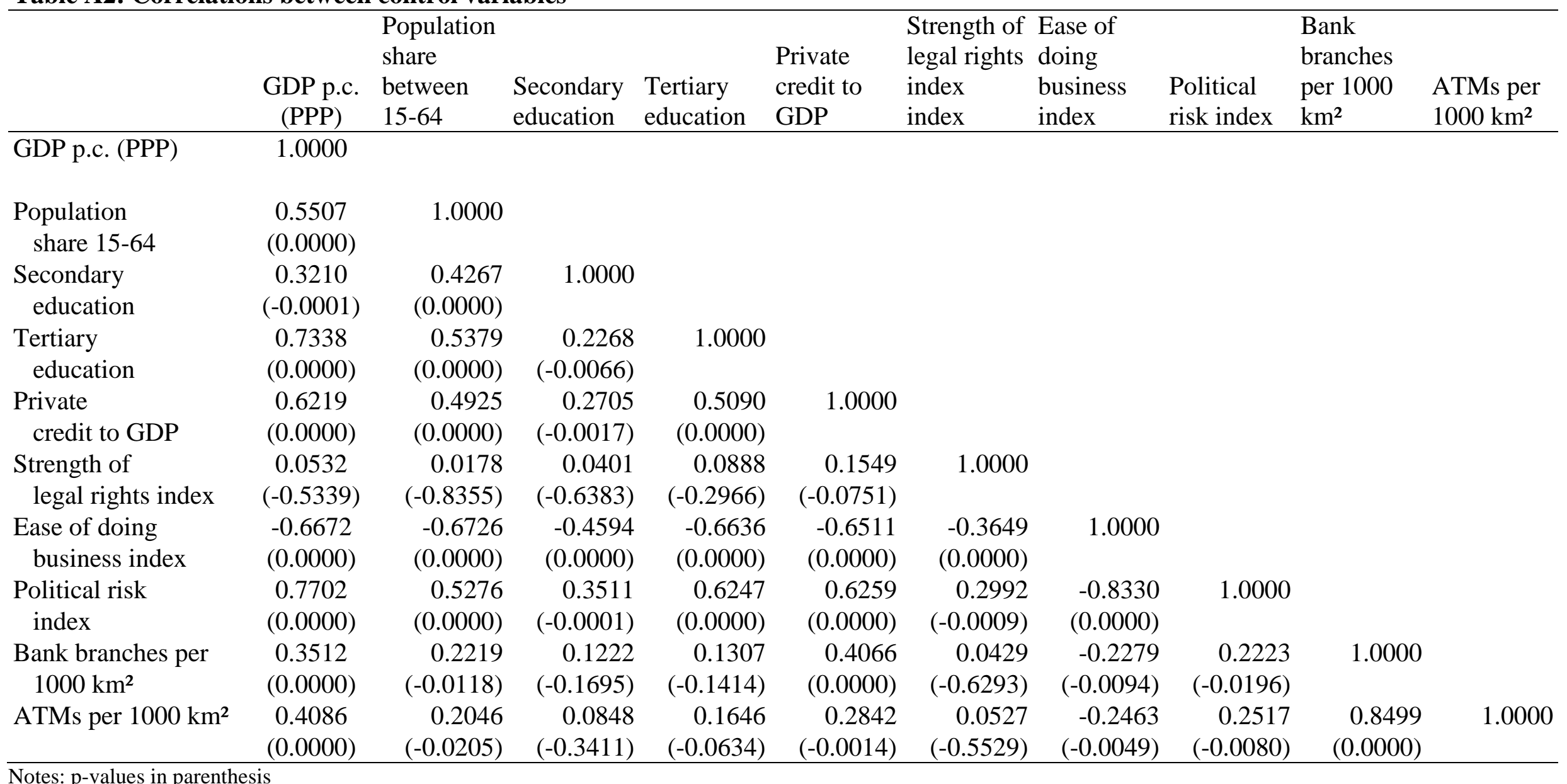

Notes: p-values in parenthesis 
Table A3: List of countries in OLS and IV regressions

\begin{tabular}{|c|c|c|c|c|c|c|c|c|}
\hline Country & $\begin{array}{l}\text { OLS } \\
\text { sample }\end{array}$ & $\begin{array}{l}\text { IV } \\
\text { sample }\end{array}$ & Country & $\begin{array}{l}\text { OLS } \\
\text { sample }\end{array}$ & $\begin{array}{l}\text { IV } \\
\text { sample }\end{array}$ & Country & $\begin{array}{l}\text { OLS } \\
\text { sample }\end{array}$ & $\begin{array}{l}\text { IV } \\
\text { sample }\end{array}$ \\
\hline Afghanistan & $\mathrm{x}$ & & Greece & $\mathrm{x}$ & $\mathrm{x}$ & Pakistan & $\mathrm{x}$ & \\
\hline Albania & $\mathrm{x}$ & $\mathrm{X}$ & Guatemala & $\mathrm{x}$ & $\mathrm{x}$ & Panama & $\mathrm{x}$ & $\mathrm{x}$ \\
\hline Algeria & $\mathrm{X}$ & $\mathrm{X}$ & Guinea & $\mathrm{X}$ & & Peru & $\mathrm{x}$ & $\mathrm{x}$ \\
\hline Angola & $\mathrm{X}$ & & Honduras & $\mathrm{X}$ & $\mathrm{x}$ & Philippines & $\mathrm{x}$ & $\mathrm{x}$ \\
\hline Argentina & $\mathrm{x}$ & $\mathrm{x}$ & Hungary & $\mathrm{x}$ & $\mathrm{x}$ & Poland & $\mathrm{x}$ & $\mathrm{x}$ \\
\hline Armenia & $\mathrm{X}$ & $\mathrm{X}$ & India & $\mathrm{x}$ & & Portugal & $\mathrm{x}$ & $\mathrm{x}$ \\
\hline Australia & $\mathrm{x}$ & $\mathrm{x}$ & Indonesia & $\mathrm{X}$ & $\mathrm{x}$ & Romania & $\mathrm{x}$ & \\
\hline Austria & $\mathrm{X}$ & $\mathrm{X}$ & Iraq & $\mathrm{x}$ & & Russian Federation & $\mathrm{x}$ & $\mathrm{x}$ \\
\hline Azerbaijan & $\mathrm{x}$ & $\mathrm{x}$ & Ireland & $\mathrm{x}$ & $\mathrm{x}$ & Saudi Arabia & $\mathrm{x}$ & $\mathrm{x}$ \\
\hline Bangladesh & $\mathrm{x}$ & $\mathrm{X}$ & Israel & $\mathrm{x}$ & $\mathrm{X}$ & Senegal & $\mathrm{x}$ & \\
\hline Belgium & $\mathrm{X}$ & $\mathrm{X}$ & Italy & $\mathrm{X}$ & $\mathrm{X}$ & Serbia & $\mathrm{x}$ & \\
\hline Belize & $\mathrm{x}$ & & Jamaica & $\mathrm{x}$ & & Slovak Republic & $\mathrm{x}$ & $\mathrm{x}$ \\
\hline Benin & $\mathrm{X}$ & & Japan & $\mathrm{X}$ & $\mathrm{x}$ & Slovenia & $\mathrm{x}$ & $\mathrm{x}$ \\
\hline Bhutan & $\mathrm{x}$ & & Jordan & $\mathrm{x}$ & $\mathrm{X}$ & South Africa & $\mathrm{x}$ & $\mathrm{x}$ \\
\hline Bolivia & $\mathrm{X}$ & $\mathrm{X}$ & Kazakhstan & $\mathrm{X}$ & $\mathrm{X}$ & Spain & $\mathrm{x}$ & $\mathrm{x}$ \\
\hline Bosnia and Herz. & $\mathrm{X}$ & $\mathrm{X}$ & Kenya & $\mathrm{x}$ & $\mathrm{X}$ & Sri Lanka & $\mathrm{x}$ & \\
\hline Botswana & $\mathrm{X}$ & $\mathrm{X}$ & Korea, Rep. & $\mathrm{X}$ & $\mathrm{X}$ & Sudan & $\mathrm{x}$ & \\
\hline Brazil & $\mathrm{X}$ & $\mathrm{X}$ & Kuwait & $\mathrm{x}$ & $\mathrm{x}$ & Sweden & $\mathrm{x}$ & $\mathrm{x}$ \\
\hline Bulgaria & $\mathrm{X}$ & $\mathrm{X}$ & Kyrgyz Rep. & $\mathrm{X}$ & $\mathrm{X}$ & Switzerland & $\mathrm{x}$ & $\mathrm{x}$ \\
\hline Burundi & $\mathrm{X}$ & & Latvia & $\mathrm{x}$ & $\mathrm{x}$ & Tanzania & $\mathrm{x}$ & $\mathrm{x}$ \\
\hline Cambodia & $\mathrm{X}$ & & Lebanon & $\mathrm{X}$ & $\mathrm{X}$ & Thailand & $\mathrm{x}$ & $\mathrm{x}$ \\
\hline Cameroon & $\mathrm{x}$ & $\mathrm{X}$ & Luxembourg & $\mathrm{X}$ & $\mathrm{x}$ & Togo & $\mathrm{x}$ & $\mathrm{x}$ \\
\hline Chad & $\mathrm{x}$ & $\mathrm{X}$ & Macedonia, FYR & $\mathrm{X}$ & $\mathrm{x}$ & Tunisia & $\mathrm{x}$ & $\mathrm{x}$ \\
\hline Chile & $\mathrm{X}$ & $\mathrm{X}$ & Madagascar & $\mathrm{X}$ & $\mathrm{X}$ & Turkey & $\mathrm{x}$ & $\mathrm{x}$ \\
\hline China & $\mathrm{X}$ & $\mathrm{X}$ & Malawi & $\mathrm{x}$ & $\mathrm{X}$ & Uganda & $\mathrm{x}$ & $\mathrm{x}$ \\
\hline Colombia & $\mathrm{x}$ & $\mathrm{x}$ & Malaysia & $\mathrm{x}$ & $\mathrm{x}$ & Ukraine & $\mathrm{x}$ & $\mathrm{x}$ \\
\hline Congo, Dem. Rep. & $\mathrm{x}$ & & Mali & $\mathrm{x}$ & $\mathrm{x}$ & United Arab Emirates & $\mathrm{x}$ & \\
\hline Congo, Rep. & $\mathrm{X}$ & & Malta & $\mathrm{x}$ & & United States & $\mathrm{x}$ & $\mathrm{x}$ \\
\hline Costa Rica & $\mathrm{X}$ & $\mathrm{X}$ & Mauritania & $\mathrm{X}$ & $\mathrm{x}$ & Uruguay & $\mathrm{x}$ & $\mathrm{x}$ \\
\hline Cote d'Ivoire & $\mathrm{x}$ & & Mauritius & $\mathrm{x}$ & $\mathrm{x}$ & Venezuela, RB & $\mathrm{x}$ & $\mathrm{x}$ \\
\hline Croatia & $\mathrm{X}$ & $\mathrm{X}$ & Mexico & $\mathrm{X}$ & $\mathrm{X}$ & Vietnam & $\mathrm{x}$ & \\
\hline Cyprus & $\mathrm{x}$ & $\mathrm{x}$ & Moldova & $\mathrm{X}$ & $\mathrm{x}$ & West Bank and Gaza & $\mathrm{x}$ & \\
\hline Czech Republic & $\mathrm{x}$ & $\mathrm{X}$ & Mongolia & $\mathrm{X}$ & & Yemen, Rep. & $\mathrm{x}$ & $\mathrm{x}$ \\
\hline Denmark & $\mathrm{x}$ & $\mathrm{x}$ & Montenegro & $\mathrm{x}$ & $\mathrm{x}$ & Zambia & $\mathrm{x}$ & $\mathrm{x}$ \\
\hline Dom. Republic & $\mathrm{X}$ & $\mathrm{X}$ & Namibia & $\mathrm{X}$ & $\mathrm{X}$ & & & \\
\hline Ecuador & $\mathrm{x}$ & $\mathrm{x}$ & Nepal & $\mathrm{x}$ & & Total & 119 & 93 \\
\hline Egypt, Arab Rep. & $\mathrm{X}$ & $\mathrm{X}$ & Netherlands & $\mathrm{X}$ & $\mathrm{X}$ & & & \\
\hline El Salvador & $\mathrm{x}$ & $\mathrm{X}$ & New Zealand & $\mathrm{x}$ & $\mathrm{X}$ & & & \\
\hline Estonia & $\mathrm{X}$ & $\mathrm{X}$ & Nicaragua & $\mathrm{X}$ & $\mathrm{X}$ & & & \\
\hline Finland & $\mathrm{x}$ & $\mathrm{x}$ & Niger & $\mathrm{x}$ & $\mathrm{X}$ & & & \\
\hline France & $\mathrm{X}$ & $\mathrm{X}$ & Nigeria & $\mathrm{X}$ & $\mathrm{X}$ & & & \\
\hline Georgia & $\mathrm{x}$ & $\mathrm{x}$ & & & & & & \\
\hline Germany & $\mathrm{X}$ & $\mathrm{X}$ & & & & & & \\
\hline Ghana & $\mathrm{X}$ & $\mathrm{X}$ & & & & & & \\
\hline
\end{tabular}


Table A4: Basis for imputations for numeracy in primary school

(1)

Numeracy in primary school

\begin{tabular}{lc} 
& OLS \\
\hline Numeracy in secondary school & $0.749^{* * *}$ \\
& $(0.072)$ \\
Constant & 2.162 \\
& $(3.754)$ \\
\hline $\mathrm{R}^{2}$ & 0.66 \\
Observations & 58 \\
\hline
\end{tabular}

Notes: This table shows the relationship that is the basis for our imputation of numeracy in primary school using numeracy in secondary schools. If numeracy in primary school is missing, but numeracy in secondary school is available the following equation was used to generate an imputation for numeracy in primary school. Numeracy in primary school $=2.162+0.749$ numeracy in secondary school. 
Table A5: First stage regression for IV results

Financial Literacy

Maths education in primary school

$0.539 * * *$

Log GDP p.c. (PPP)

(0.173)

$9.982 * * *$

Population between ages 1564

$-1.248 * * *$

(0.204)

Secondary education

$-0.0136$

$(0.084)$

Tertiary education

0.043

$(0.101)$

Private credit to GDP

$-0.001$

$(0.028)$

Bank branches per 1000 km²

$-0.025$

$(0.030)$

Strength of legal rights index

$0.796 *$

$(0.404)$

Ease of doing business index

$-0.006$

(0.041)

Constant

0.530

(19.763)

Observations

93

F- test of first stage regression

15.24

F-test for weak instruments

9.67

Notes: This table reports the first stage regression of the IV regressions shown in this paper with robust standard errors in parentheses. The F-statistics reports the F-stat for the first stage regression. The F-test for weak instruments denotes passing the Stock-Yogo test at $15 \%$. ${ }^{* * *},{ }^{* *}$ and ${ }^{*}$ denote significance at the $1 \%, 5 \%$ and $10 \%$ levels, respectively. 
Table A6: Financial literacy and access to financial services - OLS and IV results

\begin{tabular}{|c|c|c|c|c|}
\hline & $\begin{array}{c}(1) \\
\text { Account } \\
\text { ownership } \\
\text { OLS }\end{array}$ & $\begin{array}{c}(2) \\
\text { Account } \\
\text { ownership } \\
\text { IV }\end{array}$ & $\begin{array}{c}\text { (3) } \\
\text { Debit card } \\
\text { ownership } \\
\text { OLS }\end{array}$ & $\begin{array}{c}\text { (4) } \\
\text { Debit card } \\
\text { ownership } \\
\text { IV }\end{array}$ \\
\hline Financial literacy & $\begin{array}{c}0.471^{* * *} \\
(0.158)\end{array}$ & $\begin{array}{c}1.885 * * * \\
(0.688)\end{array}$ & $\begin{array}{c}0.535^{* * *} \\
(0.184)\end{array}$ & $\begin{array}{c}1.636 * * * \\
(0.522)\end{array}$ \\
\hline Log GDP p.c. (PPP) & $\begin{array}{c}16.412 * * * \\
(3.183)\end{array}$ & $\begin{array}{c}2.686 \\
(8.298)\end{array}$ & $\begin{array}{c}16.925 * * * \\
(3.073)\end{array}$ & $\begin{array}{c}6.230 \\
(5.903)\end{array}$ \\
\hline $\begin{array}{l}\text { Population share } \\
\text { between } 15 \text { and } 64\end{array}$ & $\begin{array}{l}-0.701^{*} \\
(0.390)\end{array}$ & $\begin{array}{c}1.063 \\
(0.926)\end{array}$ & $\begin{array}{c}-0.754 * * \\
(0.365)\end{array}$ & $\begin{array}{c}0.621 \\
(0.719)\end{array}$ \\
\hline $\begin{array}{r}\text { Secondary } \\
\text { education }\end{array}$ & $\begin{array}{l}-0.046 \\
(0.135)\end{array}$ & $\begin{array}{l}-0.089 \\
(0.179)\end{array}$ & $\begin{array}{c}0.023 \\
(0.136)\end{array}$ & $\begin{array}{l}-0.011 \\
(0.171)\end{array}$ \\
\hline $\begin{array}{l}\text { Tertiary } \\
\text { education }\end{array}$ & $\begin{array}{l}-0.201 \\
(0.152)\end{array}$ & $\begin{array}{c}-0.364 * \\
(0.188)\end{array}$ & $\begin{array}{l}-0.106 \\
(0.177)\end{array}$ & $\begin{array}{l}-0.233 \\
(0.185)\end{array}$ \\
\hline $\begin{array}{l}\text { Private credit to } \\
\text { GDP }\end{array}$ & $\begin{array}{c}0.140 * * * \\
(0.031)\end{array}$ & $\begin{array}{l}0.119 * * \\
(0.049)\end{array}$ & $\begin{array}{l}0.092 * * \\
(0.045)\end{array}$ & $\begin{array}{l}0.076^{*} \\
(0.044)\end{array}$ \\
\hline $\begin{array}{l}\text { Bank branches per } \\
1000 \mathrm{~km}^{2}\end{array}$ & $\begin{array}{c}0.055 \\
(0.043)\end{array}$ & $\begin{array}{c}0.064 \\
(0.061)\end{array}$ & $\begin{array}{c}0.023 \\
(0.047)\end{array}$ & $\begin{array}{c}0.030 \\
(0.057)\end{array}$ \\
\hline $\begin{array}{l}\text { Strength of legal } \\
\text { rights index }\end{array}$ & $\begin{array}{c}0.175 \\
(0.625)\end{array}$ & $\begin{array}{l}-1.078 \\
(1.028)\end{array}$ & $\begin{array}{l}-0.187 \\
(0.640)\end{array}$ & $\begin{array}{l}-1.162 \\
(0.818)\end{array}$ \\
\hline $\begin{array}{l}\text { Ease of doing } \\
\text { business index }\end{array}$ & $\begin{array}{l}-0.097^{*} \\
(0.055)\end{array}$ & $\begin{array}{l}-0.048 \\
(0.096)\end{array}$ & $\begin{array}{l}-0.102^{*} \\
(0.061)\end{array}$ & $\begin{array}{l}-0.064 \\
(0.089)\end{array}$ \\
\hline Constant & $\begin{array}{c}-67.524 * * \\
(28.475)\end{array}$ & $\begin{array}{c}-96.144 * * \\
(42.738)\end{array}$ & $\begin{array}{c}-85.607 * * * \\
(27.491)\end{array}$ & $\begin{array}{c}-107.907 * * * \\
(39.002)\end{array}$ \\
\hline $\mathrm{R}^{2}$ & 0.82 & 0.64 & 0.81 & 0.70 \\
\hline Observations & 93 & 93 & 93 & 93 \\
\hline
\end{tabular}

Notes: The table reports OLS and IV regression results with robust standard errors in parentheses. Columns (1) and (2) show results for the proportion of people that have a bank account. Column (4) and (5) show results for the proportion that has a debit card as the outcome variable. Numeracy in primary schools acts as an instrument in these regressions. ${ }^{* * *},{ }^{* *}$ and $*$ denote significance at the $1 \%, 5 \%$ and $10 \%$ levels, respectively. 
Table A7: Financial literacy and use of financial services - OLS and IV results

\begin{tabular}{ccccc}
\hline & $\begin{array}{c}(1) \\
\text { Saved at } \\
\text { formal fin. } \\
\text { institution }\end{array}$ & $\begin{array}{c}\text { Saved at } \\
\text { formal fin. } \\
\text { institution }\end{array}$ & $\begin{array}{c}\text { Used debit } \\
\text { card in the } \\
\text { last year }\end{array}$ & $\begin{array}{c}\text { Used debit } \\
\text { card in the } \\
\text { last year }\end{array}$ \\
& $0.537^{* * *}$ & $1.117^{* * *}$ & $0.747^{* * *}$ & $1.630^{* * *}$ \\
\hline Financial literacy & $(0.108)$ & $(0.410)$ & $(0.183)$ & $(0.505)$ \\
& $7.020^{* * *}$ & 1.388 & $14.092^{* * *}$ & 5.520 \\
Log GDP p.c. (PPP) & $(2.129)$ & $(4.773)$ & $(2.913)$ & $(5.096)$ \\
& $-0.838^{* * *}$ & -0.114 & $-0.776^{* *}$ & 0.326 \\
Population share & $(0.303)$ & $(0.601)$ & $(0.356)$ & $(0.739)$ \\
between 15 and 64 & -0.024 & -0.042 & 0.008 & -0.019 \\
Secondary & $(0.109)$ & $(0.127)$ & $(0.127)$ & $(0.151)$ \\
education & 0.008 & -0.059 & 0.132 & 0.030 \\
Tertiary & $(0.134)$ & $(0.147)$ & $(0.170)$ & $(0.182)$ \\
education & $0.110^{* *}$ & $0.101^{* *}$ & 0.043 & 0.030 \\
Private credit to & $(0.046)$ & $(0.041)$ & $(0.043)$ & $(0.042)$ \\
GDP & $0.071^{*}$ & $0.075^{*}$ & 0.011 & 0.016 \\
Bank branches per & $(0.036)$ & $(0.040)$ & $(0.055)$ & $(0.058)$ \\
1000 km ${ }^{2}$ & 0.028 & -0.486 & 0.171 & -0.611 \\
Strength of legal & $(0.538)$ & $(0.735)$ & $(0.626)$ & $(0.799)$ \\
rights index & -0.031 & -0.011 & -0.069 & -0.038 \\
Ease of doing & $(0.048)$ & $(0.059)$ & $(0.069)$ & $(0.091)$ \\
business index & -13.922 & -25.666 & $-81.949 * *$ & $-99.822 * *$ \\
Constant & $(22.582)$ & $(27.199)$ & $(33.905)$ & $(43.958)$ \\
\hline R $^{2}$ & 0.75 & 0.68 & 0.77 & 0.70 \\
Observations & 93 & 93 & 93 & 93 \\
\hline
\end{tabular}

Notes: The table reports OLS and IV regression results with robust standard errors in brackets. Columns (1) and (2) show results for the proportion of people that have a bank account. Column (4) and (5) show results for the proportion that has a debit card as the outcome variable. Numeracy in primary schools acts as an instrument in these regressions. ${ }^{* * *},{ }^{* *}$ and $*$ denote significance at the $1 \%, 5 \%$ and $10 \%$ levels, respectively. 
Financial Literacy

Literacy education in primary school

0.2042

$(0.232)$

Log GDP p.c. (PPP)

$10.453^{* * *}$

(2.498)

Population between ages 1564

$-1.407 * * *$

(0.249)

Secondary education

$-0.016$

$(0.102)$

Tertiary education

0.050

$(0.113)$

Private credit to GDP

$(0.026)$

Bank branches per 1000 km²

$-0.001$

$(0.003)$

Strength of legal rights index

0.791

$(0.523)$

Ease of doing business index

$(0.052)$

Constant

22.074

24.93

\section{Observations}

77

F- test of first stage regression

9.78

F-test for weak instruments

0.77

Notes: This table reports the first stage regression of the IV regressions using literacy instead of numeracy as an instrument with robust standard errors in parentheses. The F-statistics reports the F-stat for the first stage regression. The F-test for weak instruments denotes not passing the Stock-Yogo test. ***, ** and * denote significance at the $1 \%, 5 \%$ and $10 \%$ levels, respectively. 
Table A9: Financial literacy and financial inclusion: Using literacy as an instrument

$(1)$

Account

ownership
(2)

Debit card

ownership
(3)

Saved at formal fin. $\quad$ card in the institution last year

\begin{tabular}{lcccc} 
& IV & IV & IV & IV \\
\hline Financial Literacy & 1.188 & 1.344 & 0.518 & 1.907 \\
& $(1.694)$ & $(1.830)$ & $(0.925)$ & $(1.939)$ \\
Log GDP p.c. (PPP) & 6.975 & 6.595 & 7.465 & 0.396 \\
& $(19.023)$ & $(20.250)$ & $(10.475)$ & $(21.242)$ \\
Population ages 15-64 & 0.048 & 0.125 & -1.024 & 0.669 \\
& $(2.466)$ & $(2.583)$ & $(1.323)$ & $(2.746)$ \\
Secondary education & -0.074 & -0.026 & 0.011 & -0.059 \\
& $(0.167)$ & $(0.182)$ & $(0.108)$ & $(0.190)$ \\
Tertiary education & -0.143 & -0.145 & 0.144 & 0.062 \\
& $(0.205)$ & $(0.240)$ & $(0.147)$ & $(0.249)$ \\
Private credit to GDP & $0.139 * * *$ & $0.095 * *$ & $0.101 * *$ & 0.052 \\
& $(0.038)$ & $(0.046)$ & $(0.046)$ & $(0.046)$ \\
Bank branches & -0.003 & -0.006 & 0.003 & -0.005 \\
per 1000 km ${ }^{2}$ & $(0.005)$ & $(0.005)$ & $(0.005)$ & $(0.006)$ \\
Strength of legal rights & -1.051 & -1.059 & -0.163 & -0.828 \\
index & $(1.528)$ & $(1.611)$ & $(0.968)$ & $(1.710)$ \\
Ease of doing business & -0.131 & -0.142 & -0.042 & -0.093 \\
index & $(0.120)$ & $(0.125)$ & $(0.075)$ & $(0.137)$ \\
Constant & -44.600 & -65.545 & -6.455 & -79.588 \\
& $(57.320)$ & $(57.664)$ & $(34.067)$ & $(65.509)$ \\
\hline $\mathrm{R}^{2}$ & 0.78 & 0.76 & 0.76 & 0.68 \\
Observations & 77 & 77 & 77 & 77 \\
\hline N & & &
\end{tabular}

Notes: The table reports IV regression results with robust standard errors in parentheses. ${ }^{* * *}$, ** and $*$ denote significance at the $1 \%, 5 \%$ and $10 \%$ levels, respectively. The imputed literacy rate in primary school is used as an instrument for financial literacy. 
Table A10: Financial literacy and borrowing decisions - OLS and IV results

\begin{tabular}{|c|c|c|c|c|c|c|}
\hline & $\begin{array}{c}\text { (1) } \\
\text { Borrowed } \\
\text { from a } \\
\text { formal fin. } \\
\text { institution } \\
\text { OLS }\end{array}$ & $\begin{array}{l}\text { (2) } \\
\text { Borrowed } \\
\text { from a } \\
\text { formal fin. } \\
\text { institution } \\
\text { IV }\end{array}$ & $\begin{array}{c}\text { (3) } \\
\text { Borrowed } \\
\text { from an } \\
\text { informal } \\
\text { institution } \\
\text { OLS }\end{array}$ & $\begin{array}{c}\text { (4) } \\
\text { Borrowed } \\
\text { from an } \\
\text { informal } \\
\text { institution } \\
\text { IV }\end{array}$ & $\begin{array}{l}\text { (5) } \\
\text { Credit card } \\
\text { used in the } \\
\text { last year } \\
\text { OLS }\end{array}$ & $\begin{array}{c}\text { (6) } \\
\text { Credit card } \\
\text { used in the } \\
\text { last year } \\
\text { IV }\end{array}$ \\
\hline Financial literacy & $\begin{array}{c}0.092 \\
(0.064)\end{array}$ & $\begin{array}{l}-0.085 \\
(0.150)\end{array}$ & $\begin{array}{c}-0.094 * * \\
(0.045)\end{array}$ & $\begin{array}{l}-0.597 * * \\
(0.248)\end{array}$ & $\begin{array}{l}0.264 * * \\
(0.111)\end{array}$ & $\begin{array}{l}0.856^{* *} \\
(0.351)\end{array}$ \\
\hline Log GDP p.c. (PPP) & $\begin{array}{c}0.360 \\
(0.972)\end{array}$ & $\begin{array}{c}1.872 \\
(1.937)\end{array}$ & $\begin{array}{c}0.650 \\
(1.093)\end{array}$ & $\begin{array}{l}5.654^{*} \\
(2.926)\end{array}$ & $\begin{array}{c}7.655^{* * * *} \\
(1.688)\end{array}$ & $\begin{array}{c}3.102 \\
(4.214)\end{array}$ \\
\hline $\begin{array}{c}\text { Population share } \\
\text { between } 15-64\end{array}$ & $\begin{array}{c}0.179 \\
(0.131)\end{array}$ & $\begin{array}{l}-0.177 \\
(0.248)\end{array}$ & $\begin{array}{c}0.008 \\
(0.100)\end{array}$ & $\begin{array}{l}-0.666^{*} \\
(0.337)\end{array}$ & $\begin{array}{c}-0.593^{* * * *} \\
(0.177)\end{array}$ & $\begin{array}{c}0.056 \\
(0.508)\end{array}$ \\
\hline $\begin{array}{l}\text { Secondary } \\
\text { education }\end{array}$ & $\begin{array}{c}0.032 \\
(0.047)\end{array}$ & $\begin{array}{c}0.069 \\
(0.051)\end{array}$ & $\begin{array}{l}-0.051 \\
(0.044)\end{array}$ & $\begin{array}{l}-0.023 \\
(0.083)\end{array}$ & $\begin{array}{l}-0.031 \\
(0.056)\end{array}$ & $\begin{array}{l}-0.023 \\
(0.096)\end{array}$ \\
\hline $\begin{array}{l}\text { Tertiary } \\
\text { education }\end{array}$ & $\begin{array}{c}0.022 \\
(0.050)\end{array}$ & $\begin{array}{c}0.086 \\
(0.063)\end{array}$ & $\begin{array}{c}0.011 \\
(0.038)\end{array}$ & $\begin{array}{c}0.071 \\
(0.069)\end{array}$ & $\begin{array}{l}0.240 * * \\
(0.100)\end{array}$ & $\begin{array}{c}0.123 \\
(0.149)\end{array}$ \\
\hline $\begin{array}{l}\text { Private credit } \\
\text { to GDP }\end{array}$ & $\begin{array}{c}0.003 \\
(0.016)\end{array}$ & $\begin{array}{l}-0.003 \\
(0.018)\end{array}$ & $\begin{array}{l}-0.007 \\
(0.016)\end{array}$ & $\begin{array}{l}-0.001 \\
(0.026)\end{array}$ & $\begin{array}{l}0.059 * \\
(0.032)\end{array}$ & $\begin{array}{c}0.039 \\
(0.036)\end{array}$ \\
\hline $\begin{array}{r}\text { Bank branches } \\
\text { per } 1000 \mathrm{~km}^{2}\end{array}$ & $\begin{array}{l}-0.009 \\
(0.006)\end{array}$ & $\begin{array}{l}-0.001 \\
(0.021)\end{array}$ & $\begin{array}{l}-0.011^{*} \\
(0.006)\end{array}$ & $\begin{array}{l}-0.027 \\
(0.021)\end{array}$ & $\begin{array}{l}0.037^{*} \\
(0.019)\end{array}$ & $\begin{array}{c}0.076 \\
(0.052)\end{array}$ \\
\hline $\begin{array}{l}\text { Strength of legal } \\
\text { rights index }\end{array}$ & $\begin{array}{c}0.273 \\
(0.270)\end{array}$ & $\begin{array}{c}0.195 \\
(0.295)\end{array}$ & $\begin{array}{l}-0.047 \\
(0.185)\end{array}$ & $\begin{array}{c}0.301 \\
(0.338)\end{array}$ & $\begin{array}{c}0.405 \\
(0.323)\end{array}$ & $\begin{array}{l}-0.168 \\
(0.610)\end{array}$ \\
\hline $\begin{array}{l}\text { Ease of doing } \\
\text { business index }\end{array}$ & $\begin{array}{c}-0.039 * * \\
(0.019)\end{array}$ & $\begin{array}{c}-0.052 * * \\
(0.024)\end{array}$ & $\begin{array}{c}0.014 \\
(0.017)\end{array}$ & $\begin{array}{l}-0.011 \\
(0.032)\end{array}$ & $\begin{array}{l}-0.017 \\
(0.033)\end{array}$ & $\begin{array}{c}0.008 \\
(0.046)\end{array}$ \\
\hline Constant & $\begin{array}{c}-5.791 \\
(10.457)\end{array}$ & $\begin{array}{c}8.101 \\
(12.622)\end{array}$ & $\begin{array}{c}3.033 \\
(9.766)\end{array}$ & $\begin{array}{c}15.769 \\
(16.756)\end{array}$ & $\begin{array}{l}-35.636 * \\
(18.617)\end{array}$ & $\begin{array}{c}-53.646^{* *} \\
(25.766)\end{array}$ \\
\hline$\overline{\mathrm{R}^{2}}$ & 0.44 & 0.38 & 0.18 & & 0.71 & 0.60 \\
\hline Observations & 119 & 93 & 119 & 93 & 119 & 93 \\
\hline
\end{tabular}




\begin{tabular}{|c|c|c|}
\hline & $\begin{array}{l}\text { (3) } \\
\text { High frequency of } \\
\text { account use } \\
\text { OLS }\end{array}$ & $\begin{array}{l}\text { (4) } \\
\text { High frequency of } \\
\text { account use } \\
\text { IV }\end{array}$ \\
\hline \multirow[t]{2}{*}{ Financial literacy } & $0.588^{* * *}$ & $1.471^{* * *}$ \\
\hline & {$[0.115]$} & {$[0.445]$} \\
\hline \multirow[t]{2}{*}{ Log GDP p.c. (PPP) } & $8.835^{* * *}$ & 2.071 \\
\hline & [1.805] & [4.641] \\
\hline \multirow{2}{*}{$\begin{array}{c}\text { Population share } \\
\text { between 15-64 }\end{array}$} & $-1.119^{* * *}$ & -0.240 \\
\hline & {$[0.252]$} & {$[0.643]$} \\
\hline \multirow{2}{*}{$\begin{array}{r}\text { Secondary } \\
\text { education }\end{array}$} & -0.058 & -0.023 \\
\hline & [0.073] & [0.123] \\
\hline \multirow{2}{*}{$\begin{array}{l}\text { Tertiary } \\
\text { education }\end{array}$} & $0.314^{* *}$ & 0.151 \\
\hline & [0.113] & {$[0.157]$} \\
\hline \multirow{2}{*}{$\begin{array}{l}\text { Private credit to } \\
\text { GDP }\end{array}$} & $0.105^{* *}$ & $0.086^{*}$ \\
\hline & [0.032] & {$[0.036]$} \\
\hline \multirow{2}{*}{$\begin{array}{l}\text { Bank branches } \\
\text { per } 1000 \text { km² }^{2}\end{array}$} & 0.021 & 0.038 \\
\hline & [0.015] & {$[0.050]$} \\
\hline \multirow{2}{*}{$\begin{array}{l}\text { Strength of legal } \\
\text { rights index }\end{array}$} & 0.285 & -0.703 \\
\hline & [0.463] & [0.738] \\
\hline \multirow{2}{*}{$\begin{array}{l}\text { Ease of doing } \\
\text { business index }\end{array}$} & -0.079 & -0.052 \\
\hline & {$[0.043]$} & [0.069] \\
\hline \multirow[t]{2}{*}{ Constant } & -15.432 & -37.482 \\
\hline & [22.296] & [33.796] \\
\hline $\mathrm{R}^{2}$ & 0.82 & 0.73 \\
\hline Observations & 119 & 93 \\
\hline \multicolumn{3}{|c|}{$\begin{array}{l}\text { Notes: The table reports OLS regression in column (1), and IV regression results in column (2) with } \\
\text { robust standard errors in parentheses. } * * *, * * \text { and } * \text { denote significance at the } 1 \%, 5 \% \text { and } 10 \% \text { levels } \\
\text { respectively. High frequency of account use denotes the percentage of the population (older than } 1 \\
\text { years) that have taken money out of a formal bank account at a bank or other formal financia } \\
\text { institution at least three times in a typical month, including cash withdrawals, electronic payments o } \\
\text { purchases, checks, or any other type of payment debit, either by account owner or other parties. }\end{array}$} \\
\hline
\end{tabular}


Table A12: Financial literacy and account ownership - additional control variables

\begin{tabular}{|c|c|c|c|c|}
\hline & $\begin{array}{c}(1) \\
\text { Account } \\
\text { ownership } \\
\text { OLS }\end{array}$ & $\begin{array}{c}\text { (2) } \\
\text { Account } \\
\text { ownership } \\
\text { OLS }\end{array}$ & $\begin{array}{c}\text { (3) } \\
\text { Account } \\
\text { ownership } \\
\text { OLS }\end{array}$ & $\begin{array}{c}\text { (4) } \\
\text { Account } \\
\text { ownership } \\
\text { OLS }\end{array}$ \\
\hline Financial literacy & $\begin{array}{c}0.580 * * * \\
(0.174)\end{array}$ & $\begin{array}{c}0.599 * * * \\
(0.177)\end{array}$ & $\begin{array}{c}0.537 * * * \\
(0.188)\end{array}$ & $\begin{array}{l}0.508^{*} \\
(0.254)\end{array}$ \\
\hline Log GDP p.c. (PPP) & $\begin{array}{c}12.106 * * * \\
(3.627)\end{array}$ & $\begin{array}{c}12.409 * * * \\
(3.679)\end{array}$ & $\begin{array}{l}19.127^{* * * *} \\
(3.444)\end{array}$ & $\begin{array}{c}19.828 * * * \\
(4.189)\end{array}$ \\
\hline $\begin{array}{c}\text { Population share } \\
\text { between } 15-64\end{array}$ & $\begin{array}{l}-0.109 \\
(0.380)\end{array}$ & $\begin{array}{l}-0.091 \\
(0.386)\end{array}$ & $\begin{array}{l}-0.167 \\
(0.431)\end{array}$ & $\begin{array}{l}-0.693 \\
(0.590)\end{array}$ \\
\hline Secondary education & $\begin{array}{c}0.004 \\
(0.133)\end{array}$ & $\begin{array}{c}0.006 \\
(0.132)\end{array}$ & $\begin{array}{l}-0.045 \\
(0.152)\end{array}$ & $\begin{array}{l}-0.053 \\
(0.181)\end{array}$ \\
\hline Tertiary education & $\begin{array}{l}-0.142 \\
(0.164)\end{array}$ & $\begin{array}{l}-0.157 \\
(0.166)\end{array}$ & $\begin{array}{l}-0.244 \\
(0.184)\end{array}$ & $\begin{array}{l}-0.415 \\
(0.302)\end{array}$ \\
\hline Private credit to GDP & $\begin{array}{c}0.122 * * * \\
(0.032)\end{array}$ & $\begin{array}{c}0.121^{* * *} \\
(0.032)\end{array}$ & $\begin{array}{c}0.111^{* * *} \\
(0.031)\end{array}$ & $\begin{array}{l}0.147^{* *} \\
(0.057)\end{array}$ \\
\hline Bank branches per 1000 km² & $\begin{array}{c}0.052 * * * \\
(0.019)\end{array}$ & $\begin{array}{c}0.025 \\
(0.021)\end{array}$ & $\begin{array}{c}0.023 \\
(0.023)\end{array}$ & $\begin{array}{c}0.027 \\
(0.025)\end{array}$ \\
\hline Strength of legal rights index & $\begin{array}{c}0.320 \\
(0.692)\end{array}$ & $\begin{array}{c}0.530 \\
(0.712)\end{array}$ & $\begin{array}{c}0.682 \\
(0.720)\end{array}$ & $\begin{array}{c}0.867 \\
(1.021)\end{array}$ \\
\hline Ease of doing business index & $\begin{array}{l}-0.070 \\
(0.064)\end{array}$ & $\begin{array}{l}-0.050 \\
(0.068)\end{array}$ & $\begin{array}{l}-0.024 \\
(0.068)\end{array}$ & $\begin{array}{c}0.023 \\
(0.092)\end{array}$ \\
\hline Political risk & $\begin{array}{c}0.176 \\
(0.283)\end{array}$ & $\begin{array}{c}0.188 \\
(0.282)\end{array}$ & $\begin{array}{l}-0.001 \\
(0.308)\end{array}$ & $\begin{array}{c}0.069 \\
(0.443)\end{array}$ \\
\hline ATMs per $1000 \mathrm{~km}^{2}$ & & $\begin{array}{c}0.016 * * * \\
(0.006)\end{array}$ & $\begin{array}{c}0.018 * * * \\
(0.007)\end{array}$ & $\begin{array}{c}0.023 * * * \\
(0.007)\end{array}$ \\
\hline $\begin{array}{l}\text { Cost checking account } \\
\text { (imputed) }\end{array}$ & & & $\begin{array}{l}0.957 * * \\
(0.473)\end{array}$ & \\
\hline $\begin{array}{l}\text { Cost checking account } \\
\text { (original) }\end{array}$ & & & & $\begin{array}{c}0.490 \\
(1.576)\end{array}$ \\
\hline Constant & $\begin{array}{c}-84.884 * * \\
(32.868) \\
\end{array}$ & $\begin{array}{c}-93.177 * * * \\
(33.779) \\
\end{array}$ & $\begin{array}{c}-136.445 * * * \\
(38.592) \\
\end{array}$ & $\begin{array}{c}-116.704^{* *} \\
(55.511)\end{array}$ \\
\hline $\mathrm{R}^{2}$ & 0.79 & 0.79 & 0.78 & 0.77 \\
\hline Observations & 103 & 101 & 88 & 57 \\
\hline
\end{tabular}


Table A13: Financial literacy and use of financial services - OLS results including country group dummies

\begin{tabular}{|c|c|c|c|c|}
\hline & $\begin{array}{c}(1) \\
\text { Account } \\
\text { ownserhip } \\
\text { OLS }\end{array}$ & $\begin{array}{c}(2) \\
\text { Debit card } \\
\text { ownership } \\
\text { OLS }\end{array}$ & $\begin{array}{c}\text { (3) } \\
\text { Saved at } \\
\text { formal fin. } \\
\text { institution } \\
\text { OLS }\end{array}$ & $\begin{array}{c}\text { (4) } \\
\text { Used debit } \\
\text { card in the last } \\
\text { year } \\
\text { OLS }\end{array}$ \\
\hline Financial literacy & $\begin{array}{l}0.411^{* *} \\
(0.145)\end{array}$ & $\begin{array}{c}0.349^{*} \\
(0.153)\end{array}$ & $\begin{array}{l}0.523^{* * *} \\
(0.100)\end{array}$ & $\begin{array}{l}0.472^{* *} \\
(0.147)\end{array}$ \\
\hline Log GDP p.c. (PPP) & $\begin{array}{c}6.846 \\
(4.758)\end{array}$ & $\begin{array}{l}7.264^{*} \\
(3.176)\end{array}$ & $\begin{array}{l}7.840^{* *} \\
(2.904)\end{array}$ & $\begin{array}{l}6.197^{*} \\
(2.644)\end{array}$ \\
\hline $\begin{array}{c}\text { Population share } \\
\text { between } 15-64\end{array}$ & $\begin{array}{l}-0.055 \\
(0.317)\end{array}$ & $\begin{array}{l}-0.196 \\
(0.271)\end{array}$ & $\begin{array}{l}-0.618^{* *} \\
(0.220)\end{array}$ & $\begin{array}{l}-0.370 \\
(0.253)\end{array}$ \\
\hline $\begin{array}{r}\text { Secondary } \\
\text { education }\end{array}$ & $\begin{array}{c}0.021 \\
(0.112)\end{array}$ & $\begin{array}{c}0.049 \\
(0.098)\end{array}$ & $\begin{array}{l}-0.062 \\
(0.077)\end{array}$ & $\begin{array}{l}-0.006 \\
(0.081)\end{array}$ \\
\hline $\begin{array}{l}\text { Tertiary } \\
\text { education }\end{array}$ & $\begin{array}{l}-0.130 \\
(0.149)\end{array}$ & $\begin{array}{c}0.013 \\
(0.148)\end{array}$ & $\begin{array}{c}-0.022 \\
(0.115)\end{array}$ & $\begin{array}{c}0.169 \\
(0.137)\end{array}$ \\
\hline $\begin{array}{l}\text { Private credit to } \\
\text { GDP }\end{array}$ & $\begin{array}{c}0.122^{* * *} \\
(0.031)\end{array}$ & $\begin{array}{c}0.079 \\
(0.050)\end{array}$ & $\begin{array}{c}0.112^{*} \\
(0.044)\end{array}$ & $\begin{array}{c}0.027 \\
(0.046)\end{array}$ \\
\hline $\begin{array}{r}\text { Bank branches } \\
\text { per } 1000 \mathrm{~km}^{2}\end{array}$ & $\begin{array}{l}0.054^{* *} \\
(0.019)\end{array}$ & $\begin{array}{c}0.026 \\
(0.016)\end{array}$ & $\begin{array}{c}0.032 \\
(0.018)\end{array}$ & $\begin{array}{c}0.018 \\
(0.017)\end{array}$ \\
\hline $\begin{array}{l}\text { Strength of legal } \\
\text { rights index }\end{array}$ & $\begin{array}{c}0.412 \\
(0.538)\end{array}$ & $\begin{array}{c}0.100 \\
(0.456)\end{array}$ & $\begin{array}{c}0.113 \\
(0.413)\end{array}$ & $\begin{array}{c}0.414 \\
(0.399)\end{array}$ \\
\hline $\begin{array}{l}\text { Ease of doing } \\
\text { business index }\end{array}$ & $\begin{array}{l}-0.093^{*} \\
(0.042)\end{array}$ & $\begin{array}{l}-0.096^{*} \\
(0.045)\end{array}$ & $\begin{array}{l}-0.038 \\
(0.041)\end{array}$ & $\begin{array}{l}-0.072 \\
(0.042)\end{array}$ \\
\hline Low income country & $\begin{array}{l}-20.595 \\
(13.810)\end{array}$ & $\begin{array}{l}-21.964^{*} \\
(9.184)\end{array}$ & $\begin{array}{c}3.387 \\
(9.160)\end{array}$ & $\begin{array}{r}-21.268^{*} \\
(9.681)\end{array}$ \\
\hline $\begin{array}{l}\text { Lower middle } \\
\text { income country }\end{array}$ & $\begin{array}{l}-19.580^{*} \\
(8.677)\end{array}$ & $\begin{array}{c}-23.710^{* * *} \\
(6.075)\end{array}$ & $\begin{array}{c}3.949 \\
(6.238)\end{array}$ & $\begin{array}{c}-24.098^{* * *} \\
(6.671)\end{array}$ \\
\hline $\begin{array}{l}\text { Upper middle } \\
\text { income country }\end{array}$ & $\begin{array}{l}-11.375^{*} \\
(4.857)\end{array}$ & $\begin{array}{c}-16.777^{* * *} \\
(4.611)\end{array}$ & $\begin{array}{l}-0.811 \\
(4.075)\end{array}$ & $\begin{array}{c}-20.828^{* * *} \\
(5.014)\end{array}$ \\
\hline Constant & $\begin{array}{l}-10.981 \\
(48.494)\end{array}$ & $\begin{array}{l}-14.810 \\
(30.251)\end{array}$ & $\begin{array}{l}-32.491 \\
(30.116)\end{array}$ & $\begin{array}{c}-8.987 \\
(30.689)\end{array}$ \\
\hline$\overline{\mathrm{R}^{2}}$ & 0.82 & 0.84 & 0.74 & 0.83 \\
\hline Observations & 119 & 119 & 119 & 119 \\
\hline
\end{tabular}

Notes: The table reports OLS regression results. Robust standard errors are shown in parentheses. The omitted country group variable is high income country. ${ }^{* * *}, * *$ and $*$ denote significance at the $1 \%, 5 \%$ and $10 \%$ levels, respectively. 
Table A14: Financial literacy and access to financial services - OLS results - without population and/or education variables

\begin{tabular}{ccccc}
\hline & $\begin{array}{c}(1) \\
\text { Account } \\
\text { ownership } \\
\text { OLS }\end{array}$ & $\begin{array}{c}\text { Account } \\
\text { ownership } \\
\text { OLS }\end{array}$ & $\begin{array}{c}(3) \\
\text { Debit card } \\
\text { ownership } \\
\text { OLS }\end{array}$ & $\begin{array}{c}(4) \\
\text { Debit card } \\
\text { ownership } \\
\text { OLS }\end{array}$ \\
\hline Financial literacy & $0.535^{* * *}$ & $0.464^{* * *}$ & $0.604^{* * *}$ & $0.495^{* *}$ \\
& $(0.108)$ & $(0.135)$ & $(0.138)$ & $(0.153)$ \\
Log GDP p.c. (PPP) & $11.533^{* * *}$ & $13.295^{* * *}$ & $12.499^{* * *}$ & $14.845^{* * *}$ \\
& $(2.285)$ & $(2.788)$ & $(2.192)$ & $(2.674)$ \\
Population share & & -0.141 & & -0.362 \\
between 15-64 & & $(0.347)$ & & $(0.311)$ \\
Secondary & 0.045 & & 0.027 & \\
education & $(0.099)$ & & $(0.103)$ & $0.092^{*}$ \\
Private credit to & $0.129^{* * *}$ & $0.128^{* * *}$ & $0.092^{*}$ & $(0.044)$ \\
GDP & $(0.030)$ & $(0.031)$ & $(0.044)$ & 0.030 \\
Bank branches & $0.057^{* *}$ & $0.052^{* *}$ & $0.035^{*}$ & $(0.018)$ \\
per 1000 km & $(0.017)$ & $(0.017)$ & $(0.017)$ & -0.015 \\
Strength of legal & 0.334 & 0.289 & 0.055 & $(0.513)$ \\
rights index & $(0.543)$ & $(0.538)$ & $(0.532)$ & -0.089 \\
Ease of doing & -0.079 & -0.078 & -0.079 & $(0.051)$ \\
business index & $(0.051)$ & $(0.052)$ & $(0.052)$ & $-91.438^{* * *}$ \\
Constant & $-77.990^{* *}$ & $-79.807^{* *}$ & $-99.678^{* * *}$ & $(26.288)$ \\
\hline R & $(24.572)$ & $(27.092)$ & $(24.437)$ & 0.80 \\
Observations & 0.80 & 0.78 & 0.81 & 120 \\
\hline Notes: The table reports OLS regression results. Robust standard errors are shown in parentheses. Columns (1) and
\end{tabular}

Notes: The table reports OLS regression results. Robust standard errors are shown in parentheses. Columns (1) and (2) show results with the proportion of the population that have a bank account as the outcome variable. Columns (3) and (4) show results with the proportion that has a debit card as the outcome variable. ${ }^{* * *}$, ** and * denote significance at the $1 \%, 5 \%$ and $10 \%$ levels, respectively. 
Table A15: Financial literacy and use of financial services - OLS results - without population and/or education

\begin{tabular}{|c|c|c|c|c|}
\hline & $\begin{array}{c}\text { (1) } \\
\text { Saved at formal } \\
\text { fin. institution } \\
\text { OLS }\end{array}$ & $\begin{array}{c}(2) \\
\text { Saved at formal } \\
\text { fin. institution } \\
\text { OLS }\end{array}$ & $\begin{array}{c}\text { (3) } \\
\text { Used debit card } \\
\text { in the last year } \\
\text { OLS }\end{array}$ & $\begin{array}{c}\text { (4) } \\
\text { Used debit card } \\
\text { in the last year } \\
\text { OLS }\end{array}$ \\
\hline Financial literacy & $\begin{array}{l}0.652^{* * *} \\
(0.080)\end{array}$ & $\begin{array}{l}0.522^{* * *} \\
(0.084)\end{array}$ & $\begin{array}{l}0.844^{* * *} \\
(0.150)\end{array}$ & $\begin{array}{l}0.689^{* * *} \\
(0.157)\end{array}$ \\
\hline Log GDP p.c. (PPP) & $\begin{array}{l}4.278^{* *} \\
(1.368)\end{array}$ & $\begin{array}{l}6.157^{* * *} \\
(1.516)\end{array}$ & $\begin{array}{l}11.183^{* * *} \\
(2.302)\end{array}$ & $\begin{array}{c}13.585^{* * *} \\
(2.531)\end{array}$ \\
\hline $\begin{array}{c}\text { Population share } \\
\text { between } 15-64\end{array}$ & & $\begin{array}{l}-0.575^{* *} \\
(0.213)\end{array}$ & & $\begin{array}{l}-0.572 \\
(0.320)\end{array}$ \\
\hline $\begin{array}{r}\text { Secondary } \\
\text { education }\end{array}$ & $\begin{array}{l}-0.053 \\
(0.066)\end{array}$ & & $\begin{array}{l}-0.066 \\
(0.102)\end{array}$ & \\
\hline $\begin{array}{l}\text { Private credit to } \\
\text { GDP }\end{array}$ & $\begin{array}{l}0.113^{*} \\
(0.045)\end{array}$ & $\begin{array}{l}0.118^{* *} \\
(0.045)\end{array}$ & $\begin{array}{c}0.045 \\
(0.040)\end{array}$ & $\begin{array}{c}0.052 \\
(0.040)\end{array}$ \\
\hline $\begin{array}{r}\text { Bank branches } \\
\text { per } 1000 \mathrm{~km}^{2}\end{array}$ & $\begin{array}{c}0.033 \\
(0.019)\end{array}$ & $\begin{array}{c}0.032 \\
(0.019)\end{array}$ & $\begin{array}{c}0.033 \\
(0.019)\end{array}$ & $\begin{array}{c}0.028 \\
(0.020)\end{array}$ \\
\hline $\begin{array}{l}\text { Strength of legal } \\
\text { rights index }\end{array}$ & $\begin{array}{c}0.183 \\
(0.430)\end{array}$ & $\begin{array}{c}0.137 \\
(0.415)\end{array}$ & $\begin{array}{c}0.404 \\
(0.543)\end{array}$ & $\begin{array}{c}0.320 \\
(0.521)\end{array}$ \\
\hline $\begin{array}{l}\text { Ease of doing } \\
\text { business index }\end{array}$ & $\begin{array}{c}0.005 \\
(0.037)\end{array}$ & $\begin{array}{l}-0.022 \\
(0.036)\end{array}$ & $\begin{array}{l}-0.048 \\
(0.054)\end{array}$ & $\begin{array}{l}-0.065 \\
(0.055)\end{array}$ \\
\hline Constant & $\begin{array}{l}-47.266^{* *} \\
(16.310)\end{array}$ & $\begin{array}{l}-23.646 \\
(18.314)\end{array}$ & $\begin{array}{c}-104.878^{* * *} \\
(26.050)\end{array}$ & $\begin{array}{l}-86.662^{* *} \\
(30.726)\end{array}$ \\
\hline $\mathrm{R}^{2}$ & 0.72 & 0.73 & 0.76 & 0.76 \\
\hline Observations & 120 & 120 & 120 & 120 \\
\hline
\end{tabular}

Notes: The table reports OLS regression results. Robust standard errors are shown in parentheses. The outcome variables are the proportion of people that saved at a formal financial institution and the proportion of people that used their debit card during the last year. ${ }^{* * *},{ }^{* *}$ and ${ }^{*}$ denote significance at the $1 \%, 5 \%$ and $10 \%$ levels, respectively. 
Table A16: Financial literacy and financial inclusion incl. religiosity - OLS results

\begin{tabular}{|c|c|c|c|c|}
\hline & $\begin{array}{c}(1) \\
\text { Account } \\
\text { ownership } \\
\text { OLS }\end{array}$ & $\begin{array}{c}(2) \\
\text { Debit card } \\
\text { ownership } \\
\text { OLS }\end{array}$ & $\begin{array}{l}\text { (3) } \\
\text { Saved at formal } \\
\text { fin. institution } \\
\text { OLS }\end{array}$ & $\begin{array}{c}\text { (4) } \\
\text { Used debit card } \\
\text { in the last year } \\
\text { OLS }\end{array}$ \\
\hline Financial literacy & $\begin{array}{l}0.364 * * \\
(0.159)\end{array}$ & $\begin{array}{c}0.443^{* * *} \\
(0.138)\end{array}$ & $\begin{array}{c}0.357 * * * \\
(0.083)\end{array}$ & $\begin{array}{c}0.627 * * * \\
(0.112)\end{array}$ \\
\hline Log GDP p.c. (PPP) & $\begin{array}{c}14.211^{* * * *} \\
(2.482)\end{array}$ & $\begin{array}{c}14.326 * * * \\
(2.212)\end{array}$ & $\begin{array}{c}5.009 * * * \\
(1.547)\end{array}$ & $\begin{array}{c}9.896 * * * \\
(2.074)\end{array}$ \\
\hline $\begin{array}{c}\text { Population share } \\
\text { between } 15-64\end{array}$ & $\begin{array}{l}-0.378 \\
(0.342)\end{array}$ & $\begin{array}{l}-0.511^{*} \\
(0.278)\end{array}$ & $\begin{array}{c}-0.523^{* *} \\
(0.219)\end{array}$ & $\begin{array}{c}-0.585^{* *} \\
(0.257)\end{array}$ \\
\hline $\begin{array}{r}\text { Secondary } \\
\text { education }\end{array}$ & $\begin{array}{c}0.106 \\
(0.102)\end{array}$ & $\begin{array}{c}0.089 \\
(0.104)\end{array}$ & $\begin{array}{c}0.087 \\
(0.068)\end{array}$ & $\begin{array}{c}0.002 \\
(0.101)\end{array}$ \\
\hline $\begin{array}{l}\text { Private credit to } \\
\text { GDP }\end{array}$ & $\begin{array}{l}-0.014 \\
(0.126)\end{array}$ & $\begin{array}{c}0.174 \\
(0.137)\end{array}$ & $\begin{array}{c}0.245^{* * *} \\
(0.083)\end{array}$ & $\begin{array}{c}0.393 * * * \\
(0.125)\end{array}$ \\
\hline $\begin{array}{r}\text { Bank branches } \\
\text { per } 1000 \mathrm{~km}^{2}\end{array}$ & $\begin{array}{c}0.105^{* * *} \\
(0.033)\end{array}$ & $\begin{array}{c}0.062 \\
(0.041)\end{array}$ & $\begin{array}{c}0.087 * * * \\
(0.030)\end{array}$ & $\begin{array}{c}0.059 \\
(0.036)\end{array}$ \\
\hline $\begin{array}{l}\text { Strength of legal } \\
\text { rights index }\end{array}$ & $\begin{array}{c}0.058^{* * *} \\
(0.017)\end{array}$ & $\begin{array}{c}0.044^{* * *} \\
(0.015)\end{array}$ & $\begin{array}{l}0.030 * \\
(0.016)\end{array}$ & $\begin{array}{c}0.030 * * \\
(0.015)\end{array}$ \\
\hline $\begin{array}{l}\text { Ease of doing } \\
\text { business index }\end{array}$ & $\begin{array}{l}-0.222 \\
(0.557)\end{array}$ & $\begin{array}{l}-0.361 \\
(0.519)\end{array}$ & $\begin{array}{c}0.027 \\
(0.395)\end{array}$ & $\begin{array}{l}0.080 \\
(0.546)\end{array}$ \\
\hline Financial literacy & $\begin{array}{l}-0.042 \\
(0.048)\end{array}$ & $\begin{array}{l}-0.059 \\
(0.050)\end{array}$ & $\begin{array}{c}-0.012 \\
(0.031)\end{array}$ & $\begin{array}{l}-0.032 \\
(0.056)\end{array}$ \\
\hline Christianity (prot.) & $\begin{array}{c}8.591 \\
(10.252)\end{array}$ & $\begin{array}{l}10.697 \\
(8.488)\end{array}$ & $\begin{array}{c}16.591 * * * \\
(5.744)\end{array}$ & $\begin{array}{l}7.553 \\
(9.124)\end{array}$ \\
\hline Christianity (other) & $\begin{array}{c}4.608 \\
(7.269)\end{array}$ & $\begin{array}{l}-1.242 \\
(6.123)\end{array}$ & $\begin{array}{c}-14.656 * * * \\
(3.958)\end{array}$ & $\begin{array}{c}-12.242 * \\
(6.667)\end{array}$ \\
\hline Judaism & $\begin{array}{c}6.551 \\
(7.135)\end{array}$ & $\begin{array}{c}-59.908 * * * \\
(5.759)\end{array}$ & $\begin{array}{l}9.820^{*} \\
(5.259)\end{array}$ & $\begin{array}{c}-69.786^{* * * *} \\
(5.025)\end{array}$ \\
\hline Islam (Sunni) & $\begin{array}{l}-4.810 \\
(5.051)\end{array}$ & $\begin{array}{l}-3.045 \\
(4.569)\end{array}$ & $\begin{array}{l}-2.666 \\
(3.232)\end{array}$ & $\begin{array}{l}-7.097 \\
(4.372)\end{array}$ \\
\hline Islam (Shi’a) & $\begin{array}{c}-34.167 * * * \\
(8.163)\end{array}$ & $\begin{array}{c}-27.957 * * * \\
(9.093)\end{array}$ & $\begin{array}{c}-12.842^{* *} \\
(5.188)\end{array}$ & $\begin{array}{c}-21.271 * * \\
(9.210)\end{array}$ \\
\hline Islam (other) & $\begin{array}{l}-11.189 \\
(35.004)\end{array}$ & $\begin{array}{l}-28.893 \\
(39.566)\end{array}$ & $\begin{array}{c}-3.205 \\
(49.855)\end{array}$ & $\begin{array}{c}-2.523 \\
(44.700)\end{array}$ \\
\hline Buddhism & $\begin{array}{c}13.780 \\
(11.516)\end{array}$ & $\begin{array}{c}1.445 \\
(8.419)\end{array}$ & $\begin{array}{c}12.148 * * \\
(5.566)\end{array}$ & $\begin{array}{c}-14.145 * * \\
(6.395)\end{array}$ \\
\hline Hinduism & $\begin{array}{c}26.042^{* * * *} \\
(7.234)\end{array}$ & $\begin{array}{l}11.507^{*} \\
(6.167)\end{array}$ & $\begin{array}{c}15.349 * * * \\
(4.911)\end{array}$ & $\begin{array}{l}5.002 \\
(5.308)\end{array}$ \\
\hline Non-religious & $\begin{array}{c}29.992^{* *} \\
(13.362)\end{array}$ & $\begin{array}{c}30.184^{* *} \\
(15.208)\end{array}$ & $\begin{array}{l}15.506 \\
(9.702)\end{array}$ & $\begin{array}{l}29.684^{*} \\
(15.399)\end{array}$ \\
\hline Other religions & $\begin{array}{c}-1.979 \\
(11.043)\end{array}$ & $\begin{array}{c}5.264 \\
(7.667)\end{array}$ & $\begin{array}{c}8.600 \\
(7.950)\end{array}$ & $\begin{array}{c}-19.735 * * * \\
(5.873)\end{array}$ \\
\hline Constant & $\begin{array}{c}-77.603 * * * \\
(26.730)\end{array}$ & $\begin{array}{c}-84.495^{* * * *} \\
(24.908)\end{array}$ & $\begin{array}{l}-18.750 \\
(17.365)\end{array}$ & $\begin{array}{c}-55.657 * * \\
(26.314)\end{array}$ \\
\hline $\mathrm{R}^{2}$ & 0.84 & 0.87 & 0.84 & 0.86 \\
\hline Observations & 117 & 117 & 117 & 117 \\
\hline
\end{tabular}


Table A17: Financial literacy and financial inclusion incl. Hofstede's cultural dimensions - OLS results

\begin{tabular}{|c|c|c|c|c|}
\hline & $\begin{array}{c}\text { (1) } \\
\text { Account } \\
\text { ownership } \\
\text { OLS }\end{array}$ & $\begin{array}{c}\quad(2) \\
\text { Debit card } \\
\text { ownership } \\
\quad \text { OLS }\end{array}$ & $\begin{array}{c}\text { (3) } \\
\text { Saved at formal } \\
\text { fin. institution } \\
\text { OLS }\end{array}$ & $\begin{array}{c}\text { (4) } \\
\text { Used debit card } \\
\text { in the last year } \\
\text { OLS }\end{array}$ \\
\hline Financial literacy & $\begin{array}{c}0.375 \\
(0.285)\end{array}$ & $\begin{array}{c}0.376 \\
(0.266)\end{array}$ & $\begin{array}{c}0.358 \\
(0.218)\end{array}$ & $\begin{array}{c}0.392 \\
(0.357)\end{array}$ \\
\hline Log GDP p.c. (PPP) & $\begin{array}{c}17.286^{* *} \\
(7.485)\end{array}$ & $\begin{array}{c}18.404 * * \\
(6.828)\end{array}$ & $\begin{array}{l}8.488^{*} \\
(4.551)\end{array}$ & $\begin{array}{c}15.841^{* *} \\
(7.627)\end{array}$ \\
\hline $\begin{array}{c}\text { Population share } \\
\text { between } 15-64\end{array}$ & $\begin{array}{c}0.670 \\
(0.603)\end{array}$ & $\begin{array}{l}-0.305 \\
(0.635)\end{array}$ & $\begin{array}{l}-0.535 \\
(0.609)\end{array}$ & $\begin{array}{l}-0.213 \\
(0.716)\end{array}$ \\
\hline $\begin{array}{r}\text { Secondary } \\
\text { education }\end{array}$ & $\begin{array}{c}0.114 \\
(0.217)\end{array}$ & $\begin{array}{c}0.188 \\
(0.186)\end{array}$ & $\begin{array}{c}0.072 \\
(0.141)\end{array}$ & $\begin{array}{c}0.296 \\
(0.219)\end{array}$ \\
\hline $\begin{array}{l}\text { Tertiary } \\
\text { education }\end{array}$ & $\begin{array}{l}-0.097 \\
(0.266)\end{array}$ & $\begin{array}{l}-0.238 \\
(0.259)\end{array}$ & $\begin{array}{c}0.149 \\
(0.179)\end{array}$ & $\begin{array}{c}0.148 \\
(0.277)\end{array}$ \\
\hline $\begin{array}{l}\text { Private credit to } \\
\text { GDP }\end{array}$ & $\begin{array}{c}0.172 * * * \\
(0.040)\end{array}$ & $\begin{array}{l}0.083^{*} \\
(0.048)\end{array}$ & $\begin{array}{l}0.110 * * \\
(0.044)\end{array}$ & $\begin{array}{l}-0.031 \\
(0.065)\end{array}$ \\
\hline $\begin{array}{r}\text { Bank branches } \\
\text { per } 1000 \text { km² }^{2}\end{array}$ & $\begin{array}{c}0.015 \\
(0.021)\end{array}$ & $\begin{array}{c}0.012 \\
(0.021)\end{array}$ & $\begin{array}{l}0.033^{*} \\
(0.016)\end{array}$ & $\begin{array}{c}0.012 \\
(0.025)\end{array}$ \\
\hline $\begin{array}{l}\text { Strength of legal } \\
\text { rights index }\end{array}$ & $\begin{array}{l}-0.720 \\
(0.667)\end{array}$ & $\begin{array}{l}-0.242 \\
(0.689)\end{array}$ & $\begin{array}{l}-0.298 \\
(0.694)\end{array}$ & $\begin{array}{c}0.000 \\
(0.844)\end{array}$ \\
\hline $\begin{array}{l}\text { Ease of doing } \\
\text { business index }\end{array}$ & $\begin{array}{c}0.006 \\
(0.104)\end{array}$ & $\begin{array}{l}-0.007 \\
(0.116)\end{array}$ & $\begin{array}{l}-0.021 \\
(0.061)\end{array}$ & $\begin{array}{c}0.039 \\
(0.143)\end{array}$ \\
\hline Power distance & $\begin{array}{c}0.117 \\
(0.117)\end{array}$ & $\begin{array}{l}-0.017 \\
(0.097)\end{array}$ & $\begin{array}{l}-0.069 \\
(0.099)\end{array}$ & $\begin{array}{l}-0.105 \\
(0.144)\end{array}$ \\
\hline Individualism & $\begin{array}{c}0.225 \\
(0.144)\end{array}$ & $\begin{array}{c}0.207 \\
(0.132)\end{array}$ & $\begin{array}{l}-0.105 \\
(0.097)\end{array}$ & $\begin{array}{c}0.315^{* *} \\
(0.153)\end{array}$ \\
\hline Masculinity & $\begin{array}{l}-0.091 \\
(0.081)\end{array}$ & $\begin{array}{c}-0.182 * * \\
(0.080)\end{array}$ & $\begin{array}{c}0.079 \\
(0.058)\end{array}$ & $\begin{array}{c}-0.265^{* *} \\
(0.099)\end{array}$ \\
\hline $\begin{array}{l}\text { Uncertainty } \\
\text { avoidance }\end{array}$ & $\begin{array}{c}0.043 \\
(0.091)\end{array}$ & $\begin{array}{l}-0.021 \\
(0.099)\end{array}$ & $\begin{array}{c}-0.294 * * * \\
(0.083)\end{array}$ & $\begin{array}{l}-0.101 \\
(0.135)\end{array}$ \\
\hline $\begin{array}{l}\text { Longterm } \\
\text { orientation }\end{array}$ & $\begin{array}{c}0.067 \\
(0.110)\end{array}$ & $\begin{array}{l}0.240^{*} \\
(0.124)\end{array}$ & $\begin{array}{l}0.171^{*} \\
(0.093)\end{array}$ & $\begin{array}{c}0.178 \\
(0.171)\end{array}$ \\
\hline Indulgence & $\begin{array}{l}-0.149 \\
(0.106)\end{array}$ & $\begin{array}{c}0.051 \\
(0.124)\end{array}$ & $\begin{array}{c}0.104 \\
(0.070)\end{array}$ & $\begin{array}{c}0.083 \\
(0.147)\end{array}$ \\
\hline Constant & $\begin{array}{c}-186.289 * * \\
(73.181) \\
\end{array}$ & $\begin{array}{c}-142.398 * \\
(72.088) \\
\end{array}$ & $\begin{array}{l}-33.998 \\
(34.062) \\
\end{array}$ & $\begin{array}{c}-133.964 * \\
(74.996) \\
\end{array}$ \\
\hline $\mathrm{R}^{2}$ & 0.87 & 0.88 & 0.87 & 0.86 \\
\hline Observations & 52 & 52 & 52 & 52 \\
\hline
\end{tabular}


Table A18: Financial literacy and financial inclusion incl. legal origin - OLS results

\begin{tabular}{|c|c|c|c|c|}
\hline & $\begin{array}{c}\text { (1) } \\
\text { Account } \\
\text { ownership } \\
\text { OLS }\end{array}$ & $\begin{array}{c}(2) \\
\text { Debit card } \\
\text { ownership } \\
\text { OLS }\end{array}$ & $\begin{array}{l}\text { (3) } \\
\text { Saved at formal } \\
\text { fin. institution } \\
\text { OLS }\end{array}$ & $\begin{array}{c}\text { (4) } \\
\text { Used debit card } \\
\text { in the last year } \\
\text { OLS }\end{array}$ \\
\hline Financial literacy & $\begin{array}{c}0.407 * * * \\
(0.147)\end{array}$ & $\begin{array}{l}0.397 * * \\
(0.159)\end{array}$ & $\begin{array}{l}0.415^{* * *} \\
(0.093)\end{array}$ & $\begin{array}{c}0.581^{* * *} \\
(0.163)\end{array}$ \\
\hline Log GDP p.c. (PPP) & $\begin{array}{c}13.474 * * * \\
(2.709)\end{array}$ & $\begin{array}{c}13.821 * * * \\
(2.461)\end{array}$ & $\begin{array}{c}6.356 * * * \\
(1.563)\end{array}$ & $\begin{array}{c}11.992 * * * \\
(2.329)\end{array}$ \\
\hline $\begin{array}{c}\text { Population share } \\
\text { between } 15-64\end{array}$ & $\begin{array}{l}-0.284 \\
(0.314)\end{array}$ & $\begin{array}{l}-0.498^{*} \\
(0.292)\end{array}$ & $\begin{array}{c}-0.577^{* * *} \\
(0.189)\end{array}$ & $\begin{array}{c}-0.684^{* *} \\
(0.318)\end{array}$ \\
\hline $\begin{array}{r}\text { Secondary } \\
\text { education }\end{array}$ & $\begin{array}{c}0.017 \\
(0.107)\end{array}$ & $\begin{array}{c}0.035 \\
(0.096)\end{array}$ & $\begin{array}{l}-0.051 \\
(0.066)\end{array}$ & $\begin{array}{l}-0.023 \\
(0.090)\end{array}$ \\
\hline $\begin{array}{l}\text { Tertiary } \\
\text { education }\end{array}$ & $\begin{array}{l}-0.139 \\
(0.151)\end{array}$ & $\begin{array}{c}0.091 \\
(0.149)\end{array}$ & $\begin{array}{c}0.037 \\
(0.102)\end{array}$ & $\begin{array}{l}0.300 * * \\
(0.139)\end{array}$ \\
\hline $\begin{array}{l}\text { Private credit to } \\
\text { GDP }\end{array}$ & $\begin{array}{c}0.114^{* * *} \\
(0.033)\end{array}$ & $\begin{array}{c}0.089 * * \\
(0.044)\end{array}$ & $\begin{array}{c}0.092 * * \\
(0.046)\end{array}$ & $\begin{array}{c}0.043 \\
(0.043)\end{array}$ \\
\hline $\begin{array}{r}\text { Bank branches } \\
\text { per } 1000 \mathrm{~km}^{2}\end{array}$ & $\begin{array}{c}0.076 * * * \\
(0.018)\end{array}$ & $\begin{array}{c}0.044 * * * \\
(0.017)\end{array}$ & $\begin{array}{c}0.051 * * \\
(0.023)\end{array}$ & $\begin{array}{c}0.036 * * \\
(0.018)\end{array}$ \\
\hline $\begin{array}{l}\text { Strength of legal } \\
\text { rights index }\end{array}$ & $\begin{array}{l}-0.095 \\
(0.486)\end{array}$ & $\begin{array}{l}-0.174 \\
(0.471)\end{array}$ & $\begin{array}{l}-0.104 \\
(0.374)\end{array}$ & $\begin{array}{c}0.326 \\
(0.499)\end{array}$ \\
\hline $\begin{array}{l}\text { Ease of doing } \\
\text { business index }\end{array}$ & $\begin{array}{l}-0.089 * \\
(0.051)\end{array}$ & $\begin{array}{l}-0.070 \\
(0.052)\end{array}$ & $\begin{array}{l}-0.023 \\
(0.037)\end{array}$ & $\begin{array}{l}-0.043 \\
(0.057)\end{array}$ \\
\hline $\begin{array}{c}\text { Scandinavian } \\
\text { legal origin }\end{array}$ & $\begin{array}{l}-5.831 \\
(5.798)\end{array}$ & $\begin{array}{l}13.743^{*} \\
(7.115)\end{array}$ & $\begin{array}{l}8.914^{*} \\
(5.063)\end{array}$ & $\begin{array}{l}22.670 * * * \\
(8.325)\end{array}$ \\
\hline French legal origin & $\begin{array}{c}-11.741 * * * \\
(3.334)\end{array}$ & $\begin{array}{l}-2.332 \\
(2.987)\end{array}$ & $\begin{array}{c}-8.222 * * * \\
(2.060)\end{array}$ & $\begin{array}{l}1.957 \\
(2.878)\end{array}$ \\
\hline German legal origin & $\begin{array}{c}2.216 \\
(4.239)\end{array}$ & $\begin{array}{c}11.528^{* *} \\
(4.453)\end{array}$ & $\begin{array}{l}-1.417 \\
(3.394)\end{array}$ & $\begin{array}{l}10.155^{*} \\
(5.169)\end{array}$ \\
\hline Constant & $\begin{array}{l}-59.477 * * \\
(25.634)\end{array}$ & $\begin{array}{c}-74.951 * * * \\
(25.039)\end{array}$ & $\begin{array}{l}-12.301 \\
(18.404)\end{array}$ & $\begin{array}{c}-69.413^{* *} \\
(30.602)\end{array}$ \\
\hline $\mathrm{R}^{2}$ & 0.84 & 0.84 & 0.78 & 0.80 \\
\hline Observations & 118 & 118 & 118 & 118 \\
\hline
\end{tabular}

Notes: The table reports OLS regression results. Robust standard errors in parentheses. British legal origin is the reference category for the different legal origin dummy variables. ${ }^{* *}, * *$ and $*$ denote significance at the $1 \%, 5 \%$ and $10 \%$ levels, respectively. 


\section{(1) \\ (2) \\ (3)}

(4)

Account Debit card ownership ownership
Saved at Used debit formal fin. $\quad$ card in last institution year

\begin{tabular}{lcccc}
\hline Financial literacy & $0.537^{* * *}$ & $0.379^{* * *}$ & $0.441^{* * *}$ & $0.418^{* * *}$ \\
& $(0.130)$ & $(0.138)$ & $(0.073)$ & $(0.120)$ \\
Log GDP p.c. (PPP) & $0.124^{* * *}$ & $0.146^{* * *}$ & $0.068^{* * *}$ & $0.139^{* * *}$ \\
& $(0.023)$ & $(0.023)$ & $(0.017)$ & $(0.024)$ \\
Population share & $-0.529^{*}$ & -0.307 & $-0.398^{* *}$ & -0.340 \\
between 15-64 & $(0.290)$ & $(0.262)$ & $(0.202)$ & $(0.242)$ \\
Secondary education & 0.032 & 0.076 & -0.044 & 0.048 \\
& $(0.089)$ & $(0.090)$ & $(0.073)$ & $(0.085)$ \\
Tertiary education & -0.063 & -0.055 & -0.078 & 0.047 \\
& $(0.125)$ & $(0.126)$ & $(0.096)$ & $(0.110)$ \\
Private credit to GDP & $0.165^{* * *}$ & $0.074 * *$ & $0.086 * * *$ & 0.021 \\
& $(0.035)$ & $(0.037)$ & $(0.032)$ & $(0.026)$ \\
Bank branches per 1000 km ${ }^{2}$ & $0.001^{* *}$ & 0.000 & $0.000 *$ & 0.000 \\
& $(0.000)$ & $(0.000)$ & $(0.000)$ & $(0.000)$ \\
Strength of legal rights index & 0.005 & 0.001 & 0.001 & 0.002 \\
& $(0.005)$ & $(0.005)$ & $(0.004)$ & $(0.004)$ \\
Ease of doing business index & -0.001 & $-0.001^{*}$ & -0.000 & -0.001 \\
& $(0.000)$ & $(0.000)$ & $(0.000)$ & $(0.001)$ \\
\hline Observations & 119 & 119 & 119 & 119 \\
\hline
\end{tabular}

Notes: The table reports fractional probit regression results. Robust standard errors are shown in parentheses. The outcome variables are the proportion of people over the age of 15 that have a bank account or own a debit card, proportion of people that saved at a formal financial institution and the proportion of people that used their debit card during the last year. ${ }^{* * *}, * *$ and $*$ denote significance at the $1 \%, 5 \%$ and $10 \%$ levels, respectively. 
Table A20: Financial literacy and access and use - quantile regressions

\begin{tabular}{|c|c|c|c|c|}
\hline & $\begin{array}{c}\text { (1) } \\
\text { Account } \\
\text { ownership }\end{array}$ & $\begin{array}{c}\text { (2) } \\
\text { Debit card } \\
\text { ownership }\end{array}$ & $\begin{array}{l}\text { (3) } \\
\text { Saved at a } \\
\text { formal fin. } \\
\text { institution }\end{array}$ & $\begin{array}{c}\text { (4) } \\
\text { Used debit } \\
\text { card in the } \\
\text { last year }\end{array}$ \\
\hline \multicolumn{5}{|l|}{$25^{\text {th }}$ quantile } \\
\hline Financial literacy & $\begin{array}{l}0.396 * \\
(0.204)\end{array}$ & $\begin{array}{l}0.592 * * \\
(0.256)\end{array}$ & $\begin{array}{c}0.386 * * \\
(0.150)\end{array}$ & $\begin{array}{l}0.540 * * \\
(0.221)\end{array}$ \\
\hline Constant & $\begin{array}{l}-66.842 \\
(42.440)\end{array}$ & $\begin{array}{c}-100.718^{* *} \\
(41.864)\end{array}$ & $\begin{array}{c}-3.422 \\
(27.645)\end{array}$ & $\begin{array}{l}-61.575^{*} \\
(35.337)\end{array}$ \\
\hline Control variables & yes & yes & yes & yes \\
\hline \multicolumn{5}{|l|}{$50^{\text {th }}$ quantile } \\
\hline Financial literacy & $\begin{array}{c}0.456 * * * \\
(0.155)\end{array}$ & $\begin{array}{c}0.529 * * * \\
(0.197)\end{array}$ & $\begin{array}{c}0.507 * * * \\
(0.131)\end{array}$ & $\begin{array}{c}0.784^{* * *} \\
(0.176)\end{array}$ \\
\hline Constant & $\begin{array}{l}-54.805 \\
(36.906)\end{array}$ & $\begin{array}{c}-88.692 * * * \\
(31.442)\end{array}$ & $\begin{array}{l}-28.256 \\
(29.479)\end{array}$ & $\begin{array}{l}-19.421 \\
(33.038)\end{array}$ \\
\hline Control variables & yes & yes & yes & yes \\
\hline \multicolumn{5}{|l|}{$75^{\text {th }}$ quantile } \\
\hline Financial literacy & $\begin{array}{c}0.272 \\
(0.200)\end{array}$ & $\begin{array}{c}0.649 * * * \\
(0.196)\end{array}$ & $\begin{array}{c}0.599 * * * \\
(0.163)\end{array}$ & $\begin{array}{c}0.670 * * * \\
(0.211)\end{array}$ \\
\hline Constant & $\begin{array}{l}-66.284 * \\
(36.337)\end{array}$ & $\begin{array}{l}-57.808 \\
(38.125)\end{array}$ & $\begin{array}{l}-27.485 \\
(31.426)\end{array}$ & $\begin{array}{l}-44.462 \\
(38.012)\end{array}$ \\
\hline Control variables & yes & yes & yes & yes \\
\hline Observations & 119 & 119 & 119 & 119 \\
\hline Model deg. of freedom & 30 & 30 & 30 & 30 \\
\hline Degrees of freedom & 109 & 109 & 109 & 109 \\
\hline No. of replications & 500.00 & 500.00 & 500.00 & 500.00 \\
\hline $\mathrm{q} 1=0.25$ & 0.25 & 0.25 & 0.25 & 0.25 \\
\hline $\begin{array}{l}\text { Raw sum of deviations } \\
\text { (q1) }\end{array}$ & 1137.25 & 994.79 & 528.35 & 763.57 \\
\hline $\begin{array}{l}\text { Min sum of } \\
\text { deviations(q1) }\end{array}$ & 476.05 & 466.23 & 343.53 & 454.20 \\
\hline $\mathrm{q} 2=0.5$ & 0.50 & 0.50 & 0.50 & 0.50 \\
\hline $\begin{array}{l}\text { Raw sum of deviations } \\
\text { (q2) }\end{array}$ & 1577.54 & 1501.39 & 836.84 & 1297.54 \\
\hline $\begin{array}{l}\text { Min sum of } \\
\text { deviations(q2) } \\
\text { q3 }=0.75\end{array}$ & 586.93 & 573.86 & 441.79 & 573.61 \\
\hline Raw sum of deviations & 1176.84 & 1261.57 & 812.80 & 1263.94 \\
\hline $\begin{array}{l}\text { Min sum of } \\
\text { deviations(q3) }\end{array}$ & 472.81 & 445.88 & 345.09 & 447.01 \\
\hline
\end{tabular}




\begin{tabular}{|c|c|c|c|c|}
\hline & $\begin{array}{c}\text { (1) } \\
\text { Account } \\
\text { ownership }\end{array}$ & $\begin{array}{c}(2) \\
\text { Debit card } \\
\text { ownership }\end{array}$ & $\begin{array}{c}\text { (3) } \\
\text { Saved at } \\
\text { formal fin. } \\
\text { institution }\end{array}$ & $\begin{array}{c}\text { (4) } \\
\text { Used debit } \\
\text { card in the } \\
\text { last year }\end{array}$ \\
\hline Financial literacy & $\begin{array}{c}0.605 * * * \\
(0.166)\end{array}$ & $\begin{array}{c}0.623 * * * \\
(0.211)\end{array}$ & $\begin{array}{c}0.455 * * * \\
(0.127)\end{array}$ & $\begin{array}{c}0.780^{* * *} \\
(0.214)\end{array}$ \\
\hline Private credit to GDP & $\begin{array}{c}0.180^{* * *} \\
(0.045)\end{array}$ & $\begin{array}{c}0.118 * * \\
(0.049)\end{array}$ & $\begin{array}{c}0.085^{* *} \\
(0.040)\end{array}$ & $\begin{array}{c}0.053 \\
(0.045)\end{array}$ \\
\hline $\begin{array}{l}\text { Interaction financial literacy } \\
\text { and private credit to GDP }\end{array}$ & $\begin{array}{l}-0.008^{*} \\
(0.005)\end{array}$ & $\begin{array}{l}-0.006 \\
(0.005)\end{array}$ & $\begin{array}{c}0.005 \\
(0.004)\end{array}$ & $\begin{array}{c}-0.002 \\
(0.006)\end{array}$ \\
\hline Log GDP p.c. (PPP) & $\begin{array}{c}16.911 \text { *** } \\
(2.947)\end{array}$ & $\begin{array}{c}17.253 * * * \\
(3.015)\end{array}$ & $\begin{array}{c}6.712^{* * *} \\
(1.929)\end{array}$ & $\begin{array}{c}14.216^{* * *} \\
(2.870)\end{array}$ \\
\hline Population share between 15-64 & $\begin{array}{c}-0.982 * * \\
(0.419)\end{array}$ & $\begin{array}{c}-0.939 * * \\
(0.424)\end{array}$ & $\begin{array}{c}-0.664^{* *} \\
(0.327)\end{array}$ & $\begin{array}{c}-0.846 * * \\
(0.398)\end{array}$ \\
\hline Secondary education & $\begin{array}{c}0.013 \\
(0.135)\end{array}$ & $\begin{array}{c}0.061 \\
(0.137)\end{array}$ & $\begin{array}{c}-0.061 \\
(0.112)\end{array}$ & $\begin{array}{c}0.023 \\
(0.131)\end{array}$ \\
\hline Tertiary education & $\begin{array}{l}-0.101 \\
(0.151)\end{array}$ & $\begin{array}{l}-0.040 \\
(0.191)\end{array}$ & $\begin{array}{l}-0.054 \\
(0.132)\end{array}$ & $\begin{array}{c}0.157 \\
(0.193)\end{array}$ \\
\hline Bank branches per 1000 km² & $\begin{array}{c}0.038 \\
(0.041)\end{array}$ & $\begin{array}{c}0.011 \\
(0.044)\end{array}$ & $\begin{array}{c}0.082 * * \\
(0.036)\end{array}$ & $\begin{array}{c}0.007 \\
(0.054)\end{array}$ \\
\hline Strength of legal rights index & $\begin{array}{c}0.460 \\
(0.633)\end{array}$ & $\begin{array}{c}0.001 \\
(0.662)\end{array}$ & $\begin{array}{l}-0.148 \\
(0.458)\end{array}$ & $\begin{array}{c}0.242 \\
(0.634)\end{array}$ \\
\hline Ease of doing business index & $\begin{array}{c}-0.074 \\
(0.061)\end{array}$ & $\begin{array}{l}-0.087 \\
(0.064)\end{array}$ & $\begin{array}{c}-0.045 \\
(0.042)\end{array}$ & $\begin{array}{l}-0.063 \\
(0.069)\end{array}$ \\
\hline Constant & $\begin{array}{l}-34.784 \\
(29.625)\end{array}$ & $\begin{array}{l}-55.873^{*} \\
(28.752)\end{array}$ & $\begin{array}{c}7.249 \\
(19.436)\end{array}$ & $\begin{array}{l}-50.379 \\
(32.951)\end{array}$ \\
\hline $\mathrm{R}^{2}$ & 0.828 & 0.792 & 0.757 & 0.760 \\
\hline Observations & 93 & 93 & 93 & 93 \\
\hline
\end{tabular}

Notes: The table shows the effect of financial literacy, private credit to GDP and their interaction on different measures of financial inclusion, including access to and use of financial services. Numeracy levels among primary school children act as instrument for financial literacy. Robust standard errors in parentheses. The interacted variables were centered at their means which correspond to $57.31 \%$ of GDP for financial depth and $36.4 \%$ for financial literacy. ${ }^{* * *}$, $* *$ and $*$ denote significance at the $1 \%, 5 \%$ and $10 \%$ levels, respectively. 


\begin{tabular}{|c|c|c|c|c|}
\hline & $\begin{array}{c}\text { (1) } \\
\text { Account } \\
\text { ownership }\end{array}$ & $\begin{array}{c}(2) \\
\text { Debit card } \\
\text { ownership }\end{array}$ & $\begin{array}{c}\text { (3) } \\
\text { Saved at } \\
\text { formal fin. } \\
\text { institution }\end{array}$ & $\begin{array}{c}\text { (4) } \\
\text { Used debit } \\
\text { card in the } \\
\text { last year }\end{array}$ \\
\hline Financial literacy & $\begin{array}{c}0.475^{* * *} \\
(0.147)\end{array}$ & $\begin{array}{c}0.535 * * * \\
(0.174)\end{array}$ & $\begin{array}{c}0.533 * * * \\
(0.105)\end{array}$ & $\begin{array}{c}0.747 * * * \\
(0.173)\end{array}$ \\
\hline Bank branches per $1000 \mathrm{~km}^{2}$ & $\begin{array}{c}0.114 \\
(0.096)\end{array}$ & $\begin{array}{c}0.018 \\
(0.077)\end{array}$ & $\begin{array}{c}0.004 \\
(0.083)\end{array}$ & $\begin{array}{c}0.012 \\
(0.090)\end{array}$ \\
\hline $\begin{array}{l}\text { Interaction financial literacy } \\
\text { and bank branches per } 1000 \mathrm{~km}^{2}\end{array}$ & $\begin{array}{l}-0.008 \\
(0.009)\end{array}$ & $\begin{array}{c}0.001 \\
(0.008)\end{array}$ & $\begin{array}{c}0.009 \\
(0.011)\end{array}$ & $\begin{array}{l}-0.000 \\
(0.011)\end{array}$ \\
\hline Log GDP p.c. (PPP) & $\begin{array}{c}16.494 * * * \\
(2.977)\end{array}$ & $\begin{array}{l}16.919 * * * \\
(2.908)\end{array}$ & $\begin{array}{c}6.926 * * * \\
(1.941)\end{array}$ & $\begin{array}{c}14.094 * * * \\
(2.764)\end{array}$ \\
\hline Population share between 15-64 & $\begin{array}{c}-0.793 * * \\
(0.394)\end{array}$ & $\begin{array}{c}-0.746^{* *} \\
(0.380)\end{array}$ & $\begin{array}{c}-0.733^{* *} \\
(0.311)\end{array}$ & $\begin{array}{c}-0.778 * * \\
(0.365)\end{array}$ \\
\hline Secondary education & $\begin{array}{l}-0.030 \\
(0.137)\end{array}$ & $\begin{array}{c}0.021 \\
(0.132)\end{array}$ & $\begin{array}{l}-0.043 \\
(0.107)\end{array}$ & $\begin{array}{c}0.009 \\
(0.123)\end{array}$ \\
\hline Tertiary education & $\begin{array}{l}-0.127 \\
(0.188)\end{array}$ & $\begin{array}{l}-0.112 \\
(0.200)\end{array}$ & $\begin{array}{l}-0.077 \\
(0.166)\end{array}$ & $\begin{array}{c}0.134 \\
(0.204)\end{array}$ \\
\hline Private credit to GDP & $\begin{array}{c}0.128 * * * \\
(0.034)\end{array}$ & $\begin{array}{c}0.093 * * \\
(0.044)\end{array}$ & $\begin{array}{c}0.123 * * * \\
(0.045)\end{array}$ & $\begin{array}{c}0.043 \\
(0.047)\end{array}$ \\
\hline Strength of legal rights index & $\begin{array}{l}-0.066 \\
(0.581)\end{array}$ & $\begin{array}{l}-0.166 \\
(0.639)\end{array}$ & $\begin{array}{c}0.302 \\
(0.635)\end{array}$ & $\begin{array}{c}0.165 \\
(0.710)\end{array}$ \\
\hline Ease of doing business index & $\begin{array}{l}-0.088 \\
(0.054)\end{array}$ & $\begin{array}{l}-0.103^{*} \\
(0.059)\end{array}$ & $\begin{array}{l}-0.041 \\
(0.052)\end{array}$ & $\begin{array}{l}-0.068 \\
(0.066)\end{array}$ \\
\hline Constant & $\begin{array}{l}-44.095 \\
(27.741)\end{array}$ & $\begin{array}{c}-66.029 * * \\
(27.960)\end{array}$ & $\begin{array}{c}1.506 \\
(22.021)\end{array}$ & $\begin{array}{c}-54.379 * \\
(32.995)\end{array}$ \\
\hline $\mathrm{R}^{2}$ & 0.824 & 0.810 & 0.735 & 0.771 \\
\hline Observations & 93 & 93 & 93 & 93 \\
\hline
\end{tabular}

Notes: The table shows the effect of financial literacy, bank branch penetration and their interaction on different measures of financial inclusion, including access to and use of financial services. Numeracy levels among primary school children act as instrument for financial literacy. Robust standard errors in parentheses. The interacted variables were centered at their means which correspond to 22.44 branches per $1000 \mathrm{~km}^{2}$ and $36.4 \%$ for financial literacy. ${ }^{* * *}$, ** and * denote significance at the $1 \%, 5 \%$ and $10 \%$ levels, respectively. 
(1)

Account

ownership
(2)

Debit card

ownership
(3)

Saved at formal fin. in the last year institution

\begin{tabular}{lcccc} 
Financial literacy & $0.622^{* * *}$ & $0.557^{* * *}$ & $0.438^{* * *}$ & $0.618^{* * *}$ \\
& $(0.168)$ & $(0.204)$ & $(0.111)$ & $(0.204)$ \\
Log GDP p.c. (PPP) & $0.710^{* * *}$ & $0.818^{* * *}$ & 0.096 & $0.527 * * *$ \\
Interaction financial literacy & $(0.210)$ & $(0.169)$ & $(0.119)$ & $(0.155)$ \\
and log GDP p.c. (PPP) & -0.020 & -0.009 & $0.025^{* *}$ & 0.020 \\
Population share between 15-64 & $(0.014)$ & $(0.013)$ & $(0.010)$ & $(0.014)$ \\
& -0.192 & -0.198 & -0.388 & -0.124 \\
Secondary education & $(0.419)$ & $(0.366)$ & $(0.273)$ & $(0.370)$ \\
& 0.087 & 0.149 & 0.048 & 0.125 \\
Tertiary education & $(0.142)$ & $(0.135)$ & $(0.108)$ & $(0.119)$ \\
& -0.134 & -0.157 & -0.105 & -0.038 \\
Private credit to GDP & $(0.171)$ & $(0.226)$ & $(0.130)$ & $(0.221)$ \\
& $0.161 * * *$ & $0.107 * *$ & $0.114 * * *$ & 0.051 \\
Bank branches per 1000 km ${ }^{2}$ & $(0.031)$ & $(0.044)$ & $(0.037)$ & $(0.038)$ \\
& 0.046 & -0.005 & 0.051 & -0.027 \\
Strength of legal rights index & $(0.045)$ & $(0.056)$ & $(0.034)$ & $(0.058)$ \\
& -0.355 & -0.668 & -0.480 & -0.446 \\
Ease of doing business index & $(0.616)$ & $(0.585)$ & $(0.440)$ & $(0.508)$ \\
& $-0.156 * *$ & $-0.169 * * *$ & $-0.075 *$ & $-0.140 * *$ \\
Constant & $(0.061)$ & $(0.061)$ & $(0.042)$ & $(0.063)$ \\
& $71.212 * * *$ & $59.194^{* *}$ & $43.504 * *$ & 38.299 \\
& $(26.285)$ & $(23.990)$ & $(17.621)$ & $(28.092)$ \\
\hline $\mathrm{R}^{2}$ & & & & \\
Observations & 0.805 & 0.799 & 0.774 & 0.779 \\
\hline
\end{tabular}

Notes: The table shows the effect of instrumented financial literacy, log GDP per capita and their interaction on different measures of financial inclusion, including access to and use of financial services. Numeracy levels among primary school children act as instrument for financial literacy. Robust standard errors in parentheses. The interacted variables were centered at their means which correspond to about 6041.35 PPP USD for GDP per capita (reconverted to real values) and $36.4 \%$ for financial literacy. ${ }^{* * *}, * *$ and $*$ denote significance at the $1 \%, 5 \%$ and $10 \%$ levels, respectively. 
Average marginal effects of centered fin. lit. with $95 \%$ CIs - IV
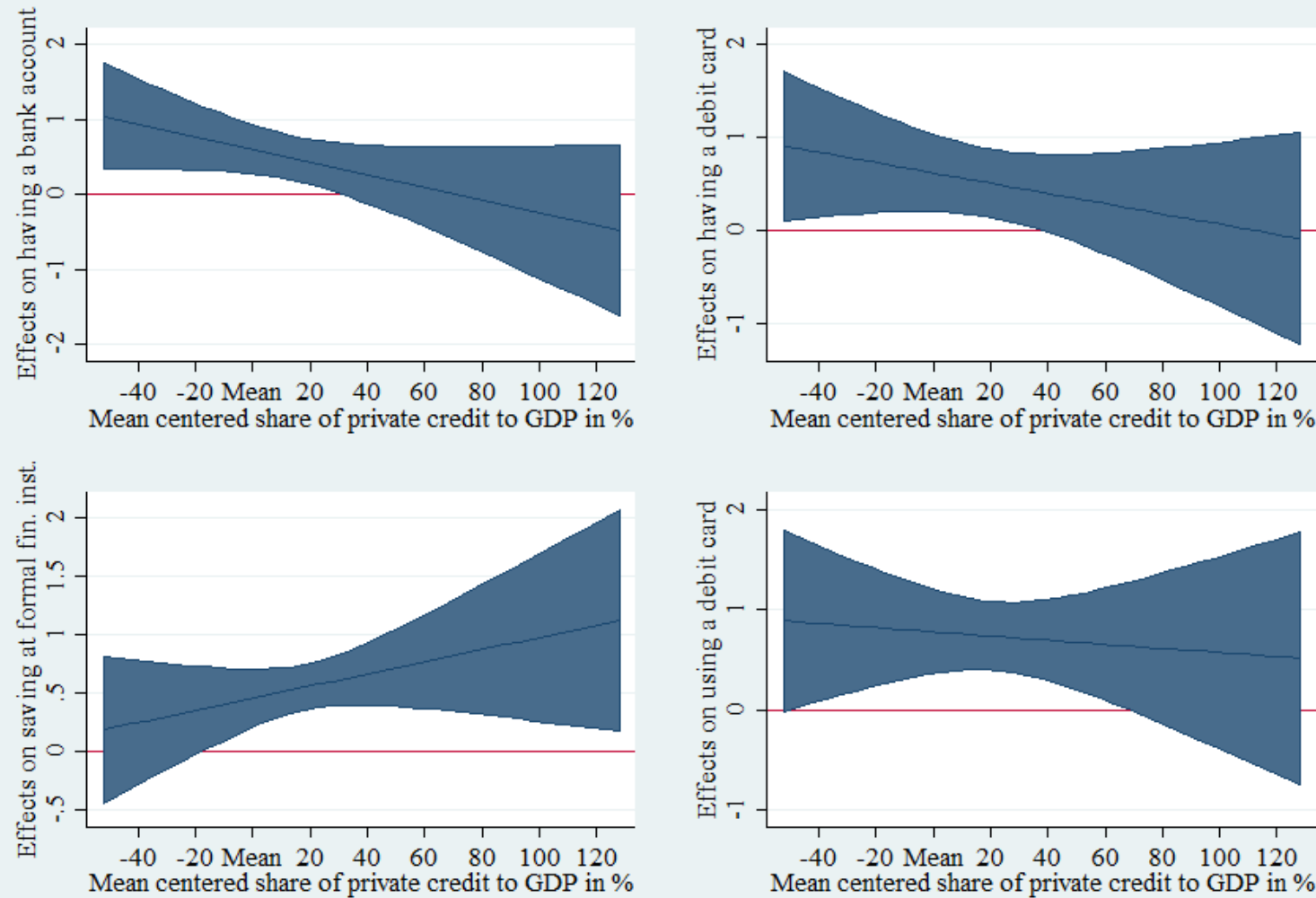

Figure A1: Average marginal effects of financial literacy on four measures of financial inclusion at different levels of private credit to GDP (IV) 
Average marginal effects of centered fin. lit. with $95 \%$ CIs - IV
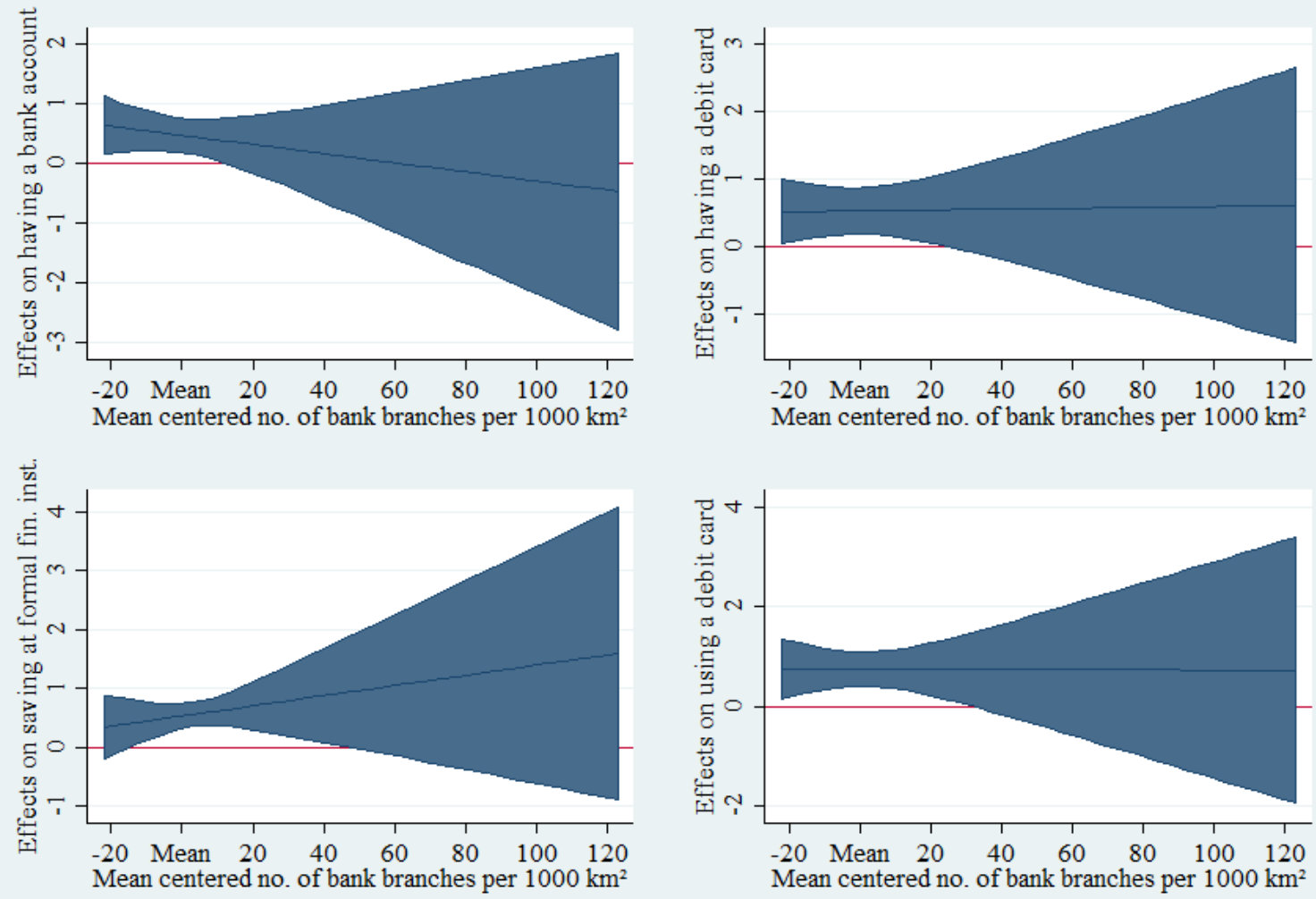

Figure A2: Average marginal effects of financial literacy on four measures of financial inclusion at different levels of bank branches per $1000 \mathbf{~ k m}^{2}$ (IV) 
Average marginal effects of centered fin. lit. with $95 \%$ CIs - IV
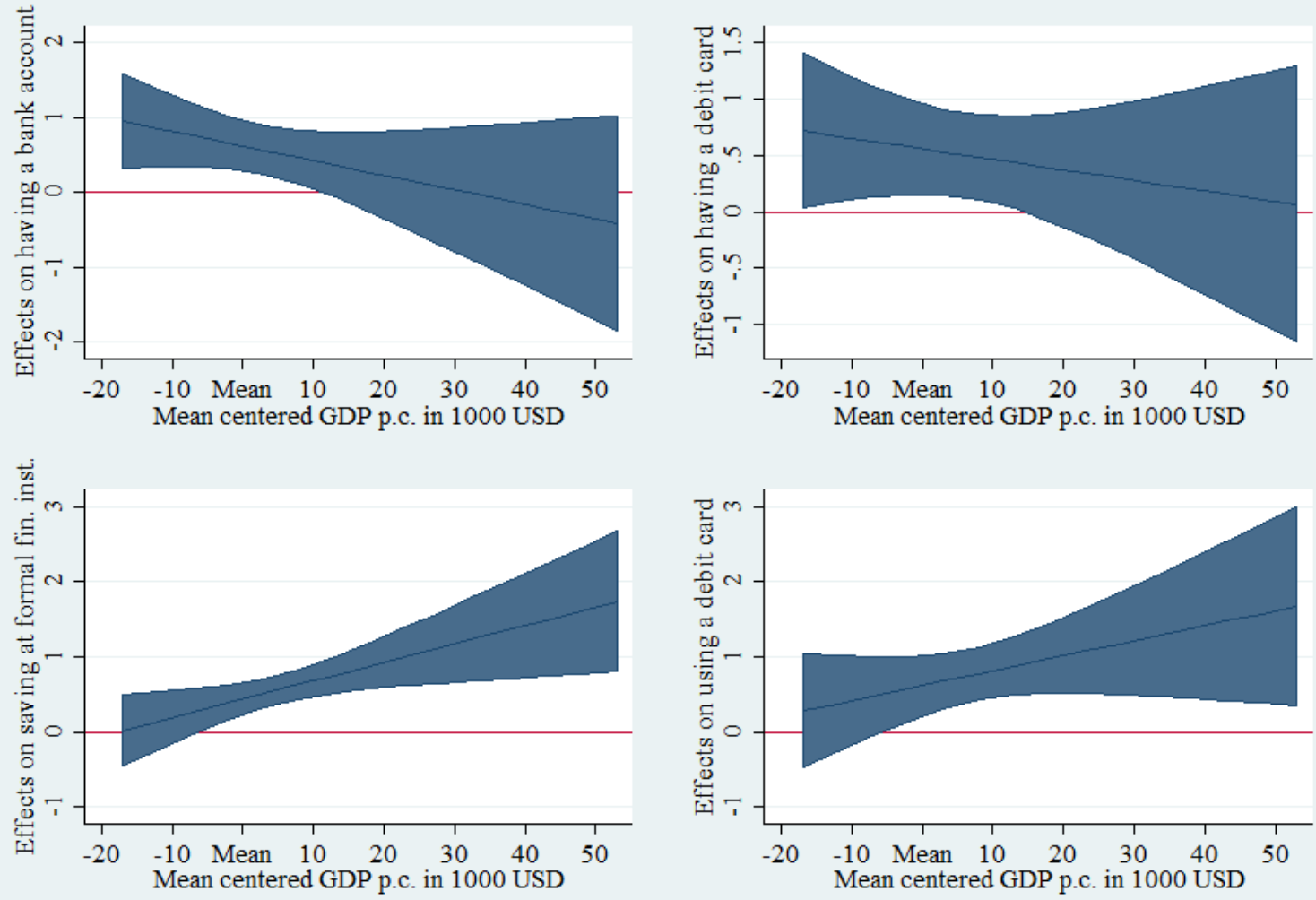

Figure A3: Average marginal effects of financial literacy on four measures of financial inclusion at different levels of GDP per capita (IV) 